\title{
Green War: An Assessment of the Environmental Law of International Armed Conflict
}

\author{
Michael N. Schmitt ${ }^{\dagger}$
}

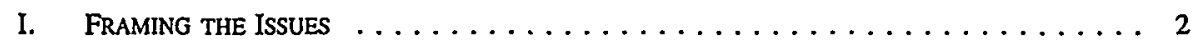

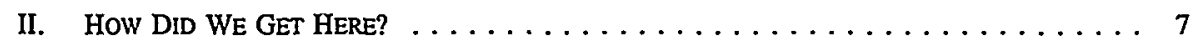

A. The Environment and Warfare Before Vietnam .............. 7

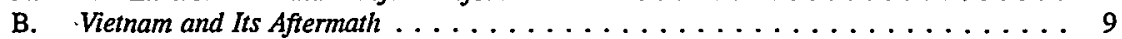

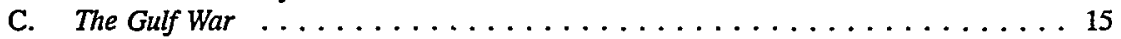

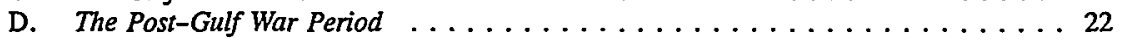

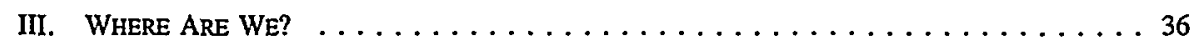

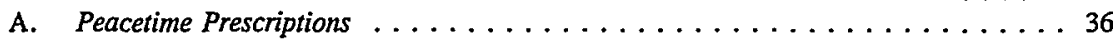

1. Applicability .......................... 37

2. Substantive Norms ..................... 41

B. Customary Jus in Bello . . . . . . . . . . . . . . . . . 51

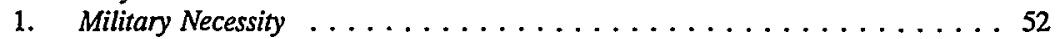

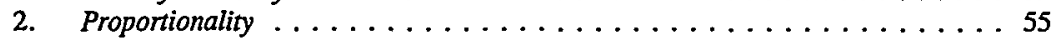

3. Humanity . ....................... 61

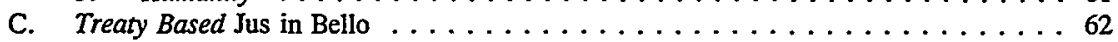

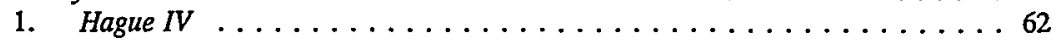

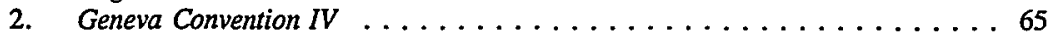

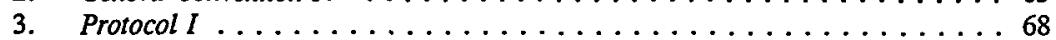

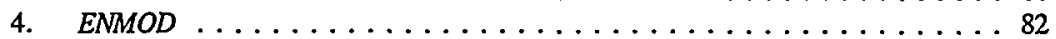

5. Miscellaneous Prescriptions .................. 85

D. Responsibility Under the Jus in Bello . . . . . . . . . . . . . . . . 90

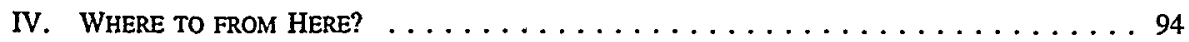

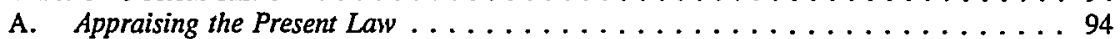

B. What Is To Be Done? ........................... 100

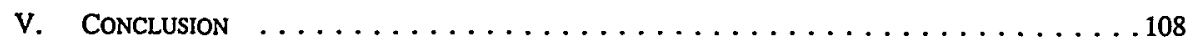

$\dagger$ Advanced Research Fellow, United States Naval War College; Lieutenant Colonel, United States Air Force. LL.M 1991, Yale Law School; J.D. 1984, University of Texas; M.A. 1996, Naval War College; M.A. (1983) and B.A. (1978), Southwest Texas State University. The views expressed in this Article are those of the author in his personal capacity and should not be construed as representing those of the Department of Defense, United States Air Force, or Naval War College. 
Victory smiles upon those who anticipate the changes in the character of war, not upon those who wait to adapt themselves after they occur.'

\section{FRAMING THE ISSUES}

As the twenty-first century approaches, the methods, means, and effects of warfare are in the midst of a profound revolution. ${ }^{2}$ This revolution is evident, for instance, in the new focus of the U.S. armed forces on military operations other than war (MOOTW) ${ }^{3}$ in revised tactics designed to exploit stealth technology, and in a probably healthy obsession with the potential for information warfare. ${ }^{4}$ One of the most visible aspects of this revolution is a growing interrelationship between war and the environment, reflected both in armed conflict's impact on nature and in the use of the environment as a tool of warfare. While these are not novel phenomena in war, the potential scope of damage and the next generation of environmental weapons that science is making possible are unprecedented. There is little question that this quantitative and qualitative evolution merits characterization as "revolutionary."

This Article identifies and assesses the law that might govern activities bearing on the environment during hostilities. ${ }^{5}$ Lack of consensus on the content of the relevant law highlights the importance of this task. Prior to considering the prescriptive environment proper, it is necessary to explore the genesis and evolution of the current norms. Therefore, Part II examines the history of environmental damage during warfare, as well as the legal responses thereto. A historical survey is an essential first step in any comprehensive legal analysis, for law is both contextual and directional. It is contextual in that it is understood and applied based upon the social, political, and economic environment in which it operates. ${ }^{6}$ This is certainly the case

1. THE COMMAND OF THE AIR 338 (Office of Air Force History ed., 1983) (quotation attributed to Air Marshall Guilio Douhet).

2. For an interesting discussion of what constitutes a "revolution in military affairs," see Andrew F. Krepinievich, Cavalry to Computer: 'The Pattern of Military Revolutions, in STRATEGY AND FORCE PLANNING 58 (Naval War College ed., 1995). Throughout this Article, the terms "armed conflict" and "war" will be used interchangeably. Some scholars draw a distinction between the two, reserving the term "war" for those situations in which a formal declaration has been made. This distinction serves little purpose given the scope and scale of post-World War II conflicts and the lack of a declaration of war in the vast majority of them.

3. For a basic description of MOOTW, see JOINT CHIEFS OF STAFF, DOCTRINE For JOINT OPERATIONS ch. V (Joint Publication 3-0, 1995).

4. Information warfare has generated a flurry of activity in the Department of Defense. For an introduction to the subject, see Martin C. Libicki, What Is Information Warfare?, STRATEGIC F., May 1995, at 1; see also JOINT CHIEFS OF STAFF, INFORMATION WARFARE: LEGAL, REGULATORY, POLICY AND ORGANIZATIONAL CONSIDERATIONS FOR ASSURANCE (Research Report for the Chief, Information Warfare Division-J6K, July 4, 1995).

5. I first addressed this topic in tentative form in a comment. See Michael N. Schmitt, The Environmental Law of War: An Invitation to Critical Reexamination, 7 U.S.A.F.A. J. LEGAL STUD. 237 (1996). Though parts of this Article draw directly on the previous piece, it builds on my initial thoughts and expands the focus of consideration beyond core jus in bello substantive prescriptions.

6. This contextuality is apparent in the growing willingness of the international community to subordinate sovereignty to humanitarian interests in the post-Cold War, post-bipolar environment. The humanitarian operations in Somalia, Iraq, or Bosnia would not have been possible had the Cold War continued. On contextuality and the use of force, see Michael N. Schmitt, The Resort to Force in International Law: Reflections on Positivist and Contextual Approaches, 37 A.F. L. REv. 105, 110-15 
with the environmental law of war, which is primarily the product of two historic events-Vietnam and the Gulf War. At the same time, law tends to be directional; it evolves over time in distinct directions. ${ }^{7}$ Seldom spontaneous or random, these trends are often identifiable and occasionally predictable. The environmental law of war demonstrates several trends, one of which - a growing tendency to value the environment for more than merely what it offers us-has enormous potential to complicate and transform the law.

Once context and direction are established, Part III proceeds to catalogue and analyze the current law pertaining to the environment. For analytical clarity, it is grouped into three categories: peacetime prescriptions, customary law, and treaties. The part begins by exploring whether peacetime environmental prescriptions remain intact during armed conflict, and, if so, between whom and in what circumstances. Since peacetime environmental law continues to evolve, it is less useful to catalogue substantive norms than to ascertain the criteria for their applicability during hostilities. Analysis of the law of war follows. Customary law, which lies at its core, is examined to determine when traditional norms can be interpreted as providing environmental safeguards. An evaluation of treaty law-not only the sparse collection of environment-specific provisions, but also its broader nonspecific components-completes the review of prescriptive norms.

Throughout Part III, one should bear in mind that the assorted relevant prescriptions do not operate autonomously; jurisprudential vacuums exist only in theory. Instead, the various components of the law, whether customary or treaty-based, operate together to create a prescriptive environment. It is that environment that bounds warfare. Thus, treaty provisions may be interpreted by resort to customary law principles; treaty law may be deemed declarative of customary law and thereby clarify it; customary law may fill voids in applicable conventions; or custom and treaty law may operate synergistically to create tiers of protection for the environment. ${ }^{8}$ Even when the law has been sorted out, it remains necessary to determine who has consented to be bound by what law in relation to whom. It is also necessary to ask how the

(1994).

7. An excellent example of this evolution of law is the erosion of neutral (as opposed to belligerent) interests in the law of naval warfare. The erosion has resulted from both technological advances in the means of warfare and the increasing interdependency of the international economy.

8. See infra Subsection III.C.3 (discussing Protocol D). For example, proportionality is a classic law of war principle intended to be codified in Protocol I. See Protocol Additional to the Geneva Conventions Relating to the Protection of Victims of International Armed Conflicts, June 8, 1977, U.N. Doc. A/32/144, 16 I.L.M. 1391 [hereinafter Protocol I]. Thus, its customary law meaning can be invoked in exploring the Protocol I restatement of the concept. On the other hand, the United States has not ratified Protocol I, but considers many of its provisions to be declarative of customary international law. See infra note 318 and accompanying text. Therefore, it remains a useful source for clarification of customary law principles. Furthermore, conventions are often drafted narrowly. Consider the Protocol I prohibitions on attacking dams, dikes, and nuclear power generating stations. See Protocol I, supra, art. 56. Its drafters debated whether this list is illustrative or exhaustive, ultimately deciding on the latter. However, this does not mean that other types of targets are fair game in article 56 situations. Customary principles such as proportionality and necessity will continue to govern such attacks. Moreover, the various types of law may intersect in terms of quantum of damage or nature of the target. This is particularly true in the environmental context, for some of the relevant conventional law has been criticized as setting an excessively high threshold for damage before a proscription applies. Protocol I is an excellent example. See infra note 353 and accompanying text. 
affected international actors understand the law and how they intend to implement its standards. In this regard, the law of war manuals that the world's militaries employ are particularly useful. Part III, therefore, discusses not only which norms govern damage to the environment during armed conflict, but also how they interact in theory and practice. It is in this dynamic that the drama of the law is to be found.

While Part III highlights various strengths and weaknesses of the prescriptive regime's individual components, Part IV assesses the current state of the law. As will be seen, most commentators judge the law to be adequate but fault lax enforcement and weak dissemination for the impunity with which rogue leaders have abused the environment in this decade. This Article tests their characterization both from the perspective of adequate environmental protection and from that of usable normative guidance for policymakers and warfighters. Ultimately, it concludes that, despite assertions to the contrary, the emperor is rather scantily clad. The relevant law is difficult to apply in practice, is definitionally flawed, and lacks internal coherence. Equally distressing is a growing tendency to view the environment as wholly distinct from human existence. This trend may lead us to sacrifice compelling human values on the altar of formalistic environmentalism.

Lest this criticism be labeled gratuitous, Part IV also suggests how the international community, and particularly the U.S. armed forces, should safeguard the environment during armed conflict. There could not be a more propitious time to consider the options, as the U.S. military is currently drafting a new multi-service law of war manual. Since many of the world's armed forces look to the United States in military affairs, this manual is destined to be enormously influential on an international scale. Therefore, to help translate theory into reality, Part IV outlines the environmental factors that the drafters of the new U.S. law of war manual should consider.

Before setting off on these endeavors, however, it is perhaps useful to delineate the boundaries of my inquiry. First, this Article does not analyze arms limitation, arms proliferation, and test ban treaty regimes. ${ }^{9}$ The issue at hand is one of use, not possession. An assessment of environmental prescriptions operative during noninternational armed conflict is likewise absent. ${ }^{10}$ My goal is to consider only those hostilities that are truly

9. Many of these treaties bear on the relationship between war and the environment because they limit or prohibit environmentally destructive weapons. See, e.g., Treaty on the Principles Governing the Activities of States in the Exploration and Use of Outer Space, Including the Moon and Other Celestial Bodies, Jan. 27, 1967, art. IV, 18 U.S.T. 2410, 610 U.N.T.S. 205 (banning placement in orbit of nuclear weapons or weapons of mass destruction); Treaty Banning Nuclear Weapons Tests in the Atmosphere, in Outer Space and Under Water, Aug. 5, 1963, art. 1, 14 U.S.T. 1313, 480 U.N.T.S. 43; Antarctic Treaty, June 23, 1961, art. I, para. 1, 12 U.S.T. 794, 402 U.N.T.S. 71 (prohibiting any weapons testing in Antarctica).

10. The distinction between international and noninternational armed conflicts is not always clear. Protocol II Additional to the Geneva Conventions defines noninternational armed conflict as armed conflicts ... . which take place in the territory of a [party to the Convention] between its armed forces and dissident armed forces or other organized armed groups which, under responsible command, exercise such control over a part of its territory as to enable them to carry out sustained and concerted military operations.

Addition to Protocol II, art. 1, para. 1, U.N. Doc. A/32/144, Annex II (1977), reprinted in 16 I.L.M. 1442,1443 [hereinafter Protocol II]. International armed conflict is that which arises between states (or 
international in scope. Furthermore, this Article does not address the jus ad bellum issue of when an "attack" on, or use of, the environment constitutes a resort to force in violation of the U.N. Charter. ${ }^{11}$ Instead, analysis of the jus in bello (i.e., how, not when, force may be employed) dominates the study. Finally, this Article makes no attempt to evaluate comprehensively the legality of individual environmentally harmful episodes of warfare; analysis and commentary focus instead on the law itself. ${ }^{12}$

Clarifying definitions, particularly that of the term "environment," is equally important. As used here, "environment" indicates those conditions, circumstances, substances, and organisms that affect the global ecosystem. Physical phenomena such as weather and the permeability of the ozone layer are examples of "conditions," whereas the course of a river and the existence of a lake illustrate the term "circumstances." Food, timber, soil, water, and oil exemplify "substances," and "organisms" include both plant and animal life. The concept of the "environment" also extends to usability. For example, spreading mines or bomblets through an area can render it unusable; such denial of use is the functional equivalent of damage.

While the need to define the environment before evaluating prescriptions governing harm to it is self-evident, far less obvious is the importance of identifying the motivations underlying environmental protection. The issue has been addressed only sparingly in the literature, primarily within governmental fora and at conferences. Interestingly, those who consider it tend to arrive at very different conclusions regarding the law's adequacy than from most of their colleagues. ${ }^{13}$. Therefore, it is useful to alert the reader early on to the

other subjects of international law). See, e.g., Geneva Convention for the Amelioration of the Condition of the Wounded and Sick in Armed Forces in the Field, Aug. 12, 1949, art. 2, 6 U.S.T. 3114, 75 U.N.T.S. 31 (" [T] he present Convention shall apply to all cases of declared war or of any other armed conflict which may arise between two or more of the High Contracting Parties, even if a state of war is not recognized by one of them."); Geneva Convention for the Amelioration of the Condition of the Wounded, Sick and Shipwrecked Members of the Armed Forces at Sea, Aug. 12, 1949, art. 2, 6 U.S.T. 3217, 75 U.N.T.S. 85 (same); Geneva Convention Relative to the Treatment of Prisoners of War, Aug. 12, 1949, art. 2, 6 U.S.T. 3316, 75 U.N.T.S. 135 (same); Geneva Convention Relative to the Protection of Civilian Persons in Time of War, Aug. 12, 1949, art. 2, 6 U.S.T. 3516, 75 U.N.T.S. 287 (same) [hereinafter Geneva Convention IV]. Additional Protocol I, which supplements the Geneva Conventions with regard to international armed conflict, simply refers back to the common article 2 of the Geneva Conventions. See Protocol I, supra note 8, art. 1, para. 3. In a somewhat controversial provision, Protocol I includes as intermational armed conflicts "armed conflicts in which peoples are fighting against colonial domination and alien occupation and against racist regimes in the exercise of their right of selfdetermination." Id. art. 1, para. 4. Note that "internal disturbances and tensions, such as riots, isolated and sporadic acts of violence and other acts of a similar nature" are not armed conflict-either international or noninternational. See Protocol II, supra, art. 1, para. 2.

11. Article 2(4) of the U.N. Charter provides that "[a]ll Members shall refrain in their international relations from the threat or use of force against the territorial integrity or political independence of any state, or in any other manner inconsistent with the Purposes of the United Nations." U.N. CHARTER art. 2, para. 4. The Charter does authorize the use of force when pursuant to a Security Council determination that it is "necessary to maintain or restore international peace and security," id. art. 42, or required in individual or collective self-defense, see $i d$. art. 51.

12. For instance, the question is not whether the Iraqis violated the law of armed conflict, but rather what law governs the types of activities in which they engaged.

13. The most notable example is Wil Verwey, Chairman of the National University of Gronigen (Netherlands) Department of International and Constitutional Law. See, e.g., Wil D. Verwey, Observations on the Legal Protection of the Environment in Times of International Armed Conflict, in 1994 HAGUE Y.B. INT'L L. 35, 49 [hereinafter Verwey, Observations]; Wil D. Verwey, Protection of the 
effects of this distinction.

There are basically two approaches: "utilitarian" and "intrinsic worth." 14 The prevailing one values the environment for what it offers humankind-food, shelter, fuel, and clothing, for example. This anthropocentric approach focuses on the environment's ability to make life possible-and to take it away. Beyond providing survival benefits, the environment merits protection because of its impact on the quality of human life. For instance, natural preserves or endangered species must be safeguarded lest we be deprived of their aesthetic value. Reduced to basics, anthropocentrism displays a strong utilitarian flavor.

On the other hand, the environment can be viewed as possessing intrinsic value, that is, value that is independent of the uses for which human beings may exploit it. This value is not in lieu of anthropocentric value but in addition to it. For intrinsic valuation advocates, determining the environment's contribution to human existence is only half the story when assessing whether its destruction is justifiable and lawful. Calculating the intrinsic value of the environment's damaged component is equally necessary. Of course, intrinsic value measurements are inherently difficult since the point of departure is not the human self. Proponents, however, might argue that through consideration of such factors as ecosystem function or species regeneration capacity, intrinsic value is sufficiently discernible to merit inclusion in legal formulae.

The distinction between anthropocentric and intrinsic value is, borrowing from the law of evidence, both an issue of weight and one of admissibility. At heart, laws of war are often about balancing competing interests. Whether one operates from within an anthropocentric or intrinsic value cognitive prism determines the relative weight accorded competing interests. An even more basic question is whether intrinsic valuation has a place in the law of war at all-whether it is admissible, if you will. Thus, this study searches for evidence of the distinction and, if one exists, its implications. It concludes by evaluating the appropriateness of any trends identified.

It might be assumed that the anthropocentric/intrinsic divide, or the environment and warfare issue more generally, is highly politicized. ${ }^{15}$ In fact, there are some predictable distinctions among those who have taken positions on the matter. For instance, organizations such as Greenpeace tend to advocate a higher standard of environmental protection than do others. However, all concerned basically agree that there must be heightened

\footnotetext{
Environment in Times of Armed Conflict: In Search of a New Legal Perspective, 8 LEIDEN J. INT'L L. 7 , 39-40 (1995) [hereinafter Verwey, Protection]; Wil D. Verwey, Protection of the Environment in Times of Armed Conflict: Do We Need Additional Rules?, Paper Presented at the Symposium on the Protection of the Environment During Armed Conflict and Operations Other Than War (Sept. 1995) [hereinafter Verwey, Additional Rules]. The last paper and all others presented at the Symposium are forthcoming in PROTECTION OF THE ENVIRONMENT DURING ARMED CONFLICT \& OTHER MILITARY OPERATIONS (Naval War College International Law Studies No. 69) (Richard Grunawalt et al. eds., forthcoming 199) [hereinafter NWC SYMPOSIUM PAPERS].

14. For an interesting discussion of these two approaches, see Merrit P. Drucker, The Military Commander's Responsibility for the Environment, 11 ENVTL. ETHICS 135, 136-40 (1989).

15. Peacetime international environmental law is much more politicized. For instance, lesser developed states often oppose constraints on industrialization that might retard development. See infra note 215 and accompanying text.
} 
environmental safeguards during armed conflict. Given this agreement, one aspect of the debate centers on how best to effect those safeguards-through new law or through improved enforcement mechanisms. The debate over the anthropocentric/intrinsic division is much more fundamental; it centers on how to balance worthy values that sometimes conflict.

This debate cuts across traditional political lines and international boundaries. For example, the International Committee of the Red Cross (ICRC), an organization dedicated to mitigating the impact of warfare on humanity, finds itself allied with hard-core warfighters in opposing any movement away from anthropocentrism. The ICRC fears that applying the intrinsic value approach may decrease human protection, whereas warfighters tend to be concerned that it may distort proportionality calculations and thereby immunize valid military objectives. Nevertheless, that the ICRC and warfighters arrive at similar conclusions indicates that political dimensions to the issue have minimal practical effect. Paradoxically, the politicization that does occur is often the result of ideological prejudices. Thus an organization like Greenpeace evokes an almost visceral response from some parties that is entirely disproportionate to the actual difference in their respective views on the subject. Given the identity of the participants, observers expect politicization of the issues. In fact, the issues here are often less politicized than the participants.

With the boundaries of inquiry set, and with the reader sensitized to the role of cognitive perspectives, analysis may proceed. As it does, reflect on the following pervasive questions: Does the law adequately protect the environment during international armed conflict? If so, does the law sufficiently preserve and foster important human interests? Does the present law facilitate the balancing of environmental interests with other interests during warfare? Does it adequately deter unacceptable environmental damage during warfare, and, if not, why not? To what extent are the prescriptions sufficiently precise to guide policymakers and warfighters? Finally, if the law falls short, how should its shortfalls be remedied? Bearing these questions in mind, I now turn to the historical context that informs the environmental law of war.

\section{HOW DID We GET HERE?}

\section{A. The Environment and Warfare Before Vietnam}

That war damages the environment is a truism. So, too, can the forces of nature serve as a powerful weapon during war. ${ }^{16}$ In the seventeenth century, for example, the Dutch destroyed dikes to flood their lowlands and stem the advance of their enemies, thereby devastating vast tracts of farmland. In 1938, during the second Sino-Japanese War, the Chinese adopted an identical tactic

16. An extensive discussion of the history of the environmental effects of warfare can be found in ARTHUR H. WESTING, WARFARE IN A FRAGILE WORLD: THE MilitaRY IMPACT ON THE HuMAN ENVIRONMENT (1980). In particular, refer to table 1.2, which gives a selection of "ecologically disruptive wars." Id. at 14-19 tbl.1.2. 
when they destroyed the Huayuankow dike on the Yellow River to halt the Japanese invaders. Although a short-term military success, the operation killed thousands of civilians and flooded millions of acres of cultivated land. In the next decade, the Germans employed a similar technique by flooding a number of areas in the Netherlands to slow the Allied advance eastward. The European theater also witnessed repeated attacks on hydroelectric dams. To cite only one example, raids on the Möhne and Eder dams in May 1943, although effectively depriving the Ruhr industrial complex of water and power, killed more than 1300 civilians and shut off drinking water and energy to the four million Germans in the region. Dam attacks continued during the Korean and Vietnam conflicts. ${ }^{17}$

This century witnessed the first major environmental damage caused by the destruction of oil facilities. In a notable chapter of the First World War, British Colonel Norton Griffiths destroyed Romanian oil fields, the richest in Europe, to prevent them from falling into enemy hands when the Central Powers invaded. ${ }^{18}$ Romanian oil was again a target in the Second World War. Most noteworthy were the 1943 air raids on the oil producing center at Ploesti. Memorable for the feats of airmanship involved in the fifteen-hundred mile flight, much of it through enemy fighter cover, the raids significantly damaged refineries and oil tanks fueling the Reich's war machine. As might be imagined, all such attacks wrought extensive environmental damage.

Of course, it was in the Second World War that the only instances in history of wartime environmental destruction by nuclear weapons took place when U.S. aircraft bombed Hiroshima and Nagasaki in August 1945. Tens of thousands died immediately, with thousands of others doomed to suffer the effects of radiation for decades to come. The target area was reduced to a virtual wasteland. ${ }^{19}$ That those weapons are dwarfed by modern nuclear

17. The foregoing events are described in many sources. Of particular note is their inclusion in the ICRC Commentary to article 56 of Protocol I. See INTERNATIONAL COMM. OF THE RED CROSS, COMMENTARY ON THE ADDITIONAL PROTOCOLS OF 8 JUNE 1977 TO THE GENEVA CONVENTIONS OF 12; AUGUST 1949, at 667 (Yves Sandoz et al. eds., 1987) [hereinafter ICRC COMMENTARY]. The raid on the Mõhne dam was poignantly described by Wing Commander Guy Penrose Gibson of the RAF:

As Gibson flew his Lancaster up and down the dam, he saw the water of the dammed lake rising "like stirred porridge in the moonlight, rushing through a great breach." A few minutes later, he reported: "The valley was beginning to fill with fog and . . . we saw cars speeding along the roads in front of this great wave of water which was chasing them. . . . I saw their headlights burning and I saw water overtake them, wave by wave, and then the color of the headlights underneath the water changing from light blue to green, from green to dark purple until there was no longer anything except the water bouncing up and down."

THE AMERICAN HeRITAGE History OF WORLD WAR II, at 418 (David G. McCullough ed., 1966).

18. See Adam Roberts, Environmental Issues in International Armed Conflict: The Experience of the 1991 Gulf War, Paper Presented at the Symposium on the Protection of the Environment During Armed Conflict and Operations Other Than War in NWC SYMPOSIUM PAPERS, supra note 13 (manuscript at 5, on file with The Yale Journal of International Law) (citing C.R.M.F. CRUTTWELL, A HISTORY OF THE GREAT WAR, 1914-1918, at 297-98 (1934)).

19. One eyewitness of the explosion in Hiroshima described the destruction:

Within a few seconds the thousands of people in the streets and the gardens in the center of the town were scorched by a wave of searing heat. Many were killed instantly, others lay writhing on the ground, screaming in agony from the intolerable pain of their burns. Everything standing upright in the way of the blast, walls, houses, factories, and other buildings, was annihilated. ... Horses, dogs, and cattle suffered the same fate as human beings. Every living thing was petrified in an attitude of indescribable suffering. Even the 
capabilities emphasizes the environmental apocalypse that their widespread use would ensure today.

Despite the destructiveness of such events, the international community paid scant attention to their environmental consequences. The limited expressions of concern were from a purely anthropocentric perspective, as demonstrated by the failure to mention the environment in the four Geneva Conventions promulgated in the immediate aftermath of World War II. In part, this may have been because, as Geoffrey Best has perceptively noted, until the Second World War, man's destructive capabilities primarily threatened the anthropogenic environment. ${ }^{20}$ It was also surely the result of a failure to understand the complex interrelationships between human activities and the environment, the fragility of the environment, or even its finite nature. Until the war in Vietnam, whatever protection the environment enjoyed under international law was purely coincidental.

\section{B. Vietnam and Its Aftermath}

During the Vietnam conflict, the environment began to play a prominent role in considerations of warfare's means and methods. ${ }^{21}$ For military planners, Vietnam presented unique challenges. United States and South Vietnamese forces faced both regular North Vietnamese Army troops who had infiltrated the South and indigenous guerrilla units-the Viet Cong-supplied via a complex network of trails from the North and from Cambodian and Laotian sanctuaries. Among the factors that contributed to the Communist forces' ultimate success was an ability to blend into the surrounding vegetation and forests whenever threatened. Operating from these areas, they effectively employed small unit tactics to wear down the U.S. and South Vietnamese forces. While this did little to "win the war" militarily, it drove the political cost up measurably, especially in the United States.

Understandably, U.S. forces worked hard to defeat these tactics. ${ }^{22}$ One approach was to destroy forests and dense vegetation to deny the enemy cover, mobility, logistic support, and, in some cases, sustenance. U.S. forces utilized two techniques-beyond merely bombing the targeted zones with conventional munitions (an especially ineffective and inefficient method)-to accomplish this end. First, they dropped herbicides over enormous areas of

vegetation did not escape. Trees went up in flames, the rice plants lost their greenness, the grass burned on the ground.

THE AMERICAN HERITAGE HISTORY OF WORLD WAR II, supra note 17, at 616 .

20. See Geoffrey Best, The Historical Evolution of Cultural Norms Relating to War and the Environment, in CULTURAL NORMS, WAR AND ENVIRONMENT 18, 18-20 (Arthur H. Westing ed., 1988).

21. Probably the best account of the war's environmental impact is in ARTHUR H. WESTING, ECOLOGICAL CONSEQUENCES OF THE SECOND INDOCHINA WAR (1976).

22. Perhaps the best known of the attempted remedies was the failed Strategic Hamlet Program, an effort to deny the enemy sanctuary in villages throughout the South by securing the allegiance of the local villagers. Ultimately, this effort failed, in no small part due to the corruption and lack of commitment of the United States's South Vietnamese allies. An interesting description of the counterinsurgency effort in South Vietnam from the perspective of senior South Vietnamese officers can be found in CAO VAN VIEN \& DONG VAN KHUYEN, REFLECTIONS ON THE VIETNAM WAR 1-84 (U.S. Army Center of Military History Indochina Monographs, 1980). 
South Vietnam, both in wooded areas (86\%) and on crop lands (14\%). ${ }^{23}$ By one estimate, approximately one-tenth of South Vietnam was sprayed during the war. ${ }^{24}$ At the same time, U.S. troops used heavy tractors with large blades attached-Rome plows-to cut through vegetation and trees. Initially, the effort concentrated on clearing land alongside roads to minimize the risk of ambushes. However, in 1967 large tracts began to be leveled; by the end of the war, Rome plows had cleared nearly three-quarters of a million acres. Though more labor intensive than spraying, plowing was more effective in rendering an area unusable. As might be expected, both techniques caused extensive damage to the flora (the military objective) and fauna of the region. In particular, the operations led to massive soil erosion in Vietnam's hilly terrain. The effect on animal habitats was especially severe, for the vegetation that regenerated proved less capable of supporting animal life than in the past. $^{25}$

Between 1963 and 1972, the Air Force also seeded clouds in operations designed to lengthen the rainy season. ${ }^{26}$ Since the roadways were unpaved, U.S. forces hoped that extended rainfall would soften the road surfaces and cause them to collapse, thereby slowing movement along the Ho Chi Minh trail. ${ }^{27}$ Reportedly, a secondary goal was to degrade enemy surface-to-air missile radar capabilities. ${ }^{28}$ Disagreement exists over the success of these operations. ${ }^{29}$ Nevertheless, there is little doubt that increasing rainfall can

23. See WESTING, supra note 21, at 27. Three types of herbicides were used: Agents Orange and White operated to interfere with plant metabolism, while Agent Blue dehydrated plants. The agents were generally dispersed from the air by $\mathrm{C}-123$ aircraft. However, helicopters and even truck- and boat-mounted sprayers were also used. See id. at 24-27.

24. Approximately $2 \%$ of Indochina was sprayed, though most such operations were limited to South Vietnam. In the South, the bulk of the defoliation efforts were centered in Military Region III, which surrounded Saigon. Some $30 \%$ of this area was sprayed at least once. See id. at 28.

25. See Richard Carruthers, Intemational Controls on the Impact on the Environment of Wartime Operations, 10 ENVTL. \& PLAN. L.J. 38, 40 (1993). Arthur Westing points out that the spraying affected not only the autotrophic aspect of the ecosystem, but also the heterotrophic links (i.e., those beyond the first link in the food chain). In great part, this occurred because much animal activity takes place in the upper reaches of vegetation, which were most severely affected by the spraying. See WESTING, stupra note 21 , at 32. Westing describes the destruction resulting from the spraying, see id. at $28-40$, and from the plowing, see id. at 47-49. He also gives a general discussion of the overall damage. See id. at 63-82.

26. On March 20, 1974, the Department of Defense conducted a top secret briefing before a Senate Subcommittee in which the Department described the program. This briefing, since declassified, is reprinted in Environmental Modification Treaty: Hearings on the Convention on the Prohibition of Military or Any Other Hostile Use of Environmental Modification Techniques Before the Senate Comm. on Foreign Relations, 95th Cong. 101 (1978) [hereinafter TS Brief].

27. See id. at 102 .

28. Although this intent was not described in the TS Brief, it was noted by Seymour Hersch. He cited an unidentified U.S. government source as stating that a method of treating clouds with an acid chemical that would foil the operation of North Vietnamese radars had been developed. Other purposes of the rainmaking included, according to the Hersch report, providing "cover for infiltration of South Vietnamese commando and intelligence teams"; "serving as a "spoiler' for North Vietnamese attacks and raids"; "altering or tailoring the rain patterns over North Vietnam and Laos to aid United States bombing missions"; and "diverting North Vietnamese men and material from military operations to keep muddied roads and lines of communication in operation." Seymour M. Hersch, Rainmaking Is Used as a Weapon by U.S., N.Y. TIMES, July 3, 1972, at A1.

29. The Air Force asserted that rainfall increased by $30 \%$ in some locations, see TS Brief, supra note 26 , at 115 , but admitted that "[w]hile this program had an effect on the primitive road conditions in these areas, the results were certainly limited and unverifiable." Id. at 120. Arthur Westing noted that "[a]lthough the military seemed satisfied with the level of success of its weather-modification operations 
cause negative environmental consequences, including increased soil erosion, destruction of vegetation, and disease among animals.

For the first time, the environmental impact of military operations drew domestic and international attention. Multiple factors contributed to this new phenomenon. A general increase in environmental awareness coincided with the Vietnam War to help focus public attention on the environmental effects of the war. So, too, did antiwar sentiment. In a sense, the environmental damage provided a rallying point-one that did not smack of purely political motivation-for opposition to the conflict. These factors came together as war began to be brought into the living room nightly through television. For the first time in history, the general public witnessed the consequences of a war fought halfway around the globe.

Not only did the conflict spotlight the fact of environmental damage, but it also raised questions of its legality. Indeed, the State Department's legal staff recommended that the defoliation operations be limited to the territory of South Vietnam and Laos, lest they be interpreted as precedent for use by others elsewhere. ${ }^{30}$ In South Vietnam, the operations would have negligible precedential effect because the South Vietnamese consented to application of the chemicals.

Despite official sensitivity, environmental legal norms were still in a nascent stage. ${ }^{31}$ Even at this late stage, no law of war treaty mentioned the word "environment." Predictably, calls for new law were soon heard. For example, Senator Claiborne Pell proposed a draft treaty to "prohibit and prevent, at any place, any environmental or geophysical modification activity as a weapon of war. ${ }^{32} \mathrm{He}$ also recommended the prohibition of research aimed at the development of such weapons. In July 1973, his document was deemed a "sense of the Senate," 33 an important first step towards the Environmental Modification Convention (ENMOD) that came into force a mere five years later. ${ }^{34}$

Particularly interesting was a proposal, this time emanating from the halls of academia, by Princeton's Richard Falk. Adopted at the Emergency Conference Against Environmental Warfare in Indochina, held in Stockholm in June 1972 it included a Convention on Ecocide that criminalized many of the activities in which the United States had engaged during the war. ${ }^{35}$ For instance, the Convention defined ecocide as, inter alia,

in Indochina, a dispassionate arbiter would be hard put to recognize a basis for this optimism." WESTING, supra note 21 , at 56 (citation omitted).

30. See George H. Aldrich, Prospects for the United States Ratification of Additional Protocol I to the 1949 Geneva Conventions, 85 AM. J. INT'L L. 1, 14 (1991).

31. For instance, the use of Agent Orange continued to be characterized as an issue of primarily tort, rather than environmental, law. This point was noted in the U.S. Army's post-Desert Storm/Shield legal report. See LEGAL SERV. AGENCY, U.S. ARMY, THE DESERT STORM ASSESSMENT TEAM'S REPORT TO THE JUDGE ADVOCATE GENERAL OF THE ARMY pt. G, at 1 (1992) [hereinafter ARMY ASSESSMENT].

32. S. Res. 71, 93d Cong. (1973).

33. Id.

34. See Convention on the Prohibition of Military or Any Other Hostile Use of Environmental Modification Techniques, Dec. 10, 1976, 31 U.S.T. 333, 1108 U.N.T.S. 152 [hereinafter ENMOD].

35. See Proposed International Convention on the Crime of Ecocide, reprinted in Richard A. Falk, Environmental Warfare and Ecocide-Facts, Appraisal, and Proposals, 4 BULL. PEACE PROPOSALS 80 app. I at 93-95 (1973) [hereinafter Proposed International Convention on the Crime of Ecocide]. 
(b) The use of chemical herbicides to defoliate and deforest natural forests; (c) The use of bombs and artillery in such quantity, density, or size as to impair the quality of the soil or to enhance the prospect of diseases dangerous to human beings, animals, or crops; (d) The use of bulldozing . . . to destroy large tracts of forest or cropland for military purposes; (e) The use of techniques designed to increase or decrease rainfall or otherwise modify weather as a weapon of war. ${ }^{36}$

The Convention also forbade the forcible removal of human beings or animals from their habitats and the employment of weapons of mass destruction (WMD). ${ }^{37}$ Those who committed such acts, or were otherwise culpable for their commission, would, at minimum, be removed from any position of public trust. ${ }^{38}$ Professor Falk also recommended the passage of national implementing legislation, as well as the establishment of a Commission for the Investigation of Ecocide. ${ }^{39}$ In certain cases, the United Nations would be called upon to take "appropriate" action under the U.N. Charter to prevent and suppress ecocide. ${ }^{40}$ This implied that ecocide could amount to a breach of peace or act of aggression that might warrant a forceful response under article 42 of the Charter. ${ }^{41}$

The conference also adopted the Draft Protocol on Environmental Warfare. ${ }^{42}$ It began by claiming that "environmental warfare has been condemned by public opinion throughout the world." 43 Signatories therefore agreed "as a matter of conscience and of law to refrain from the use of tactics and weapons of war that inflict irreparable harm to the environment or disrupt fundamental ecological relationships." 44 In addition to outlawing weapons of mass destruction, the document specifically prohibited spreading chemical defoliants, bulldozing, and employing conventional munitions that cause extensive cratering. The Protocol deemed such violations a crime under international law, thus allowing for individual responsibility. ${ }^{45}$

Though the community of nations never formally adopted either proposal, it was clear that laws to protect the environment-the newest "victim" of war-were on the horizon. A two-track approach was taken. First, negotiations to limit the use of the environment as a weapon led to the

36. Id. art. 1 , at 93.

37. See id. art. 2 , at 93 .

38. See id. ant. 4 , at 93 .

39. See id. art. 6, at 93-94.

40. See id. art. 9 , at 94 .

41. "The Security Council shall determine the existence of any threat to the peace, breach of peace, or act of aggression and shall make recommendations, or decide what measures shall be taken in accordance with Articles 41 and 42 , to maintain or restore international peace and security." U.N. CHARTER art. 39. "The Security Council may decide what measures not involving the use of force are to be employed to give effect to its decisions . . ..."Id. art. 41. "Should the Security Council consider that measures provided for in Article 41 would be inadequate or have proven to be inadequate, it may take such action by air, sea, or land forces as may be necessary to maintain or restore international peace and security." Id. art. 42.

42. Draft Protocol on Environmental Warfare, reprinted in Falk, supra note 35, app. II at 95-96 [hereinafter Draft Protocol on Environmental Warfare].

43. Id. at 95 .

44. Id.

45. See id. For Professor Falk's views on ecocide and environmental warfare (as well as reprints of both proposed documents), see Richard A. Falk, Environmental Warfare and Ecocide, in 4 THE VIETNAM WAR AND INTERNATIONAL LAW 287 (Richard A. Falk ed., 1976); see also Falk, supra note 35. 
Convention on the Prohibition of Military or Any Other Hostile Use of Environmental Modification Techniques Convention (ENMOD). Opened for signature in 1977, this convention came into force for the United States in January 1980. By the terms of ENMOD, states agree not to "engage in military or any other hostile use of environmental modification techniques having wide-spread, long-lasting or severe effects as the means of destruction, damage or injury" to other parties ${ }^{46}$ Reminiscent of the treaty called for by Senator Pell in 1972, ENMOD was the first environment-specific law of armed conflict. However, it does not necessarily protect the environment proper. Instead, ENMOD proscribes environment-modifying processes as a method of warfare only if significant destruction, damage, or injury would result. Whether that damage is to the environment is irrelevant, though in most cases it would be.

Contemporaneously, the second track was taken. The Vietnam experience had highlighted the need to account in the law of war for the new methods, means, and characteristics of armed conflict. Existing international conventions, notably the Hague and Geneva Conventions, had been designed to apply to a genre of warfare very different from that prevalent in Vietnam. In response, the international community gathered between 1974 and 1977 under the auspices of the ICRC to bring the law of war up to date. This Diplomatic Conference on the Reaffirmation and Development of International Humanitarian Law Applicable in Armed Conflicts met on four occasions to draft Protocols Additional I and II to the Geneva Conventions. ${ }^{47}$

Protocol I, governing international armed conflict, is central to the environmental law of war, for it contains the only specific prohibitions on damaging (as opposed to using) the environment. Article 35(3) provides that "[i]t is prohibited to employ methods or means of warfare which are intended, or may be expected, to cause widespread, long-term and severe damage to the environment." ${ }^{48}$ The protocol devotes article 55 to the subject:

1. Care shall be taken in warfare to protect the natural environment against widespread, long-term and severe damage. This protection includes a prohibition of the use of methods or means of warfare which are intended or may be expected to cause such damage to the natural environment and thereby to prejudice the health or survival of the population.

2. Attacks against the natural environment by way of reprisals are prohibited. ${ }^{49}$

ENMOD and Protocol I reveal a directional trend in the environmental law of war. Prior to the Vietnam experience, attitudes towards the environment were purely anthropocentric. The lack of any mention of the environment in the law of war suggests that it was understood solely in its utilitarian context. Indeed, it would be difficult to assert that the international community viewed the environment as a distinct entity at all. However, by the end of the Vietnam War the concept of an "environment" had been grasped, albeit primarily anthropocentrically. This perspective is evident in ENMOD's prohibition on the use of (but not damage to) the environment and in the

46. ENMOD, supra note 34, art. I, para. 1.

47. Protocol I, supra note 8; Protocol II, supra note 10.

48. Protocol I, supra note 8, art. 35, para. 3.

49. Id. art. 55 . 
requirement of article 55 that the threshold environmental damage prejudice the population's health or survival. Only in article 35(3) does a prescription appear that is divorced from impact on the human population. By its formula, the question is the degree of damage to the environment, rather than its effect in human terms. As shall be discussed below, the drafters included article 35 (3) to appease intrinsic value advocates who urged protection of the environment per se. Thus, while the cognitive perspective was primarily anthropocentric in the immediate post-Vietnam period, it was an anthropocentrism increasingly sensitized to the existence of the environment qua environment. Moreover, the first glimpses of an evolutionary trend in the direction of intrinsic valuation were apparent. It should be noted that the United States, although a participant in the negotiations, has elected not to ratify Protocol I, a decision motivated in part by opposition to its environmental provisions. ${ }^{50}$

In the 1980 s, efforts to strengthen the environmental law of war faded. This was true despite significant environmental damage during the Iran-Iraq War-particularly oil spills caused by the tanker war. Between May 1980 and December 1987, some 447 tankers were attacked in the Persian Gulf. ${ }^{51}$ Also attacked were oil facilities, both ashore and offshore. These operations caused substantial damage. For example, raids against Iran's Nowruz oil drilling facility in 1983 led to the release of two million barrels of oil into the Persian Gulf. Iraq's refusal to agree to a temporary truce that would allow the wells to be capped compounded the situation..$^{52}$

Yet despite the pervasive environmental destruction, the international legal community focused far more attention on neutrality issues. Perhaps this was because the leading nations of the world were nonbelligerents during the Iran-Iraq War. By framing tanker destruction in neutrality terms, neutrals could concentrate on maintaining a free flow of oil, an emphasis that had the

50. For articles bearing on the debate over ratification, see George H. Aldrich, Progressive Development of the Laws of War: A Reply to Criticisms of the 1977 Geneva Protocol 1, 26 VA. J. INT'L L. 693 (1986); Aldrich, supra note 30; David A. Bagley, Ratification of Protocol I to the Geneva Conventions of 1949 by the United States: Discussion and Suggestions for the American Lawyer-Citizen, 11 LOY. L.A. INT'L \& COMP. L.J. 439 (1989); Hans-Peter Gasser, AGORA: The U.S. Decision Not to Ratify Protocol I to the Geneva Conventions on the Protection of War Victims, 81 AM. J. INT'L L. 910 (1987); Michael J. Matheson, Session One: The United States Position on the Relation of Customary International Law to the 1977 Protocols Additional to the 1949 Geneva Conventions, 2 AM. U. J. INT'L L. \& POL'Y 419 (1987); Guy B. Roberts, The New Rules for Waging War: The Case Against Ratification of Additional Protocol I, 26 VA. J. INT'L L. 109 (1985); William G. Schmidt, The Protection of Victims of International Armed Conflicts: Protocol I Additional to the Geneva Conventions, 24 A.F. L. REV. 189 (1984); Abraham D. Sofaer, AGORA: The U.S. Decisions Not to Ratify Protocol I to the Geneva Conventions on the Protection of War Victims, 82 AM. J. INT'L L. 784 (1988).

51. In 1984 alone, over two million tons of oil were spilled into the Gulf. See Phillipe Antoinc, International Humanitarian Law and the Protection of the Environment in Time of Armed Conflict, INT'L REv. RED CROSs, Nov.-Dec. 1992, at 517, 530. Mr. Antoine asserts that the damage caused during the tanker war rose to the level of "widespread, long-term and severe," though neither Iran nor Iraq was party to Protocol I. See id.

52. See 29 KESSING's CONTEMP. ARCHIVES 32, 594-95 (1983); see also Margaret T. OkoroduduFubara, Oil in the Persian Gulf War: Legal Appraisal of an Environmental Warfare, 23 ST. MARY's L.J. 123, 129-31 (1991); George K. Walker, Oceans Law, the Maritime Environment, and the Law of Naval Warfare, Paper Presented at the Symposium on the Protection of the Environment During Armed Conflict and Operations Other Than War, in NWC SYMPOSIUM PAPERS, supra note 13 (manuscript at 2-3, on file with The Yale Journal of International Law). 
practical effect of indirectly fostering broader environmental interests. The prevailing paradigm of the Iran-Iraq War would shift dramatically with the Iraqi invasion of Kuwait in 1990.

\section{The Gulf War}

The Gulf War brought warfare's environmental destructiveness to the forefront of international attention. Even before the air campaign commenced on January 17, 1991, there were clear indications that, environmentally speaking, this conflict would represent a new model. As early as September 1990, Saddam Hussein threatened to destroy oil fields if Coalition forces attempted to expel him from Kuwait. ${ }^{53}$ Other senior Iraqi leaders made similar pronouncements. Two days before Christmas, for example, the Iraqi Defense Minister, Said Tuma Abbas, responded to Secretary of Defense Cheney's statement that the "clock is ticking" by boasting that "Cheney will see how land burns under the feet of his troops and stooges." 54 That very month the Iraqis detonated six Kuwaiti oil wells to practice for later operations. ${ }^{55}$

Those beyond Iraqi borders viewed these bellicose statements as more than mere puffery. Among the most vocal in singling out the environmental threat was King Hussein of Jordan. Speaking in November at the Second World Climate Conference in Geneva, he pointed to the possibility of widespread environmental destruction in an attempt to prevent war. ${ }^{56}$ The Secretary General of Jordan's Higher Council for Science and Technology, Dr. Abdullah Toukan, echoed the theme at a scientific symposium held in London in January. He warned that the destruction of the Gulf's oil installations could lead to the spillage of up to two million barrels of oil per day. At the same meeting, John Cox, a chemical engineer experienced in the field, suggested that igniting the oil installations could generate smoke equal to that produced by a nuclear explosion, thereby blotting out sunlight and

53. On September 23, 1990, the Iraqis released a statement following the joint meeting of the Iraqi Revolution Command Council and the regional command of the Arab Socialist Baath Party, chaired by Saddam Hussein. It proclaimed:

The oil, its areas, and Israel will be transformed into something different from what they are now. Thus" will be the deluge. . . . The oil areas in Saudi Arabia and in other parts of the states of the region and all the oil installations will be rendered incapable of responding to the needs of those who came to us as occupiers in order to usurp our sovereignty, dignity and wealth.

Partial Text of Statement by Iraq's Revolution Command Council, REUTERS, Sept. 23, 1990, available in LEXIS, News Library, Allnws File; see also Nora Boustany, Saddam Threatens Mideast's Oil Fields: "Choking" Embargo Cited as Justification, WASH. PosT, Sept. 24, 1990, at A1.

54. Gayle Young, Cheney: "Clock is Ticking" for War, UPI, Dec. 23, 1990, available in LEXIS, News Library, Allnws File.

55. William M. Arkin, The Environmental Threat of Military Operations, Paper Presented at the Symposium on the Protection of the Environment During Armed Conflict and Operations Other Than War, in NWC SYMPOSIUM PAPERS, supra note 13 (manuscript at 6, on file with The Yale Journal of International Law).

56. King Hussein warned of an "environmental catastrophe." Gulf War Threatens Environment, Jordan King Warns, L.A. TIMES, Nov. 6, 1990, at A2. 
causing a drop in temperatures by as much as sixty-eight degrees. ${ }^{57}$

Oxford's Adam Roberts has noted astutely that the environmental issue soon took on political overtones. Those concerned with the environmental impact of hostilities generally opposed the war, whereas supporters of Iraqi expulsion by force of arms devoted little attention to environmental matters. For Professor Roberts, this "polarization" had an important consequence: "There was little if any public discussion of the means which might be used, if there was a war, to dissuade Iraq from engaging in environmentally destructive acts; and little if any reference to the laws of war as one possible basis for seeking limitations of this kind." 58 As one possible remedy, he suggested an unequivocal pre-Desert Storm pronouncement by the United Nations that the laws of war were applicable to environmental damage. ${ }^{59}$

At that late date, it is doubtful that putting Iraqi leaders on notice would have yielded significant deterrent returns. After all, the Iraqis already had violated international law with impunity on multiple occasions. For example, the seizure of foreign civilians and the use of them as human shields were breaches beyond even theoretical doubt. Their subsequent release can be attributed more to "rational" decisionmaking than to any last-minute epiphany that the acts were unlawful. The same can be said with regard to chemical weapons. Was it law or the thinly veiled threat of retaliation with weapons of mass destruction that deterred Saddam Hussein?

To complicate matters, the law in this area was (and still is) unsettled-a point Iraq probably grasped better than most, given its experiences during the war with Iran. An eleventh-hour proclamation on the environmental law of war by the United Nations, which had proven impotent during the Cold War and was now being informally led by a Protocol I nonsignatory, would hardly have proven a panacea. Furthermore, the last international war crimes trials had been held over forty years earlier in the aftermath of the Second World War. Therefore, not only was the law uncertain (a point discussed more fully below), but there was also evidence of the international community's unwillingness to impose state or individual responsibility following armed conflict. That said, Professor Roberts's suggestion is well taken. Emphasizing the law of war would have hurt nothing, was the right thing to do,

57. Scientists Warn of Environmental Disaster from a Gulf War, REUTERS, Jan. 2, 1991, available in LEXIS, News Library, Allnws File; see also Experts Warn of Global Fallout from Warfare: Environment; Scientists Say that Smoke from Blazing Kuwait Oil Fields Could Affect the Climate, L.A. TIMES, Jan. 3, 1991, at A8.

58. Roberts, supra note 18 , at 31 .

59. In his words, "[n]ew environmental threats and public environmental concerns strengthened the case for having a clear statement about how environmental destruction ran counter to older as well as newer agreements on the laws of war." Id. at 33. Along these lines, Professor Roberts made a very good point:

The failure to prevent damage to the environment in the 1991 Gulf War was in marked contrast to a degree of success in preventing the conflict from getting out of hand in some other respects: many hostages, seized in the early weeks of the Iraqi occupation of Kuwait, were released before war broke out; Iraq was kept isolated; the war was kept within geographical limits and was brought to a swift conclusion; and gas, bacteriological and nuclear weapons were not used. Why was there so conspicuous a failure over matters relating to the Id. at 4 . environment? 
and-considering the minimal military value of his actions-might have given Saddam Hussein pause. It certainly would have strengthened the basis for condemnation by the international community after the hostilities.

Just prior to the commencement of the air campaign, President Bush did specifically address destruction of oil fields and installations. In the nowfamous letter from President Bush to Saddam Hussein, which Iraqi Foreign Minister Tariq Aziz refused to accept from Secretary of State James Baker in Geneva on January 9, the President warned that "[y]ou and your country will pay a terrible price if you order unconscionable acts of this sort." The ICRC also endeavored to focus attention on the potential belligerents' international legal obligations. It issued its most comprehensive reminder in the form of a note verbale (with attached memorandum of law) on December $14,{ }^{61}$ not long after the Security Council passed Resolution $678 .{ }^{62}$ The resolution authorized the use of "all necessary means" to implement Resolution 660 (the demand for Iraqi withdrawal) ${ }^{63}$ and to restore peace and security. ${ }^{64}$ Each of the 164 parties to the 1949 Geneva Conventions received the note verbale.

In it, the ICRC reiterated numerous customary and conventional laws of armed conflict. The memorandum of law specifically cited article 55 of Protocol I, and invited states that were not parties to the Protocol (for example, Iraq, France, the United Kingdom, and the United States) to respect that article. It also urged compliance with article 56, a provision that extends protection to works and installations containing dangerous forces, such as dams and nuclear generating stations. ${ }^{65}$ This protection, as shall be seen, has important environmental implications. When the air campaign was launched in January, the ICRC issued yet another appeal to respect the law of war. ${ }^{66}$ On February 1, with oil now pouring into the Persian Gulf, the ICRC issued its strongest pronouncement. Warning that the law of war "might be swept aside by the political, military or propaganda demands of the moment," it emphasized that "[t]he right to choose methods or means of warfare is not unlimited. Weapons having indiscriminate effects and those likely to cause disproportionate suffering and damage to the environment are prohibited." 67

The ICRC's warnings and pleas had little effect. Two days after the air

60. Text of Bush Letter to Saddam Hussein, UPI, Jan. 12, 1991, available in LEXIS, News Library, UPI File. Additionally, destruction of the Kuwaiti oil resources was one of the three "unconscionable acts" for which the Iraqi leadership would be held personally responsible-the others being use of chemical/biological weapons and terrorism. See Arkin, supra note 55, at 2-3 (citing National Security Directive (NSD) 54, Jan. 15, 1991). NSD 54 remains classified, but is described generally in CHRISTOPHER SIMPSON, NATIONAL SECURTY DIRECTIVES OF THE REAGAN AND BUSH ADMINISTRATIONS 947 (1995). NSD 54 authorized offensive operations against Iraqi forces. Id.

61. ICRC, Note Verbale and Memorandum (Dec. 14, 1990), reprinted in INT'L REV. RED CROSS, Jan.-Feb. 1991 [hereinafter ICRC Note Verbale].

62. S.C. Res. 678, U.N. SCOR, 45th Sess., 2963d mtg., U.N. Doc. S/RES/678 (1990). On this resolution, see Burns H. Weston, Security Council Resolution 678 and Persian Gulf Decision Making: Precarious Legitimacy, 85 AM. J. INT'L L. 516 (1991).

63. S.C. Res. 660, U.N. SCOR, 45th Sess., 2932d mtg., U.N. Doc. S/RES/660 (1990).

64. See S.C. Res. 678, supra note 62, para. 2 .

65. See ICRC Note Verbale, supra note 61, at 22-26.

66. ICRC, Appeal (Jan. 17, 1991), reprinted in INT'L REV. RED CROss, Jan.-Feb. 1991, at 26.

67. ICRC, Appeal (Feb. 1, 1991), reprinted in INT'L REV. RED CROSS, Jan.-Feb. 1991, at 27. 
war commenced, the Iraqis began pumping oil into the Persian Gulf from Sea Island Terminal, an offshore oil loading dock. The flow was stemmed only after Coalition air forces bombed the terminal. ${ }^{68}$ Not to be deterred, the Iraqis exacerbated the pollution by dumping oil into the Gulf from five tankers moored at Mina al-Ahmadi. The Defense Department estimates that by the end of the conflict, the Iraqis had intentionally spilled between seven and nine million barrels of oil. ${ }^{69}$ It eventually covered approximately 600 square miles of water and spread along 300 miles of shoreline. ${ }^{70}$ To place the Iraqi actions in context, the spill was the largest, intentional or accidental, in history.

Not all of the oil that found its way into the Persian Gulf derived from Iraqi actions. In fact, the first oil spill of the war may have come on the morning of the seventeenth when U.S. Navy aircraft bombed an Iraqi oil platform at Mina al-Bakr. A week later, Navy planes hit the Amuriyah, an Iraqi tanker that was refueling an air-cushioned landing craft. French aircraft struck a tanker of their own that same day. Other air attacks may also have contributed to the spills. $^{71}$ These operations are, however, easily distinguishable from the Iraqi actions. Not only were Coalition-caused releases dwarfed by those of the Iraqis, but there is no evidence to suggest purposeful environmental damage by Coalition forces. From a legal perspective, these are critical facts, for there is a clear difference in the law between incidental (collateral, in law of war terminology) and intentional damage.

Soon after Desert Storm began, the Iraqis started destroying oil wells to complement their maritime misconduct. For instance, on January 21, they detonated sixty wells in the vicinity of Al Wafra in Kuwait. They also set fire to the Mina ash Shuaybah and Mina Abd Allah oil installations on the coast. $^{72}$ Nevertheless, it was not until just prior to the start of the ground war on February 23-24 that systematic destruction began in earnest, with the Al Burgan oil fields suffering the heaviest toll. By the end of hostilities, the Iraqis had damaged or destroyed 590 oil well heads. Of these, 508 were set afire, and eighty-two were damaged in a manner that caused oil to flow from

68. See Peter Ford, Vital Saudi Water Plant Prepares for Oil Slick, CHRISTIAN SCI. MONITOR, Feb. 1,1991 , at 1 .

69. See U.S. DeP'T OF DEFEnSE, CONDUCt of the PERSIAN GulF WaR: Final Report to CONGRESS, at O-26 (1992) [hereinafter DOD REPORT]. A Greenpeace study cites similar figures, but notes that smaller quantities of oil continued to leak into the Gulf until May or early June of 1991. See WILLIAM M. ARKIN ET AL., ON IMPACT: MODERN WARFARE AND THE ENVIRONMENT: A CASE STUDY OF THE GULF WAR 63-64 (1991) [hereinafter GREENPEACE STUDY]. The size of the spill also is discussed in KUWAIT ENV'T PROTECTION COUNCIL, STATE OF THE ENVIRONMENT REPORT: A CASE STUDY OF IRAQI REGIME CRIMES AGAINST THE ENVIRONMENT 29-33 (1991).

70. See Walter G. Sharp, Sr., The Effective Deterrence of Environmental Damage During Armed Conflict: A Case Analysis of the Persian Gulf Wär, 137 MIL. L. REV. 1, 41 (1992).

71. See Arkin, supra note 55, at 7-8. Mr. Arkin has noted: "What the public heard during the war was that around 19 January, Iraq opened valves at the Sea Island terminal, pumping oil directly into the Gulf." Id. at 8. In fact, the Coalition contribution to the spill was reported. For instance, on February 21 , 1991, the Associated Press reported that Coalition bombing missions may have been responsible for $30 \%$ of the oil spilled. See Martin Marris, Sophisticated Radar to Gauge Size of Oil Spill, AP, Feb. 21, 1991, at 2.

72. See Arkin, supra note 55 , at 6-7. 
them. ${ }^{73}$ The blazes reached their destructive peak during May and June, when 4.5 million barrels of oil per day were lost to the fires. Several comparisons illustrate the gravity of this situation. The oil fires generated eighty-six billion watts of heat, roughly equal to that of 500 forest fires. Daily soot release into the atmosphere, which drifted as far away as the Himalayas, was the equivalent of $10 \%$ of global biomass burning, while sulfur dioxide output approximated $57 \%$ of the emissions from electrical utilities. Carbon dioxide production was at the level of $2 \%$ of the fossil fuel and biomass burning that occurs worldwide on a daily basis. ${ }^{74}$

The international community mounted an aggressive campaign to contain the spills and put out the fires. Many U.S. government agencies, with the U.S. Coast Guard at the forefront, took part in the valiant recovery operation. Foreign and international organizations that were active in the effort included the Saudi Meteorology and Environmental Protection Administration and the International Maritime Organization. Ultimately, two million barrels of oil were recovered from the Gulf. ${ }^{75}$ The battle against the burning oil wells also went well. Nearly thirty firefighting teams from ten countries attacked the blazes, extinguishing them much more quickly than had been expected. ${ }^{76}$

Despite predictions of doom such as those offered at the scientific symposium in London, the environmental damage was not catastrophic. Warnings of drastic drops in temperature, and the effect this might have on wind currents, proved very much overblown. Similarly, early fears of severe human health problems and wholesale destruction of animal habitats were not borne out. ${ }^{77}$ Nevertheless, the pooling oil, oil mist, and settling soot did damage the terrestrial environment, particularly the fragile desert ecosystem. In many areas. the annual seed flora failed to set, and perennial vegetation, critically important because its roots are a food source for many animals, incurred damage or died. Additionally, oil harmed intertidal habitats such as mangroves, beaches, and mud flats. Though no major threat to individual human health surfaced, the increase in inhalable particulants that the fires caused was significant when considered in terms of exposure of a large population. This exposure could potentially increase the prevalence and severity of disease, both chronic and acute. ${ }^{78}$ Of course, the overall

73. See DOD REPORT, supra note 69 , at $0-26$. Estimates of the number of wells damaged or destroyed by the Iraqis differ. Walter Sharp reports the figure as 732 , with 650 catching fire. See Sharp, supra note 70, at 40-41. The Kuwaiti government reported that, after February 28, 1991, 613 wells were set on fire, 76 were gushing, and 99 were damaged. See KUWAIT ENV'T PROTECTION COUNCIL, supra note 69 , at $1 \&$ fig. 2 .

74. See Sylvia A. Earle, Persian Gulf Pollution: Assessing the Damage One Year Later, NAT'L GeOGRAPHIC, Feb. 1992, at 122.

75. See Adam Roberts, Environmental Destruction in the 1991 Gulf War, INT'L REV. RED CROSS, Nov.-Dec. 1992 , at $538,549$.

76. See JOHN NORTON MOORE, CRISIS IN THE Gulf: ENFORCING THE RULE OF LAW 80 (1992).

77. The United Nations Environment Programme (UNEP) reported in May 1992 that the oil well fires did not affect the global climate and that the pollution they caused was not severe enough to result in major human health problems. See State of the Environment: Updated Scientific Report on the Environmental Effects of the Conflict Between Iraq and Kuwait, Governing Council of the U.N. Environment Programme, 17th Sess., at 12-13, U.N. Doc. UNEP/GC.17/Inf.9 (1993).

78. On the impact of the spills generally, see Report on the UN Inter-Agency Plan of Action for the ROPME Region, U.N. Environment Programme, Oct. 12, 1991 [hereinafter UNEP REPORT], reprinted 
assessment may change as unexplained health problems begin to develop among those who were present during the conflict.

Why the Iraqis committed the misdeeds remains unanswered. As will be discussed later, the degree of military advantage obtained from an act during war is a critical data point in assessing its lawfulness. The Department of Defense (DOD) has concluded that the Iraqi actions were of little military utility. In arriving at this conclusion, Pentagon analysts explored possible military benefits of the oil spills. One was to foil Coalition amphibious operations. A secondary purpose may have been to foul desalinization plants in Saudi Arabia either to disrupt military activities ashore or to cause unrest among the Saudi population by depriving it of fresh water. ${ }^{79}$ The fires arguably could have been intended to obscure Iraqi forces, shielding them from air and ground attack. ${ }^{80}$

The DOD concluded, however, that Iraq's actions were probably purely punitive in nature-"environmental terrorism," to use President Bush's characterization. ${ }^{81}$ Addressing the issue in its official Gulf War Report, the DOD points out that the oil spills had negligible effect on Coalition naval operations. If the goal was to frustrate a Coalition landing force, then the operation was very poorly conceived. The oil well fires present even more compelling circumstantial evidence of malevolent intent. If the purpose was to create obscurants, why did the Iraqis not just open the valves of the wells, allow the oil to pool, and then set it on fire? Instead, the Iraqis destroyed the wells in a manner that made it difficult to extinguish the resulting fires; this suggests a broader, longer-term purpose than merely to complicate immediate Coalition intelligence gathering, maneuvers, and attacks. ${ }^{82}$

A counterargument is that since the wells were previously wired with explosives, blowing them up may have been the most expedient method of destruction in the face of the Coalition onslaught. Interestingly, the DOD Report queries why the Iraqis did not set ablaze their own Ar-Rumaylah oil fields, which lay just across the border, if the goal was to obscure their troops from Coalition attack. This, the report contends, further demonstrates Iraq's punitive motivation. ${ }^{83}$ From the perspective of rational decisionmaking, the DOD Report falters here. Not knowing the course that the war and post-war settlement would take, it would have made very little sense for Iraq to destroy its own primary resource merely for short-term tactical and operational gain.

in IRAQ AND KuWATt: THE Hostilities AND THEIR AFTERMATH 339 (M. Weller ed., 1991).

79. See DOD REPORT, supra note 69 , at O-27.

80. See id.

81. Address Before a Joint Session of the Congress on the State of the Union, 1 PuB. PaPers 74, 79 (1991). Some have suggested that a possible motive was "ecological terrorism in retaliation for the bombing." See, e.g., Robert McFadden, Oil Threatens Fishing and Water Supply, N.Y. TimEs, Jan. 26, 1991, at 4. A more remote possibility is that the motive was economic: Iraq hoped to devastate a competitor, drive up the price of oil, or create an incentive for the removal of sanctions on its own oil exports.

82. See DOD REPORT, supra note 69 , at 0-27.

83. See id. Iraq also damaged all twenty-six gathering centers used to separate oil, gas, and water. This process is integral to oil production. Additionally, the Iraqis destroyed the wells' technical specifications. See Sharp, supra note 70, at 45 . If the purpose was military, what would have justified such acts? One possibility is that the Iraqis wanted to prevent the use of the oil wells by the Coalition forces and Kuwait. However, the DOD Report has the better argument. 
Doing so would have been very different from destroying resources in an occupied territory from which it was about to be ejected. The respective costbenefit calculations hardly yield comparable results.

Greenpeace has cited various sources to suggest that the Iraqi actions may have had military ends. For example, a Navy spokesman on the U.S.S. Midway reportedly admitted that the smoke from oil fires precluded target acquisition in some cases. ${ }^{84}$ An F-15 pilot interviewed by the Associated Press reported the same effect. ${ }^{85}$ On one occasion the Iraqis supposedly even used the smoke from a burning oil field to mask an attack. ${ }^{86} \mathrm{It}$ is not difficult to imagine the problems that Iraq might have hoped the fires would create for the Coalition. It could even be argued that the fires were intended to take advantage of "weaknesses" in high-tech Coalition weapons. Blocking ambient light, for example, diminishes the effectiveness of night vision goggles. Brightness also blinds them. ${ }^{87}$ Smoke has the former effect, fire the latter. Similarly, smoke can foil guided munitions. Consider the difficulty, for instance, of using an electro-optical guided weapon on a smoke-covered target.

Ultimately, there is little question that on various occasions Iraqi actions did affect Coalition military operations. There is also little question that they had minimal impact on the overall campaign. Given the difficulty of determining the intent of a dictator who remains in control of a closed society, probably the most objective interpretation of the oil spills and fires is that they may have been intended to achieve military advantages. Despite this possibility, the damage inflicted so outweighed possible gains that the acts were wrongful under international law. ${ }^{88}$

As a final note, it is important to remember that although the oil spills and fires stole the headlines, the war caused a great deal of additional environmental damage. Mines presented a particular problem. On many occasions, the Iraqis indiscriminately laid mine fields without adequately marking them or accurately recording their locations. This made large areas of land impassable and posed a significant danger to humans and animals alike. Massive mine-clearing efforts had to be mounted to make the land usable again. In areas controlled by Coalition forces after the war, such as the U.N. security zone in the north and Kuwait in the south, mine operations became an integral part of the international relief efforts. To a lesser extent, the same is true of unexploded ordnance (UXO), i.e., the remnants of munitions that failed to explode. ${ }^{89}$

The war also had less sensational, though still significant, effects on the environment. For instance, explosions and vehicle movement disrupted the

84. See GREENPEACE STUDY, supra note 69 , at 141 .

85. See id.

86. See id.

87. See Joel P. Kane, Night Vision Goggles and Desert Storm, MARINE CORPS GAZETTE, Feb. 1992, at 42 .

88. For discussion of the customary international law concepts of military necessity and proportionality, see infra Section III.B.

89. See Tony Horowitz, These Men Dance Through Minefields, Cleaning Up Kuwait, WALl ST. J. EUR., Jan. 21, 1992, at 1. The report noted that in the year following the war, more than 1250 civilians were killed or wounded by explosive ordnance and 5 demolition specialists had died. See id. 
desert ecosystem by loosening its surface, rendering it susceptible to wind and water erosion. Enormous quantities of hazardous materials were also generated, ranging from dishwater and human waste to antifreeze and engine oil. Despite minor problems, U.S. military forces successfully handled these substances in an environmentally responsible manner. ${ }^{90}$ In retrospect, the military campaign fielded by the United States was the most environmentally conscious in its history. Moreover, it has improved its performance since then. ${ }^{91}$ Unfortunately, not all of the world's military forces are fully sensitized to the environmental consequences of their operations. Many U.S. allies, in addition to the Iraqis, caused significant environmental damage merely by their presence.

\section{The Post-Gulf War Period}

Serious attention to the Gulf War's environmental impact was apparent as early as March 1991, when Japan proposed that the Governing Council of the United Nations Environment Programme (UNEP) adopt a declaration of principles proscribing the environmentally destructive techniques witnessed during the war. Simultaneously, France recommended a prohibition against targeting ecological areas and "world heritage monuments." ${ }^{2}$ Both proposals were raised two months later during UNEP's sixteenth Session, at which Canada and Greenpeace announced their sponsorship of conferences on the environmental law of war. Additionally, UNEP's Governing Council endorsed a prohibition against weapons that could "cause particularly serious effects on the environment." $" 93$

In June 1991, Greenpeace, in conjunction with the London School of Economics and the British Center for Defence Studies, convened its

90. For instance, in one case, a unit collected hazardous waste in barrels so as not to dump it improperly, but failed to mark the barrels. As a result, the contents had to be tested prior to disposal, an extremely costly and time-consuming process. See ARMY ASSESSMENT, supra note 31, pt. G, para. 1, at 2.

91. The Army Assessment noted that

[i]n general, there was an environmental awareness in the U.S. Army that caused us to consider the environmental consequences of military actions and kept us in concert with the law. ... This environmental awareness was carefully balanced against the often conflicting needs of waging war. In SWA [Southwest Asia], this translated to: Army policy is to adhere to United States environmental requirements if possible. As a result, environmental law issues were a SJA [Staff Judge Advocate] concern in theater as well as in the United States.

Id. pt. G, at 1-2. There were problems, however, with environmental issues during deployment. The Army Assessment noted that "[c]ommanders [wanted] to do the right thing, but [had] a low tolerance for the impractical." Id. pt. G, para. 3, at 3. Quoting an attorney from the Army's Operations and Law Division, the Assessment provides a clear indication of the mindset:

Our attitude at the time was that, you know, we've got a deployment going on. To the extent that we can respect the environment, that's fine, but it's not our job .... We've got other things to do and essentially, I don't know if you call it what we did, "stonewalling," but essentially, the environmental issues, as far as we saw, went away for the long term.

Id. The Assessment characterized this statement not as "callousness to environmental concerns," but instead as "the frustration of trying to deal with environmental laws drafted without regard for military necessity." Id.

92. See James P. Terry, The Environment and the Laws of War: The Impact of Desert Storm, 15 NAVAL WAR C. REV. 61, 65 (1992).

93. G.A. Res. 16/11, U.N. GAOR, 16th Sess., Supp. No. 25, at 48, U.N. Doc. A/46/25 (1992). 
conference in London. For the conference, Professor Glen Plant of the London School of Economics developed a straw man outline of what the elements of a Fifth Geneva Convention on the Environment might look like. ${ }^{94}$ Its most significant provision dealt with methods and means of warfare, setting forth four options for a threshold at which environmentally destructive methods and means should be prohibited:

Option (a): prohibiting the employment of methods or means of warfare which are intended, or may be expected, to cause any (except de minimis) damage to the environment; Option (b): prohibiting it at least where the damage is widespread, long-lasting or severe;

Option (c): prohibiting it as under alternative (b), but adding a fourth alternative criterion, "significant" (or "appreciable") and irreversible;

Option (d): choosing some midway position between alternative (b) and the existing excessively high threshold as it appears in Article 35(3) of Protocol I. ${ }^{95}$

Despite generating a great deal of attention and Greenpeace support, ${ }^{96}$ Professor Plant's proposal has not led to a serious international effort to produce an agreement along the lines suggested. ${ }^{97}$

In July 1991, the Canadian Ministry of External Affairs convened its own conference. The prevailing view of those who gathered in Ottawa was that the existing law adequately addressed the environmental effects of war. However, they recognized the need to consider the evolutionary nature of environmental concerns when applying existing prescriptions. In other words, the "value" of the environment would shift over time, an important factor in performing the balancing tests that dominate the law of war. The conference also took the position that peacetime norms generally remain applicable during hostilities. $^{98}$

Of particular interest was the position of the U.S. participants. According to one account of the proceedings, they

carefully underscored the merits of the existing regime, which is based on the principles of military necessity and proportionality under the law of armed conflict. The U.S. concern regarding more restrictive environmental provisions is that they could be implemented only at the expense of otherwise lawful military operations-such as attacking targets which require fuel-air explosives (FAE) for their destruction. ${ }^{99}$

This is a revealing statement because almost all treaty law of war, except that which merely codifies customary law, limits otherwise legal activities. That is its purpose: to render illegal those legal activities that become contrary to current normative values. The U.S. participants clearly were taking the stance

94. Glen Plant, Elements of a 'Fifth Geneva' Convention on the Protection of the Environment in Time of Armed Conflict, in ENVIRONMENTAL PROTECTION AND THE LAW OF WAR 37, 43-61 (Glen Plant ed., 1992).

95. Id. at 46 .

96. See The Gulf War: Environment as a Weapon, 85 AM. SOC'Y INT'L L. PROC. 214, 220 (1991) (remarks of Sebia Hawkins).

97. The proceedings of the conference are published in ENVIRONMENTAL PROTECTION AND THE LAW OF WAR, supra note 94 , at $65-150$.

98. See Hans-Peter Gasser, For Better Protection of the Natural Environment in Armed Conflict: A Proposal for Action, 89 AM. J. INT'L L. 637, 639 (1995); see also infra Subsection III.A.1.

99. Terry, supra note 92 , at 65 . 
that the present law suffices, that is, it reflects the global community's values and serves its aspirations.

Arguments of this nature represent a failure to see the forest for the trees. That a regime might restrict useful means does not necessarily lead to the conclusion that it deserves rejection. Instead, the question is whether the new regime represents an overall step forward (however one defines "forward"). Furthermore, to argue for rejection of a legal regime because it would limit currently legal techniques is, in a sense, meaningless. The relevant factor is not the weapon used, but its target. Simply put, what are the consequences if a target cannot be struck, or be struck as effectively, as otherwise would be the case?

Opposition to additional prescriptions on the grounds that they might limit the ability to employ otherwise lawful techniques is classically anthropocentric. By the Ottawa Conference, the lines of demarcation between two opposing camps were becoming clear. One side, exemplified by Greenpeace, had adopted an intrinsic worth approach and took the stance that more law was needed. The anthropocentrics, on the other hand, hesitated to extend the law further out of concern that the hands of the decisionmakers might be tied. In their view, the law should be left alone to evolve within the existing framework.

In December 1991, a third major international conference convened in Munich. Co-sponsored by the International Council of Environmental Law (ICEL) and the Commission on Environmental Law of the International Union for the Conservation of Nature and Natural Resources, and financed in part by the Dutch government, it brought together a distinguished group of scholars and practitioners. The conference broke into two working groups: the first to consider how the effectiveness and implementation of existing legal instruments might be improved, the second to reflect on possible directions for further development of the legal regime governing the environmental law of war. ${ }^{100}$ They produced a series of innovative recommendations that are particularly useful in focusing attention on alternatives to the current state of affairs.

As to the present law, the conference recommended that Protocol $\mathrm{I}$, and other relevant legal instruments, be universally accepted. It stressed the importance of customary international law norms (e.g., military necessity) to environmental protection, as well as the need to disseminate effectively the law of armed conflict. In an interesting comment, the final report also "observed that the current recognition that the environment itself is an object of legal protection in times of armed conflict implies that traditional perceptions of proportionality and military necessity have become obsolete."101 This assertion is a bit inartfully stated, for it would have been more accurate to note that the traditional perceptions are evolving. Nevertheless, the statement demonstrates movement along the continuum

100. See International Council of Envtl. Law, Law Concerning the Protection of the Environment in Times of Armed Conflict, Final Report of Consultation of Dec. 13-15, 1991, at 1 (unpublished memorandum, on file with author) [hereinafter Munich Report].

101. Id. para. 2 . 
between the anthropocentric and intrinsic value cognitive perspectives because it is based on the proposition that the environment per se should be protected. However, the recommendation does not go so far as to suggest that the environment should be safeguarded absolutely without regard to human-related considerations.

With respect to the further development of the law, a number of innovative recommendations were proffered. The conference report proposed that any new law be based on protection of the environment per se. ${ }^{102}$ Again, while this is not necessarily an intrinsic value perspective, it does lean in that direction. Although it did not recommend a new convention, the report did suggest the compilation of two lists. The first would consist of activities during hostilities that could harm the environment, some of which would be absolutely forbidden, with others allowed only conditionally. Reflecting the desire to protect the environment per se, the law would prohibit: "(i) intentional attacks on the environment; (ii) the manipulation of natural processes causing environmental damage; and (iii) significant collateral damage to the environment." 103 Violations would constitute grave breaches under international law, thereby imbuing all states with the jurisdictional competence to seize and try alleged offenders.

The second list would consist of a registry of protected areas. Though criteria for inclusion would have to be developed, inventories such as the U.N. List of National Parks and Equivalent Reserves, the Ramsar Wetlands of International Importance, the UNESCO Biosphere Reserves, and the Council of Europe's Biogenic Reserves could be adopted immediately. As to areas not on one of these preexisting lists, studies would have to be conducted to determine their vulnerability to military activities. Ultimately, areas selected for protection would be noted on maps and marked. with distinctive symbols. ${ }^{104}$

The report also urged states to rethink and revise targeting practices in light of technological advances. As an example, it pointed to the sinking of oil tankers. Noting the myriad of methods for preventing the delivery of oil to an adversary, the group argued that actual destruction of vessels should be avoided. Specifically proscribed as targets were sites that contained dangerous forces or in which ultrahazardous activities were carried out. ${ }^{105}$ This restriction harkens back to article 56 of Protocol I, which limits how and when works containing "dangerous forces" can be attacked. ${ }^{106}$ However, whereas article 56's interpretation usually is limited to dams, dikes, and nuclear electrical generating stations, ${ }^{107}$ the Munich proposal would extend protection beyond these categories. For instance, oil reserves were cited as protected targets, an illustration clearly selected with the Gulf War experience in mind. The group also addressed practices from that war when it recommended prohibiting the targeting of "potentially dangerous" sites, i.e.,

102. See id. para. 10 .

103. Id. para. 13(a).

104. See id. para. 13(b).

105. See id. para. 16.

106. Protocol I, supra note 8, art. 56, para. 1.

107. See infra Subsection III.C.3. 
those essential either to human health or to the environment. Examples are water purification facilities and sewage treatment plants. ${ }^{108}$

To enforce the prohibitions, the conference recommended the imposition of state responsibility for either actual or potential damage. Potential damage would be measured by the likelihood of occurrence and the magnitude of harm. ${ }^{109}$ Characterizing potential damage as actionable represents a novel approach to the issue of state responsibility, because under international law states are seldom responsible for speculative future damage. As the report noted, the concept of responsibility would have to be refined by states, as well as by various national and international governmental and nongovernmental organizations, "in order to make it fully operational."110 Certainly, refinement would include clarifying what is meant by potential damage; it would also require crafting remedies. The group recommended a scheme whereby damaged or destroyed aspects of the environment would be replaced or restored to a pre-war level. When restoration was not possible, "compensation in kind would be required." 111

Finally, the Munich Conference took on the jus ad bellum issue of when environmental damage amounts to a threat to, or breach of, peace-a characterization that permits response under the U.N. Charter. ${ }^{112}$ In particular, it included threatened or actual damage to "the commons" in the category of threat/breach. ${ }^{113}$ The term extends to areas such as the high seas, which are res communes. Beyond singling out the matter as an issue of importance, and blandly stating the obvious proposition that in the event of a threat or breach "appropriate measures" should be taken, the conference accomplished little else regarding the jus ad bellum. Nevertheless, the Munich Conference was significant in that it generated a consensus product consisting of substantive recommendations. Though the international community is not likely to adopt these without modification any time soon, the conference's recommendations provide a useful point of departure in discussions of how new law might be shaped.

A fourth conference of significance, although dedicated to environmental law issues extending well beyond armed conflict, was the June 1992 United Nations Conference on the Environment and Development (UNCED) in Rio de Janeiro. It issued the Rio Declaration, principle 24 of which specifically addressed environmental concerns in warfare: "Warfare is inherently destructive of sustainable development. States shall therefore respect international law providing protection for the environment in times of armed conflict and cooperate in its further development, as necessary." 114 The compromise character of the declaration is apparent. It responds to claims of the law's adequacy when it urges respect, but displays a revisionist flavor by

108. See Munich Report, supra note 100 , para. 16.

109. See id.

110. Id.

111. Id. para. 18.

112. See U.N. CHARTER art. 39.

113. See Munich Report, supra note 100 , para. 17.

114. Rio Declaration on Environment and Development, princ. 24, U.N. Doc. A/CONF.151/Rev. 1 (1992) [hereinafter Rio Declaration], reprinted in 31 I.L.M. 874. 
encouraging cooperation in the law's continued development.

As the various conferences were being held, the United Nations proper was addressing the matter. The effort began in earnest in July 1991 when the Jordanian representative forwarded a note verbale to the Secretary General faulting the ENMOD Convention for its ineffectiveness in preventing Gulf War environmental damage. Claiming that the Convention was so vague and broad as to be unenforceable, Jordan also criticized the lack of any dispute resolution mechanism in the ENMOD regime. ${ }^{115}$ To remedy these shortcomings, Jordan urged the creation of a committee to examine the environmental law of war and make recommendations for its improvement. In doing so, Jordan held out the drafting of a new treaty as one remedial option. ${ }^{116}$

The General Assembly referred the matter to the Sixth (Legal) Committee, which placed the item on its 1991 agenda under the title "Exploitation of the Environment as a Weapon in Time of War." Jordan, emphasizing that the issue was broader than use of the environment as a weapon, argued for expanding consideration to encompass environmental damage generally. ${ }^{117}$ The title was changed accordingly to "Protection of the Environment in Times of Armed Conflict." 118

During the multiple meetings of the Sixth Committee, there was general consensus that Iraq's intentional dumping of oil into the Persian Gulf and setting ablaze of oil wells constituted violations of international law. ${ }^{119}$ As evidence, several states referred to Security Council Resolution 687, which held Iraq liable for "any direct loss, damage, including environmental damage, and the depletion of natural resources" caused by the Iraqi invasion. ${ }^{120}$ In fact, Resolution 687 liability derived not from the environmental law of war, but instead from the $a b$ initio unlawfulness of the Iraqi use of force. Resolution 687 reflected the jus ad bellum, not the jus in bello. ${ }^{121}$

Unfortunately, there was no consensus on the legal basis for characterizing the environmental destruction as wrongful. The United States, for example, labeled the actions militarily unnecessary and, therefore, a violation of the Fourth Geneva Convention. ${ }^{122}$ It also cited them as violations of the customary international law rules of proportionality and necessity. Other states referred to Protocol I and ENMOD, while a third group suggested that peacetime environmental law carried forward into

115. See Note Verbale Dated 5 July 1991 from the Charge D'affaires of the Permanent Mission to Jordan to the United Nations Secretary General, U.N. GAOR, 46th Sess., Annex, para. 2, U.N. Doc. A/46/141 (1991).

116. See id. para. 3 .

117. See Summary Record of the 18th Meeting, U.N. GAOR 6th Comm., 46th Sess., 18th mtg., at 3, U.N. Doc. A/C.6/46/SR.18 (1991).

118. See Summary Record of the 19th Meeting, U.N. GAOR 6th Comm., 47th Sess., 19th mtg., at 5, U.N. Doc. A/C.6/47/SR.19 (1992).

119. See id. at 8-9.

120. S.C. Res. 687, U.N. SCOR, 45th Sess., 2981st mtg., para. 16, U.N. Doc. S/RES/687 (1991).

121. See infra Section III.D.

122. For discussion of the relevant sections of the Geneva Convention IV, see infra Subsection III.C.2. 
periods of hostilities and applied in the case of the Gulf War. ${ }^{123}$

Further disagreement arose in the Sixth Committee over whether new law was needed. The United States vocally opposed a new convention on the grounds that none of the proposals made to date adequately balanced the desire for environmental protection with the need to ensure against an erosion of self-defense rights under article 51 of the U.N. Charter. ${ }^{124}$ The opposing view emphasized that the Gulf War had demonstrated convincingly the need for further development of the legal regime. Additional unresolved issues included dispute resolution, the applicability of peacetime norms during armed conflict, damage assessment processes, and the imposition of liability. ${ }^{125}$

As this debate unfolded, the ICRC was planning its twenty-sixth International Conference, at which one topic was to be environmental damage during warfare. When the conference was later canceled, the ICRC decided to convene a meeting of experts in April 1992 to consider the issue. ${ }^{126}$ The United Nations took advantage of this opportunity by asking the ICRC to study and report back on current activities in the field. ${ }^{127}$

In its 1992 report to the Secretary General, the ICRC noted that experts generally had concluded that, despite a "number of gaps in the rules currently applicable," the best approach was not a new body of law. ${ }^{128}$ Concurring with the experts, the ICRC recommended efforts to convince more states to accede to existing instruments (an obvious reference to Protocol I), enact implementing legislation at the domestic level, and observe their international obligations. ${ }^{129}$ It also set forth what it believed to be the current law in the area: Hague IV, ${ }^{130}$ the Fourth Geneva Convention, ${ }^{131}$ Protocol I, ENMOD, the Gas Protocol of $1925,{ }^{132}$ the Biological Weapons Convention of $1972,{ }^{133}$, the Conventional Weapons Convention, ${ }^{134}$ and the draft

123. See Summary Record of the 18th Meeting, supra note 117, at 2-12.

124. See id. at 9.

125. See id. at 2-12. On this and the issue of the basis for unlawfulness of the Iraqi actions, see Virginia Morris, Protection of the Environment in Wartime: The United Nations General Assembly Considers the Need for a New Convention, 27 INT'L LAW. 775, 777-79 (1993).

126. The cancellation was required due to a dispute over the attendance of a Palestinian representative. See Verwey, Protection, supra note 13, at 12.

127. See G.A. Res. 417, U.N. GAOR, 46th Sess., Supp. No. 49, at 319, U.N. Doc. A/46/49 (1991).

128. See Protection of the Environment in Times of Armed Conflict: Report of the Secretary General, U.N. GAOR, 47th Sess., para. 40, U.N. Doc. A/47/328 (1992) [hereinafter 1992 Secretary General Report].

129. See id.

130. Convention Respecting the Laws and Customs of War on Land, Oct. 18, 1907, 36 Stat. 2277, 205 Consol. T.S. 277 [hereinafter Hague IV].

131. Geneva Convention IV, supra note 10.

132. Protocol for the Prohibition of the Use in War of Asphyxiating, Poisonous or Other Gases, and of Bacteriological Methods of Warfare, June 17, 1925, 26 U.S.T. 571, 14 I.L.M. 49 (1975) [hereinafter Gas Protocol]. The Gas Protocol entered into force for the United States in 1975.

133. Convention on the Prohibition of the Development, Production and Stockpiling of Bacteriological (Biological) and Toxin Weapons and on Their Destruction, Apr. 10, 1972, 26 U.S.T. 583, 11 I.L.M. 310 [hereinafter Biological Weapons Convention].

134. Convention on Prohibitions or Restrictions on the Use of Certain Conventional Weapons Which May Be Deemed To Be Excessively Injurious or To Have Indiscriminate Effects, Oct. 10, 1980, 19 I.L.M. 1524 [hereinafter Conventional Weapons Convention]. The United States ratified this convention in March 1995. Interestingly, there has been relatively little attention paid to the Convention's preamble: 
Chemical Weapons Convention. ${ }^{135}$ The customary international law of war principles of military necessity and proportionality, as well as the general principle that methods and means of warfare are not unlimited, were said to be applicable, and peacetime environmental law was said to remain in force during armed conflict, particularly between belligerents and neutrals. ${ }^{136}$

Though the ICRC recommended against further codification, it did highlight four topics that it felt required further clarification. First, it recommended harmonizing the understanding of terms common to Protocol I and ENMOD. Both use the terms "widespread," "long-term," and "severe," but the terms are subject to varying interpretations-a situation that invites confusion in their application. The ICRC also recommended inquiry into the relationship between international environmental law (primarily peacetime law) and the law of armed conflict (labeled "humanitarian law" by the ICRC). Associated with that inquiry was the need to determine the obligations of belligerents toward nonbelligerents with regard to environmental damage occurring in the territory of the latter. Finally, the ICRC called for a study of how the natural environment per se might be better protected. ${ }^{137}$

The Sixth Committee reviewed this report. Interestingly, the United States and Jordan submitted a joint memorandum of law to the Chairman of the Sixth Committee for use during the Committee's consideration. ${ }^{138}$ Though not as comprehensive as the ICRC's report, the memorandum set forth an identical set of core prescriptions: Hague IV, Geneva Convention IV, and customary law principles such as military necessity, proportionality, and discrimination. Additionally, the memorandum mentioned Protocol I and the ENMOD as binding on parties to those agreements. ${ }^{139}$

Not long after the Sixth Committee's proceedings began, it became clear that the disputes over the law's sufficiency remained:

"[I]t is prohibited to employ methods or means of warfare which are intended, or may be expected, to cause widespread, long-term and severe damage to the natural environment." Id. pmbl. In a reservation, France noted that the provision only applies to countries that have ratified Protocol I Additional, which contains identical language. Protocol III of the Conventional Weapons Convention governs incendiary weapons. See Protocol on Prohibitions or Restrictions on the Use of Incendiary Weapons (Protocol III), 19 I.L.M. 1534 (1980) [hereinafter Protocol III]. Its restrictions cover attacks on "forests or other kinds of plant cover ... except when such natural elements are used to cover, conceal or camouflage combatants or other military objectives or are themselves military objectives." Id. art. 2, para. 4. The United States did not ratify Protocol III. See discussion infra Subsection III.C.3.

135. Convention on the Prohibition of the Development, Production, Stockpiling and Use of Chemical Weapons and on Their Destruction, Jan. 13, 1993, 32 I.L.M. 800 [hereinafter Chemical Weapons Convention]. This convention was transmitted to the Senate in November 1993, but at the time this Article was written, had not yet been ratified. See <http:/www.un.org/Depts/Treaty >.

136. See 1992 Secretary General Report, supra note 128, para. 56. The experts compared international environmental law with human rights law. As in the latter, certain provisions of the former were to be inapplicable during armed conflict. Nevertheless, the core provisions, analogized to "hard core" provisions in human rights law, remain in effect. See id. The participants recommended that any new treaty dealing with international environmental law specifically address the issue of applicability during armed conflict. See id.

137. See id. para. 43.

138. Protection of the Environment in Times of Armed Conflict, Letter from the Permanent Missions of the Hashemite Kingdom of Jordan and of the United States of America to the Chairman of the Sixth Committee (Sept. 28, 1992), U.N. GAOR 6th Comm., 47th Sess., Agenda Item 136, U.N. Doc. A/C.6/47/3 (1992).

139. See id. at 2-3. 
[S]ome States felt that the existing rules were sufficient and that what was needed was ensuring greater compliance with them. However, most of the States represented thought it also necessary to clarify and interpret the scope and content of some of those rules, and even to develop other aspects of the law relating to the protection of the environment in times of armed conflict. These include the need for better protection of the environment as such; the need for stricter application of the principle of proportionality (and, to this end, for a more precise definition of its scope in specific situations), the importance of defining more precisely the threshold of application of the rules; the need for a clear decision regarding the applicability in wartime of provisions of international environmental law; and the advisability of setting up a mechanism to sanction breaches thereof. ${ }^{140}$

All suggestions for a "complete overhaul of existing law" were rejected. ${ }^{141}$

Based on its review of the initial ICRC report, the Sixth Committee recommended that the ICRC continue its work in the field and again report its conclusions. By resolution, the General Assembly agreed. ${ }^{142}$ General Assembly Resolution $47 / 37$ also called for states to become party to the relevant international agreements, a clear reference to Protocol I and its "rejection" by most of the key players in the international arena. Moreover, it contained a plea for compliance with the environmental law of armed conflict and urged states to incorporate its provisions into their law of war manuals. The resolution expressed concern about the environmentally destructive Iraqi actions during the Gulf War, and noted "that existing provisions of international law prohibit such acts." ${ }^{43}$

The General Assembly resolution also stressed the illegality of environmental destruction unjustified by military necessity. ${ }^{144}$ This condemnation, unanimously adopted by the General Assembly, has been proffered as "of special interest" to those who expressed concern in the Gulf War's aftermath that "the international legal structure was not sufficiently developed to deal with problems such as these." ${ }^{145}$ Despite this assertion, at the time there was great difference of opinion regarding which law was applicable and how to remedy the applicable law's purported shortcomings. The fact that all could agree that the acts violated some international legal norm hardly demonstrates that the relevant law is sufficiently developed.

Retasked, the ICRC began a second round of consultations. It first considered whether to draft new law or look for ways to improve compliance with existing legal norms. Upon the advice of the experts it had gathered to

140. United Nations Decade of International Law: Report of the Secretary-General on the Protection of the Environment in Times of Armed Conflict, U.N. GAOR, 48th Sess., Provisional Agenda Item 144, paras. 14-15, U.N. Doc. A/48/269 (1993) [hereinafter 1993 Secretary General Report]. The Sixth Committee debates produced many suggestions for improving the legal regime. They addressed the need for harmonization of interpretation and clarification of the norms, the possibility of new law in the field, and potential improvements to the implementation and enforcement regimes, such as fact-finding committees or an international criminal court. See Summary Record of the 19th Meeting, supra note 118; Summary Record of the 9th Meeting, U.N. GAOR 6th Comm. 47th Sess., 9th mtg., U.N. Doc. A/C.6/47/SR.9 (1992); Summary Record of the 8th Meeting, U.N. GAOR 6th Comm., 47th Sess., 8th mtg., U.N. Doc. A/C.6/47/SR.8 (1992).

141. See 1993 Secretary General Report, supra note 140, para. 15.

142. See G.A. Res. 47/37, U.N. GAOR 6th Comm., 47th Sess., Agenda Item 136, U.N. Doc. A/RES/47/37 (1993).

143. Id. at 2 .

144. See id. On the issues of military necessity and wantonness, see infra Subsection III.B.1.

145. John H. McNeill, Protection of the Environment in Times of Armed Conflict: Environmental Protection in Military Practice, 1993 HAGUE Y.B. INT'L L. 75, 77. 
consider the issue, the ICRC chose the latter course of action. In particular, it decided to develop guidelines for wartime environmental protection that could be adopted into instructions that individual countries would issue to their armed forces. ${ }^{146} \mathrm{By}$ its third meeting, the ICRC completed a draft, the ICRC Guidelines, which it forwarded to the United Nations. ${ }^{147}$ The General Assembly, in turn, invited member states to review and comment upon the ICRC Guidelines. It also welcomed the intention of the ICRC to consider member states' comments about the Guidelines, make appropriate changes, and resubmit them. ${ }^{148}$ These steps were completed by 1994, at which time the General Assembly, without formally approving the Guidelines, urged all states to consider incorporating them into their law of armed conflict directives. ${ }^{149}$

Essentially a restatement of the law of war provisions that the ICRC had cited in its report to the Secretary General two years earlier, the Guidelines begin with the assertion that "existing international legal obligations and ... State practice"150 make up their foundation. In fact, however, they rely heavily on the Protocol I environmental articles that many countries, in particular the United States, oppose. Nevertheless, given the growing number of states that are Protocol I parties, it would be fair to cite its prescriptions as the direction in which the environmental law of war is heading. ${ }^{151}$ As for state practice, the ICRC position is on firm ground. Whether or not Protocol I is binding on nonsignatories, the only country that arguably has violated articles $35(3)$ and 55 in a major conflict during the last decade is Iraq, and it suffered nearly unanimous condemnation for its conduct.

In addition to Protocol I, the Guidelines refer to a number of other familiar sources of law: Hague VIII (submarine mines), ${ }^{152}$ Hague IV, Geneva IV, the Conventional Weapons Convention, the Convention for the Protection of Cultural Property, ${ }^{153}$ and ENMOD. They also emphasize the centrality of classic law of war principles such as the rule of proportionality; ${ }^{154}$ note that peacetime environmental law remains applicable

146. See Gasser, supra note 98 , at 640 .

147. See 1993 Secretary General Report, supra note 140.

148. See G.A. Res. 48/30, U.N. GAOR, 48th Sess., at 2, U.N. Doc. A/RES/48/30 (1993). The draft resolutions are U.N. GAOR, 47th Sess., U.N. Doc. A/C.6/47/L.2 (1992); U.N. GAOR, 47th Sess., U.N. Doc. A/C.6/47/L.2/Rev. 1 (1992).

149. See G.A. Res. 49/50, U.N. GAOR, 49th Sess., U.N. Doc. A/RES/49/50 (1995). The Guidelines are reprinted in U.N. GAOR, 49th Sess., Annex, Agenda Item 139, at 49-53, U.N. Doc. A/49/323 (1994) [hereinafter ICRC Guidelines]; Gasser, supra note 98, at 641-43.

150. ICRC Guidelines, supra note 149 , para. 1.

151. As of November 30, 1996, there were 145 parties to Protocol I. See $<$ http://gvalnex1.icrc.org > . Among the parties with whom the United States has close military ties are Australia, Canada, Egypt, Germany, Greece, Korea, and the Netherlands. The Russian Federation is also a party. See id.

152. Convention Relative to the Laying of Automatic Submarine Contact Mines, 36 Stat. 2332 (1907) [hereinafter Hague VIII].

153. Convention for the Protection of Cultural Property in the Event of Armed Conflict, May 14, 1954, 249 U.N.T.S. 240 [hereinafter Convention for the Protection of Cultural Property], reprinted in THE LAwS OF ARMED CONFLICTS 745 (Dietrich Schindler \& Jiri Toman eds., 1988).

154. For example:

[T] he general principles of international law applicable in armed conflict-such as the principle of distinction and the principle of proportionality-provide protection to the environment. In 
during armed conflict to the extent that it is consistent with the law of armed conflict; ${ }^{155}$ and include what has become known as a "Martens clause."156 Considered a general principle of international law, this latter provision provides that "[i]n cases not covered by rules of international agreements, the environment remains under the protection and authority of principles of international law derived from established custom, from the principles of humanity and from the dictates of public conscience." 157 In other words, when its criteria are met, the clause denies offenders the argument that their conduct is not actionable because it falls outside applicable international agreements.

Specific prohibitions in the ICRC guidelines include those against destroying the environment when not justified by military necessity; ${ }^{158}$ attacking forests with incendiary weapons unless the area is being used for cover, concealment, or camouflage, or unless the forests or plant cover are legitimate targets in themselves; ${ }^{159}$ and attacking objects on which the civilian population depends for survival (when carried out to deny civilians those objects). ${ }^{160}$ Particular types of historic monuments and places of worship are forbidden targets, ${ }^{161}$ as are installations or works containing dangerous forces. ${ }^{162}$ In a novel provision, the experts recognized the environmental dangers of mines by prohibiting their indiscriminate laying. ${ }^{163}$ As might be expected, the "widespread," "long-term," and "severe" formula of Protocol I and ENMOD makes another appearance, ${ }^{164}$ and reprisals

particular, only military objectives may be attacked and no methods or means of warfare which cause excessive damage shall be employed.

ICRC Guidelines, supra note 149, para. 4.

155. See id. para. 5 .

156. The clause is named after the Russian representative who proposed it at the Hague Conference of 1899 .

157. ICRC Guidelines, supra note 149, para. 7.

158. See id. para. 8 (citing Hague IV, supra note 130, art. 23(g); Geneva Convention IV, supra note 10, arts. 53, 147; Protocol I, supra note 8, arts. 35, para. 3, 55); see also infra Subsection III.C.3.

159. See ICRC Guidelines, supra note 149, para. 9(a) (citing Conventional Weapons Convention, supra note 134; Protocol III, supra note 134).

160. See id. para. 9(b) (citing Protocol I, supra note 8, art. 54).

161. See id. para. 9(d) (citing Convention for the Protection of Cultural Property, supra note 153; Protocol I, supra note 8, art. 53).

162. See id. para. 9(c) (citing Protocol I, stupra note 8, art. 56). Note that the United States is opposed to this provision in Protocol I. See infra Subsection III.C.3.

163. The Guidelines state:

The indiscriminate laying of landmines is prohibited. The location of all pre-planned minefields must be recorded. Any unrecorded laying of remotely delivered, non-self neutralizing land mines is prohibited. Special rules limit the emplacement and use of naval mines.

ICRC Guidelines, supra note 149, para. 10 (citing Conventional Weapons Convention, supra note 134, art. 3; Protocol I, supra note 8, art. 51, paras. 4-5; Hague VIII, supra note 152).

164. The ICRC Guidelines provide:

Care shall be taken in warfare to protect and preserve the natural environment. It is prohibited to employ methods or means of warfare which are intended, or may be expected, to cause widespread, long-term and severe damage to the natural environment and thereby prejudice the health or survival of the population.

ICRC Guidelines, supra note 149, para. 11. Note that the ICRC has elected to include the anthropocentrically based prescription found in article 55 of Protocol I, rather than the more heavily intrinsic value prohibition of article 35(3). For discussion of this distinction, see infra Subsection III.C.3. 
against the environment are proscribed. ${ }^{165}$ These latter provisions are certain to hinder universal adoption, for both are derived from controversial Protocol I articles. Finally, the responsibility to "prevent and, where necessary, to suppress and to report to competent authorities" breaches of the rules is imposed on military commanders. ${ }^{166}$ Using nondiscretionary language, the Guidelines provide that "[i]n serious cases, offenders shall be brought to justice." 167 It will be instructive to watch the progress of adoption, if only because of the relationship between the Guidelines and controversial Protocol I prescriptions.

In fact, increased awareness of warfare's environmental implications slowly is beginning to be reflected where it will have its greatest practical effect-in guides for planners, warfighters, and operational lawyers. The German law of war manual is among the most progressive. ${ }^{168}$ Not only does this 1992 document provide for basic protections based on such principles as military necessity, unnecessary suffering, and distinction, but it also includes prohibitions that track those found in Protocol I and ENMOD. Specifically, article 401 provides that "[i]t is particularly prohibited to employ means or methods of warfare which are intended or of a nature ... to cause widespread, long-term and severe damage to the natural environment." 169 The manual contains a similar provision with regard to naval warfare. What is most noteworthy about the German manual is that it clarifies the ENMOD and Protocol I terminology that is the source of much controversy. In article 403 , the manual states that

\footnotetext{
"widespread", "long-term" and "severe" damage to the natural environment is a major interference with human life or natural resources which considerably exceeds the battlefield damage to be regularly expected in war. Damage to the natural environment by means of warfare and severe manipulation of the environment as a weapon are likewise prohibited. ${ }^{170}$
}

The extent to which this attempt to square the terminological circle of these two agreements will prove successful remains to be seen.

Another example of a law of war guide that addresses the environment is the San Remo Manual. ${ }^{171}$ Drafted for the International Institute of Humanitarian Law by a group of distinguished experts between 1988 and 1994 as a "restatement" of the international law of armed conflict at sea, this influential guide takes a different approach than its German counterpart. Whereas the German Manual adopts the phraseology of Protocol I and

165. See id. para. 13 (citing Protocol I, supra note 8, art. 55, para. 2).

166. Id. para. 20.

167. Id. para. 20 (citing Geneva Convention IV, supra note 10, arts. 146-147; Protocol I, supra note 8 , arts. 86-87).

168. FEDERAL MiNISTRY OF DEFENCE OF THE F.R.G., HUMANITARIAN LAW IN ARMED CONFLICTS: MANUAL (1992) [hereinafter GERMAN MANUAL].

169. Id. para. 401.

170. Id. para. 403 .

171. INTERNATIONAL INST. OF HUMANITARIAN LAW, SAN REMO MANUAL ON INTERNATIONAL LAW APPliCABle to ARMEd Conflicts at SEA (Louise Doswald-Beck ed., 1995) [hereinafter SAN REMo]. The group assembled to draft the manual included Professor Salah El-Din Amer, Louise Doswald-Beck, Vice Admiral (ret.) James H. Doyle, Jr., Commander William J. Fenrick, Christopher Greenwood, Professor Horace B. Robertson, Jr., Gert-Jan F. Van Hegelsom, and Dr. Wolff Heintschel von Heinegg. 
ENMOD, the San Remo Manual employs the "due regard" standard of care found in the Law of the Sea Convention. ${ }^{172}$ Paragraph 44 of the manual provides that "methods and means of warfare should be employed with due regard for the natural environment taking into account the relevant rules of international law. Damage to or destruction of the natural environment not justified by military necessity and carried out wantonly is prohibited." 173 Although this provision is less stringent than those found in Protocol I and ENMOD, it may be more appropriate in the naval context because "due regard" is a familiar concept in maritime law and practice. Additionally, Protocol I was never intended to encompass naval warfare. ${ }^{174}$

None of the primary U.S. law of war manuals highlights environmental concerns to any significant degree. Current Army and Air Force versions are simply too dated to have focused on the issue. ${ }^{175}$ However, while the Navy's old manual was also silent on this issue, ${ }^{176}$ the newly published Navy manual does mention the topic. ${ }^{177}$ Since it represents the most current expression of U.S. policy on the subject, the manual's sole environmental provision merits quotation in its entirety:

\begin{abstract}
It is not unlawful to cause collateral damage to the natural environment during an attack upon a legitimate military objective. However, the commander has an affirmative obligation to avoid unnecessary damage to the environment to the extent that it is practicable to do so consistent with mission accomplishment. To that end, and as far as military requirements permit, methods or means of warfare should be employed with due regard to the protection and preservation of the natural environment. Destruction of the natural environment not necessitated by mission accomplishment and carried out wantonly is prohibited. Therefore, a commander should consider the environmental damage which will result from an attack on a legitimate military objective as one of the factors during targeting analysis. ${ }^{178}$
\end{abstract}

It will be particularly interesting to see how the new U.S. multiservice law of war manual, on which the Army has taken the lead, handles environmental matters. If the most recent edition of the Army's excellent Operational Law Handbook is any indication, the manual will display a

172. See United Nations Convention on the Law of the Sea, Dec. 10, 1982, U.N. Doc. A/CONF.62/122, 21 I.L.M. 1261 [hereinafter LOS Convention]. For instance, article 58(3) provides that "[i]n exercising their rights and performing their duties under this Convention in the exclusive economic zone, States shall have due regard to the rights and duties of the coastal State." Id. art. 58, para. 3.

173. SAN REMO, supra note 171 , para. 44.

174. On the applicability of Protocol I to naval warfare, see infra Subsection III.C.3. At the meeting there was significant debate over whether to use a "due regard" or "respect for" standard. According to the Rapporteur, some of the participants wanted to use the latter to maximize protection of the environment. See SAN REMo, supra note 171, para. 44.9. However, the "due regard" standard was eventually agreed upon because it was already in use in the LOS Convention and because it "more appropriately expressed the balance that must exist between the right of the States involved in naval conflict at sea to use lawful methods and means of warfare on the one hand, and the duty of such States to protect the marine environment on the other." Id.

175. See DEPARTMENT OF THE AIR FORCE, INTERNATIONAL LAW-THE CONDUCT OF ARMED CONFLICT AND AIR OPERATIONS (Pamphlet No. 110-31, 1976) [hereinafter AFP 110-31]; DEPARTMENT OF THE ARMY, THE LAW OF LAND WARFARE (Field Manual 27-10, 1956) [hereinafter AFM 27-10].

176. DEPaRTMENT OF THE NAVY, THE COMMANDER'S HaNDBOOK ON THE LAW OF NAVAL OPERATIONS (Navy Warfare Publication 9-Rev. A, 1989).

177. Note that both the Marine Corps and the Coast Guard have agreed to the new manual's use in a multiservice format.

178. DEPARTMENT OF THE NAVY, COMMANDER'S HANDBOOK ON THE LAW OF NAVAL OPERATIONS para. 8.13 (Naval Warfare Publication 1-14M, 1996) [hereinafter NWP 1-14M]. 
growing awareness of, and commitment to, environmental protection during warfare. ${ }^{179}$ The handbook devotes an entire chapter to the subject of the environmental law of war, citing to sources that were referenced in the Secretary General's Report and the Jordanian-U.S. memorandum discussed previously. However, what is noteworthy about the handbook is that in discussing military necessity, it directs judge advocates to "pay particular attention to (1) the geographical extent (how widespread the damage will be), (2) the longevity, and the (3) severity of the damage upon the target area's environment." 180 Significantly, these three factors mirror those found in the Protocol I provisions to which the United States objects. The handbook also notes that while the United States is not a party to the protocol, U.S. forces need to be sensitive to the implications of combined operations with the military forces of states that are parties to the protocol. This is superb advice of very practical warfighting import.

Finally, mention should be made of a NATO initiative in the environmental field that has borne little fruit thus far. In January 1994, Norwegian, German, and Canadian representatives recommended that NATO's Committee on the Challenges of Modern Society conduct a pilot study on environmental protection. Though most delegations received the proposal favorably, two expressed a concern that the study might have negative consequences for military effectiveness. At present, the proposal has been placed on hold pending further assessment of its merits. ${ }^{181}$ Whether it resurfaces will be an excellent indicator of shifts in attitudes toward the place of environmental concerns in combat.

Do these various steps forward portend an emergent military sensitivity to the environmental law of war? That the Office of the Secretary of Defense (OSD) sponsored The Symposium on the Protection of the Environment During Armed Conflict and Operations Other Than War at the Naval War College in September 1995 suggests that the answer is yes. Despite heightened interest in such protection, the prevailing view-that no effort to fashion new law, or to codify existing law, is needed-remains firmly entrenched. It was certainly the general consensus of the scholars, warfighters, and policymakers who gathered in Newport. ${ }^{182}$ That the dominant cognitive perspective remains

179. See INTERNATIONAL \& OPERATIONAL LAW DEP'T, U.S. ARMY, OPERATIONAL LAW HANDBOOK (1995) [hereinafter OPERATIONAL LAW HANDBOOK]. The Handbook provides:

Protecting the environment has become steadily more important during the past several decades. The international community is increasingly vigilant in its oversight of the environmental consequences of military operations. . . . Failure to comply with environmental law can jeopardize current and future operations, generate domestic and international criticism, produce costly litigation, and even result in personal liability of both the leader and the individual soldier.

Id. at 5-1.

180. Id. at 5-4.

181. This initiative is described in Dieter Fleck, Protection of the Environment During Armed Conflict and Other Military Operations: The Way Ahead, Paper Presented at the Symposium on the Protection of the Environment During Armed Conflict and Operations Other Than War, in NWC SYMPOSIUM PAPERS, supra note 13 (manuscript at 7-8, on file with The Yale Journal of International Lav). at 5 .

182. However, it was not the unanimous consensus; some participants called for new law. See id. 
overwhelmingly anthropocentric is also clear. The comments of the ICRC's Hans-Peter Gasser may reflect the prevailing attitude. Speaking at the 1991 London Conference in his personal capacity, he noted that

\begin{abstract}
the ICRC does not look so much at the environment as such but more at the environment in the context of and around human beings. As you know the Geneva Conventions are geared essentially to the protection and safeguarding of human beings in times of armed conflict .... [The environmental provisions of Geneva law] protect the environment for human beings-when both civilians and combatants are affected. ${ }^{183}$
\end{abstract}

This perspective could apply equally to the law beyond the Geneva Conventions (and Protocol I) and to international attitudes other than those of the ICRC. Having set the law within its proper historical context, it is appropriate to turn to an analysis of the law and the effect of the various perspectives on it.

\title{
III. WHERE ARE WE?
}

\section{A. Peacetime Prescriptions}

Since the Gulf War, there has been widespread recognition that the role of peacetime environmental prescriptions during armed conflict merits further study. ${ }^{184}$ Part of the uncertainty in deciding which prescriptions apply derives from the context within which this body of law was intended to operate. As one commentator has perceptively noted, environmental law emerged primarily in response to major accidents such as the Torrey Canyon disaster and Chernobyl. ${ }^{185}$ It was never intended to govern the intentional infliction of damage to another's territory; in several cases, the issue has been resolved explicitly through treaty provisions excluding applicability during armed conflict. ${ }^{186}$ Yet to the extent that international actors are liable for negligent actions (or even nonnegligent actions, in cases of strict liability) that damage the environment, should they not also be held liable when they intentionally set out to realize the forbidden end? From a moral perspective,

183. Awn Al-Khasaweh, Round-Table Session I, General Principles and Methods for Executing a New Convention, in ENVIRONMENTAL PROTECTION AND THE LAW OF WAR, supra note 94, at 111 (statement of Hans-Peter Gasser).

184. The matter was addressed in both the ICRC and Munich Conference reports, whose specific conclusions are nearly interchangeable. The ICRC experts opined that environmental law remained largely applicable during hostilities and that core environmental treaties needed to be analyzed to assess applicability. See 1992 Secretary General Report, supra note 128, para. 56. The Munich Conference went slightly further by noting that environmental law remained in force as between belligerents and nonbelligerents, but that the rules concerning its effect vis-à-vis opposing belligerents needed to be clarified. See Munich Report, supra note 100 , para. 6 . The consensus view is that while some peacetime environmental law may certainly remain in effect during hostilities, no ready-made catalogue of applicable law exists, nor are the rules for applicability well defined.

185. See Anthony Leibler, Deliberate Wartime Environmental Damage: New Challenges for Intemational Law, 23 CAL. W. INT'L L.J. 67, 69-70 (1992).

186. See, e.g., International Convention for the Prevention of Pollution of the Sea by Oil, May 12, 1954, art. 19, 12 U.S.T. 2989, 327 U.N.T.S. 3 ("In case of war or other hostilities [a party may] suspend the operation of the whole or any part of the present convention ....."). 
the response may well be that they should; legally, things look much hazier. ${ }^{187}$

The uncertainty is of consequence, for the bulk of international environmental law is found in sources outside the law of armed conflict. Selected elements of the former will be surveyed in the following sections. However, much more important than the issue of what law applies is the issue of when it applies. What are the "rules" for applying peacetime norms during armed conflict? Without understanding these rules, any consideration of specific scenarios that might involve peacetime norms will prove futile because most environmental agreements fail to address the issue directly. Therefore, the inquiry into peacetime prescriptions must begin with the issue of applicability.

\section{Applicability}

In the classic understanding, treaties did not survive the initiation of hostilities. War was a state of affairs that existed beyond the realm of international law and relations. Indeed, it represented the breakdown of those entities. However, the more modern view is that war is a continuation of interstate relations and, thus, subject to legal limits. This was the position that Justice Benjamin Cardozo expressed in the landmark case of Techt $v$. Hughes. ${ }^{188}$ According to Justice Cardozo, "international law to-day does not preserve treaties or annul them, regardless of the effects produced. It deals with such problems pragmatically, preserving or annulling as the necessities of war exact. It establishes standards, but it does not fetter itself with rules." 189

Within this contemporary approach, three camps may be discerned. ${ }^{190}$ The oldest school suggests that whereas certain relations animated by legal content might survive the outbreak of hostilities, treaties do not; a treaty relationship is inconsistent with a state of armed conflict. ${ }^{191}$ Its advocates point to the fact that no peacetime environmental convention specifically provides for applicability during hostilities as further support. ${ }^{192}$ On the

187. In his excellent article, Anthony Leibler notes that "to the extent that these laws apply to the negligent or careless pollution, it is logical to assume that they must certainly apply to deliberate pollution." Leibler, supra note 185 , at 70 . While it may in fact be logical, such a conclusion does not hold as a matter of international law. As will be discussed below, the existence of a state of armed conflict has much play on the issue.

188. 128 N.E. 185 (N.Y.), cert. denied, 254 U.S. 643 (1920).

189. Id. at 191 .

190. For an excellent discussion on which much of this analysis builds, see Jost Delbrück, War, Effect on Treaties, in 4 ENCYCLOPEDIA OF PUBLIC INTERNATIONAL LAW 311 (1982).

191. For example, one prominent scholar has noted that "[a]s a rule, bilateral treaties are terminated or suspended by the outbreak of a war unless they were concluded with the war in mind. The effects of multilateral treaties are also suspended between the adversaries unless they were concluded specifically with a view to the state of war." Michael Bothe, The Protection of the Environment in Times of Armed Conflict: Legal Rules, Uncertainty, Deficiencies and Possible Developments, 34 GERM. Y.B. INT'L L. 54, 59 (1991). He goes on to acknowledge, however, that "modern opinion . . . favors the non-suspension of certain types of obligations even between belligerents. It would appear that some basic rules relating to the environment might be counted among the latter obligations." Id.

192. See, e.g., Verwey, Additional Rules, supra note 13, at 11. 
other extreme are those who maintain that treaties do survive, except to the extent that they are by their specific nature inconsistent with hostilities. Examples of inconsistent agreements between opposing belligerents are status of forces agreements, alliance arrangements, and military aid treaties. A third approach takes the middle ground. Labeled the "theory of differentiation," it is contextual in nature and reflects an effort to balance the stability that international agreements offer with a realization that armed conflict may be at odds with the fulfillment of treaty obligations and rights. Notably, it acknowledges that treaties may concern parties other than belligerents. Thus, in determining whether an agreement survives, it is necessary to ask whether continued vitality is consistent with the larger context in which the agreement will operate.

The Vienna Convention on the Law of Treaties does little to resolve the matter. In article 73 , it simply states that "[t]he provisions of the present Convention shall not prejudge any question that may arise in regard to a treaty ... from the outbreak of hostilities." ${ }^{193}$ In the absence of a definitive statement of law, and in the face of disagreement over the effect of war on treaties, one must turn to logic and context to select from among the three approaches.

To argue sans plus that treaties become inoperative upon the start of hostilities is to suggest that war is really all that matters once it breaks out. However, many treaties are the expression of mutual interests wholly unrelated to the causes or effects of conflict. The first approach would, therefore, forfeit the mutual benefits that treaties might continue to provide to both parties. ${ }^{194}$ On the other hand, the second approach's claim of nearuniversal continued validity is unrealistic. States become involved in armed conflict for many different reasons. Some conflicts are the product of rational decisionmaking; some are not. Yet all wars are laden with emotion. Even aspects of ante bellum relations unrelated to the conflict are bound to be affected, a reality for which the law should account. The aim should be to preserve treaty regimes that can survive; to perpetuate artificially those that are destined to splinter will dilute the effect of those that might not.

Best fostering this aim and upholding international interests in global order is the third conceptual approach. It suggests certain conclusions about continued vitality that derive from the nature of the treaty at hand and the type of conflict underway. On the one hand, there are those agreements intended for armed conflict, such as the Geneva Conventions. Obviously, all such treaties survive; indeed, they may not even become operative until hostilities occur. Also surviving are treaties that expressly provide for continuance

193. Vienna Convention on the Law of Treaties, May 23, 1969, art. 73, 1155 U.N.T.S. 331,8 I.L.M. 679 [hereinafter Vienna Convention]. The Vienna Convention came into force in 1980, but, as of the date of this Article, has not been ratified by the United States. Nevertheless, most of its provisions are declaratory of customary international law.

194. For example, mutual safeguarding of straddling stocks of fish pursuant to article 63 of the Law of the Sea Convention benefits both sides by preserving a mutually important natural resource. See LOS Convention, supra note 172, art. 63 . 
during war. ${ }^{195}$ At the other end of the spectrum lie those treaties that either become inoperative by their own terms once armed conflict breaks out ${ }^{196}$ or are so obviously inconsistent with hostilities that they are $a$ priori deemed to terminate when hostilities commence. Military aid agreements are a good example.

The issue becomes much more difficult between the two extremes. However, given the goals underlying the theory of differentiation, it is possible to pose a series of questions that can help identify where along the continuum a treaty is likely to fall. Consider the following indicators of survivability. Bear in mind that these indicators apply contextually; it would be foolhardy to assess survivability apart from the actual situation in which the applicability issue arises.

(1) Does the treaty regulate private or public interests? Treaties governing purely private interests are more likely to survive, for citizens may continue to reap their benefits even after the outbreak of hostilities without damaging the state's interests. Since environmental treaty law performs both functions, a case-by-case analysis is required.

(2) Is the treaty multilateral or bilateral? Bilateral treaties are much more likely to be suspended or terminated. In contrast, multilateral treaties will generally remain operative between belligerent and nonbelligerent signatories. As between opposing belligerents, if the obligation or right involved has ramifications (collateral damage, if you will) that extend beyond the belligerents, then it is less likely to be suspended or terminated. This often will be the case with treaties that create international regimes for a shared good. ${ }^{197}$ Given the interconnectedness of the global environment, the survival of environmental obligations and rights is especially likely. ${ }^{198}$

(3) If a bilateral treaty is at issue, who is party to the treaty? If it is between belligerents, then it will almost surely be suspended or terminated. Conversely, bilateral treaties between a belligerent and nonbelligerent usually will remain in force. There are certain exceptions to this generalization; the most common is the legal principle of "fundamental changed circumstances"-rebus sic stantibus. This customary principle, codified in article 62(1) of the Vienna Convention on the Law of Treaties, holds that an unforeseen fundamental change of circumstances may justify termination or withdrawal when the anticipated circumstances constituted an "essential basis

195. See, e.g., General Act of the Berlin Conference Respecting the Congo, Feb. 26, 1885, 165 Consol. T.S. 485 (providing for freedom of navigation on Congo and Niger rivers); Convention Relating to the Non-fortification and Neutralization of the Aaland Islands, Oct. 20, 1921, 9 L.N.T.S. 211.

196. See, e.g., International Convention for the Prevention of Pollution of the Sea by Oil, supra note 186 (permitting parties to suspend operation of treaty either in whole or in part in event of war or other hostilities).

197. See, e.g., Convention on International Civil Aviation, Dec. 7, 1944, 61 Stat. 1180, 15 U.N.T.S. 295 (setting forth rules of air for nongovernmental aircraft).

198. Consider the case of the Kuwait Regional Convention for Cooperation on the Protection of the Marine Environment from Pollution, Apr. 24, 1978, 17 I.L.M. 511. This treaty, to which Bahrain, Iran, Iraq, Kuwait, Oman, Qatar, Saudi Arabia, and the United Arab Emirates are parties, provided for the establishment of the Regional Organization for the Protection of the Marine Environment (ROPME), headquartered in Kuwait. ROPME continued to operate during the Gulf War, with the participation of both Kuwait and Iraq, even though its staff elements did leave Kuwait during the Iraqi occupation. Furthermore, the organization was instrumental in the post-hostilities cleanup effort. 
of the consent" of the parties at the time of agreement and the effect of enforcing the treaty in the new circumstances would be to "radically transform" the unperformed obligations of one of the parties. ${ }^{199}$ There can be little debate about whether the outbreak of armed conflict constitutes a fundamental change of circumstances. In the environmental arena, though, a state of peace would probably not have been an essential basis of agreement, unless compliance with the environmental restrictions would hinder effective combat operations. If so, such restrictions would fall into the category of radically transformed unperformed obligations. This analysis is equally applicable to multilateral treaties. Note that an "aggressor" may not invoke fundamentally changed circumstances to excuse itself from treaty obligations, because the change in question cannot result from the breach of international obligations owed to other treaty parties. ${ }^{200}$ Thus, if the invoking party is in violation of article 2(4) of the U.N. Charter, it may not rely on article 62 of the Vienna Convention.

(4) Are treaty obligations and/or rights executed or executory? The finality of a treaty is a powerful indication that it should remain in effect. ${ }^{201}$ Only in extraordinary circumstances would it be disturbed, and such circumstances would generally involve issues of fraud, coercion, and the like-not the existence of armed conflict. ${ }^{202}$ Most environmental treaties, in contrast, are executory because they impose continuing obligations.

(5) What type of conflict is involved? Current legal perspectives on treaty survival were conceived of as operating in the context of robust warfare, that is, hostilities of relatively significant intensity and extended duration. Furthermore, they responded to a classic aggression/self-defense paradigm. Today, however, the United States and other major powers are most likely to find themselves involved in low-intensity, limited-duration military operations other than war (MOOTW) motivated by nondefensive considerations.

MOOTW-peacekeeping, peace enforcement, peacemaking, humanitarian intervention, humanitarian relief, etc.-should not be deemed to have the same effect on treaties as more traditional forms of combat. Warfare in the familiar sense is a breakdown in relations, followed by an aggressive act. In response, the "victim" state acts in self-defense. Normal relations have been supplanted by the desire to harm an opponent. Though the intent may not be malicious (for example, to force an enemy to come to his senses regarding the costs of aggression), harm nevertheless remains the objective. In MOOTW, on the other hand, the goal usually is to avoid having to harm an opponent, assuming

199. Vienna Convention, supra note 193, art. 62, para. 1. It is a contextual standard. Consider the Convention on International Trade in Endangered Species of Wild Fauna and Flora, July 1, 1975, 27 U.S.T. 1087, 12 I.L.M. 1085, an agreement which appears to have little relationship to armed conflict. of the case of an extremely poor (failing) state engaged in an armed struggle for survival? If endangered species were one of the state's few sources of funds, would that state be required to comply with the denunciation provisions set forth in the treaty, or would the conflict represent changed circumstances radically transforming the state's obligations?

200. See Vienna Convention, supra note 193, art. 62, para. 2.

201. For instance, in the Treaty of Peace Between the United States and Great Britain, the United States is acknowledged to be a free state. The provision binds all the King's successors. Treaty of Peace, Sept. 3, 1783, U.S.-Gr. Brit., art. 2, 8 Stat. 80.

202. On the grounds for invalidity of treaties, see Vienna Convention, supra note 193, arts. 46-53. 
one can be identified. There should therefore be a presumption in favor of continued legal relations among all parties. When this presumption proves unreasonable or impractical in specific circumstances, the fallback position should logically be a presumption favoring suspension over termination of the treaty. The avoidance of environmental damage fits well within this relatively benign perspective.

To summarize, the approach that best comports with the reality of armed conflict while fostering world order is one in which a presumption of survivability attaches to peacetime environmental treaties, absent either de facto incompatibility with a state of conflict or express treaty provisions providing for termination. That said, the issue is best analyzed on a case-bycase basis. Particularly important is an awareness that urging the continued validity of treaties that, for practical purposes, are inconsistent with the existence of belligerent relations may be counterproductive to maintaining survivable treaty regimes. Finally, in assessing whether war has rendered treaty obligations void, voidable, suspended, or suspendable, it is essential to ask to whom the treaty obligations apply, for a key criterion is whether the treaty is between belligerents or between a belligerent and a nonbelligerent.

\section{Substantive Norms}

Those hoping to find comprehensive peacetime limits on environmental damage either in customary law or in the decisions of international adjudicative bodies will be disappointed. Instead, the prolific output of various international bodies, particularly the United Nations, has been primarily hortatory and aspirational in nature. As will become clear, it is only with great reluctance that states surrender sovereign prerogatives over the use of, and activities within, their territory. Thus, international instruments that have been agreed upon tend to be either nonbinding or narrowly crafted.

The beginning of the modern international environmental effort can be traced to the Stockholm Conference of 1972. Attended by representatives of over 100 countries, the U.N.-sponsored gathering produced two hortatory documents: a Declaration on the Human Environment ${ }^{203}$ and an Action Plan. ${ }^{204}$ Principle 21 serves as the Declaration's capstone. Reiterating the most basic premise of international environmental law, it provides:

States have, in accordance with the Charter of the United Nations and the principle of international law, the sovereign right to exploit their own resources pursuant to their own

203. United Nations Conference on the Human Environment, Stockholm Declaration on the Human Environment, June 16, 1972, U.N. Doc. A/CONF.48/14 (1972), revised by U.N. Doc. A/CONF.48/14/Corr.1 (1972), reprinted in 11 I.L.M. 1416 [hereinafter Stockholm Declaration]. The Declaration sets forth 26 guiding principles for crafting international environmental prescriptions. It asserts that there is a "fundamental right to freedom, equality and adequate conditions of life, in an environment of a quality that permits a life of dignity and well-being." Id. princ. 1. This right contains the corollary duty to "protect and preserve the environment for present and future generations." Id. Other principles address such matters as the relationship between underdevelopment and the environment, and liability and compensation. See id. princs. 9, 22.

204. United Nations Conference on the Human Environment, Action Plan for the Human Environment, U.N. Doc. A/CONF.48/14 (1972), reprinted in 11 I.L.M. 1421 (adopting 109 recommendations on such matters as management of global environment and environmental assessment). 
environmental policies, and the responsibility to ensure that activities within their jurisdiction or control do not cause damage to the environment of other States or of areas beyond the limits of national jurisdiction. 205

The principle thereby recognizes the tension between sovereignty and international environmental law, and attempts to balance the two. The final clause of the principle also suggests extending state responsibility to acts that cause environmental damage in the global commons, such as the high seas. ${ }^{206}$ Finally, though the Declaration does not address war per se, ${ }^{207}$ principle 26 emphasizes that " $[\mathrm{m}] \mathrm{an}$ and his environment must be spared the effects of nuclear weapons and all other means of mass destruction." 208 Thus, at this early point, consideration of the effect of warfare on the environment centered less on the fact of an impact than it did on the quantum of damage that could be caused-a very anthropocentric approach.

Although it did not generate new law, the Stockholm Declaration certainly indicated where international attitudes were headed in 1972. The environment was now acknowledged as a separate entity, but legal norms affording it protection continued to employ balancing tests. The next major environmental effort came ten years later when the World Conservation Union issued the World Charter for Nature, a document promptly adopted by the U.N. General Assembly, albeit with minor modifications. ${ }^{209}$ Of course, a General Assembly resolution, like the Stockholm Declaration, is only hortatory and aspirational. Nevertheless, it broadly articulates the standards influencing assessments of environmentally destructive conduct. ${ }^{210}$

With regard to extending peacetime norms to armed conflict, the Charter presents five key principles. ${ }^{211}$ The most important, principle 5, states that "[n]ature shall be secured against degradation caused by warfare or other hostile activities."212 Building on this aspiration in the section on implementation is principle 20 , a provision that could apply equally to times of peace and war: "Military' activity damaging to nature shall be

205. Stockholm Declaration, supra note 203, princ. 21.

206. The conference sped establishment of the United Nations Environment Programme (UNEP). Created in 1973, UNEP is responsible for coordinating U.N. activities involving the environment. It is also charged with pursuing agreement on international environmental treaties such as the Vienna Convention for the Protection of the Ozone Layer, Mar. 22, 1985, T.I.A.S. No. 11,097, 26 I.L.M. 1529 [hereinafter Ozone Convention].

207. Stephanie Simonds argues that principle 21 does not apply during warfare. See Stephanie N. Simonds, Conventional Warfare and Environmental Protection: A Proposal for International Legal Reform, 29 STAN. J. INT'L L. 165, 192 (1992).

208. Stockholm Declaration, supra note 203, princ. 26.

209. See G.A. Res. 37/7, U.N. GAOR, 37th Sess., Supp. No. 51, at 21, U.N. Doc. A/RES/37/7; World Charter for Nature, U.N. Doc. A/37/L.4 \& Add.1 (1982). In the General Assembly vote, 17 nations abstained, while one, the United States, voted against the resolution. The U.S. vote was not based on the provisions concerning warfare. See 1981 U.N.Y.B. 1026.

210. In the General Assembly resolution, those principles of conservation intended to serve as "the common standard by which all human conduct affecting nature is to be guided and judged" are set forth. World Charter for Nature, supra note 209, pmbl.

211. The first four of these principles urge against disruption of the "essential processes" of nature, assert the need to safeguard habitats to prevent extinction, encourage protective regimes for unique areas, and argue for an ecosystem approach to maintenance of environmental well-being. Id. princs. 1-4.

212. Id. princ. 5 . 
avoided."213 Coming on the heels of Protocol I and ENMOD, the World Charter reflected the broadest statement on war and the environment to date by an intergovernmental organization. ${ }^{214}$

A decade after adoption of the World Charter, the United Nations sponsored the "Earth Summit" in Rio de Janeiro to commemorate the twentieth anniversary of the Stockholm Conference. At the summit, five documents were produced: the Climate Change Convention, the Declaration of Principles on Forest Conservation, the Convention on Biological Diversity, Agenda 21, and the Rio Declaration. It is the last of these that is relevant to this study.

The Rio Declaration is an effort to update the Stockholm Declaration. Of particular importance is principle 2, which revises Stockholm principle 21 by placing greater emphasis on the sovereign prerogative to develop one's own resources. ${ }^{215}$ This was done to satisfy the developing states' desire to ensure that environmental "restrictions" (the Declaration is technically nonbinding) would not hinder their growth. Unfortunately, the concession actually decreases environmental protection, for development will assume greater weight in the balancing process. Additionally, the emphasis on development highlights the Declaration's relatively anthropocentric nature. Indeed, it exemplifies the fact that evolution toward an intrinsic value approach is most likely to come in presently developed countries. After all, it is only logical that basic human needs must be satisfied before a cognitive prism other than an anthropocentric one can be internalized.

Despite this rather restrictive view, the Rio Declaration, unlike its predecessors, directly addresses the effect of warfare on the environment. In principle 24 , it characterizes warfare as "inherently destructive of sustainable development" and notes that states must, therefore, "respect international law providing protection for the environment in times of armed conflict and cooperate in its further development, as necessary."216 It is not surprising

213. Id. princ. 20.

214. As might be expected, the Charter was a predominantly anthropocentric product. This is particularly apparent in the seven principles related to "responsibilities" of parties. For instance, the section begins with the statement that "[i]n the decision-making process it shall be recognized that man's needs can be met only by ensuring the proper functioning of the natural systems." Id. princ. 6 . Similarly, in assessing whether to proceed with activities that pose a significant risk to nature, proponents are required to "demonstrate that expected benefits outweigh potential damage to nature." Id. princ. 11(b). While not purely anthropocentric (because the risk calculation need not be measured in terms of the contribution nature's damaged aspect makes to man), the mere fact that balancing occurs suggests an anthropocentric perspective.

215. Principle 2 of the Rio Declaration provides:

States have, in accordance with the Charter of the United Nations and the principles of international law, the sovereign right to exploit their own resources pursuant to their own environmental and developmental policies, and the responsibility to ensure that activities within their jurisdiction or control do not cause damage to the environment of other States or of areas beyond the limits of national jurisdiction.

Rio Declaration, supra note 114, princ. 2 (emphasis added). The next two principles cement the theme: "The right to development must be fulfilled so as to equitably meet developmental and environmental needs of present and future generations." Id. princ. 3. "In order to achieve sustainable development, environmental protection shall constitute an integral part of the development process and cannot be considered in isolation from it." Id. princ. 4.

216. Id. princ. 24 
that the Declaration included this principle, coming as it did on the heels of the Gulf War. Though an exhortation to comply with existing law is purely hortatory, and the admonition to cooperate merely aspirational, the Rio Declaration provides additional evidence that environmental damage during combat remains in the international spotlight.

Finally, the Rio Declaration handles the issue of state responsibility for environmental damage by urging further development in that area of the law. It encourages states to address liability and compensation issues through national legislation. Recognizing, however, that the problem is one of international scope that requires an international remedy, the Declaration also exhorts states to "cooperate in an expeditious and more determined manner to develop further international law regarding liability and compensation for adverse effects of environmental damage caused by their activities within their jurisdiction or control to areas beyond their jurisdiction." 217

A last document of importance among nonbinding instruments is the Draft Articles on State Responsibility of the International Law Commission (ILC) ${ }^{218}$ In article 19(3)(d), the ILC recommends that "a serious breach of an international obligation of essential importance for the safeguarding and preservation of the human environment, such as those prohibiting massive pollution of the atmosphere or of the seas," should be regarded as an international crime. ${ }^{219}$ To date, the article remains purely aspirational. Nevertheless, it is another indication that the environment per se is increasingly deemed deserving of protection. ${ }^{220}$

In terms of binding international environmental law, the most basic and widely accepted traditional principle is expressed in the maxim sic utere tuo ut alienum non laedas-use your property in such a manner so as not to injure another. This principle was the basis for the holding in Trail Smelter. ${ }^{221}$ The case involved a smelter that was discharging sulfur dioxide near the town of Trail in British Columbia. According to the United States, the sulfur dioxide drifted over parts of the state of Washington, thereby damaging commercial forests. The United States and Canada referred the case to an arbitration

217. Id. princ. 13 .

218. International Law Commission Draft Articles on State Responsibility, [1980] 2 Y.B. INT'L L. CoMm'N 26, U.N. Doc. A/35/10. In 1947 the U.N. General Assembly established the ILC for the purpose of conducting international law research and drafting conventions. Its membership includes internationally recognized scholars and practitioners of international law.

219. Id. art. 19, para. 3(d).

220. Note that this article is referring to state crimes, not individual crimes under international law. Professor Greenwood has placed this in appropriate perspective:

Whether the Commission's attempt to create a concept of State crimes separate from other breaches by states of their international obligations will prove acceptable and whether it will actually make any difference to the substantive law (as opposed to such issues as the standing to bring a claim) is debatable. What matters for present purposes is the clear recognition that a State incurs responsibility under international law for the breach of its environmental obligations.

Christopher Greenwood, State Responsibility and Civil Liability for Environmental Damage Caused by Military Operations, Paper Presented at the Symposium on the Protection of the Environment During Armed Conflict and Operations Other Than War, in NWC SYMPOSIUM PAPERS, supra note 13 (manuscript at 2, on file with The Yale Joumal of International Law).

221. Trail Smelter (U.S. v. Can.), 3 R.I.A.A. 1911 (1941). For an interesting revisionist view of the case, see Karin Mickelson, Rereading Trail Smelter, 31 CAN. Y.B. INT'L L. 219 (1993). 
tribunal, which held for the United States on the grounds that countries have a duty not to use, or allow the use of, their territory for activities harmful to another state. ${ }^{222}$ Since then, the principle has been reiterated in international agreements and domestic tribunals. ${ }^{223}$ Drawing on tort law, the arbitration award emphasized that the plaintiff has to show both material damage and causation. Purely speculative damage is not actionable. ${ }^{224}$

Little additional case law specifically addresses environmental damage. Two interesting cases that might have moved the law forward, had they been decided on the merits, are the Nuclear Test Cases. ${ }^{225}$ Resorting to the ICJ, New Zealand and Australia charged that French atmospheric nuclear testing in the South Pacific harmed them. The case was never heard on the merits because France voluntarily ceased testing. When it did so, the ICJ dismissed the case as moot. ${ }^{226}$ Interestingly, prior to the French agreement to halt the tests, the court issued interim relief that directed France to stop testing. ${ }^{227}$ While this might be characterized as suggesting sympathy for Australia and New Zealand's position, a better reading is that it was merely standard injunctive relief designed to foreclose the possibility of irreparable harm.

General acceptance of the Trail Smelter principle was signaled most clearly when the American Law Institute included a section addressing the concept in its Restatement (Third) of Foreign Relations Law of the United

222. See Trail Smelter, 3 R.I.A.A. at 1965.The arbitral tribunal stated:

[U]nder the principles of international law, as well as of the law of the United States, no State has the right to use or permit the use of its territory in such a manner as to cause injury by fumes in or to the territory of another or the properties or persons therein, when the case is of serious consequence and the injury is established by clear and convincing evidence.

Id. Interestingly, in addition to international law, the arbitral tribunal looked to domestic law, including such U.S. Supreme Court cases as Missouri v. Illinois, 200 U.S. 496 (1906) (water pollution) and Georgia v. Tennessee Copper Co., 206 U.S. 230 (1907) (air pollution). See Trail Smelter, 3 R.I.A.A. at 1964-65.

223. See, e.g., LOS Convention, supra note 172, art. 194, para. 2 ("States shall take all measures necessary to ensure that activities under their jurisdiction or control are so conducted as not to cause damage by pollution to other States and their environment, and that pollution arising from incidents or activities under their jurisdiction or control does not spread beyond the areas where they exercise sovereign rights . . . ."); see also Convention on Long-Range Transboundary Air Pollution, Nov. 13, 1979, pmbl., 18 I.L.M. 1442 [hereinafter Air Pollution Convention]. For examples of national cases, see Antoine, supra note 51, at 519 n.4 (citing cases decided in Strasbourg and Rotterdam).

224. Though no other international cases involve environmental damage as a core issue, others bear more generally upon uses of a state's territory that cause damage beyond its borders. See, e.g., Corfu Channel (U.K. v. Alb.), 1949 I.C.J. 4 (Apr. 9). Corfu Channel involved two British warships that were damaged in 1946 when the vessels hit German mines in Albanian waters in the Straits of Corfu. Several sailors were killed. On the issue of state responsibility, the ICJ ruled in the United Kingdom's favor, finding that Albania must have known of the mines' presence, and did nothing to warn the ships despite its duty to do so. As it bears on the environment, Corfu Channel stands for the principle that a state is obligated to refrain from allowing its territory to be used in a fashion that causes harm to others. See id. at 22; see also Lake Lanoux Arbitration (Fr. v. Spain), 12 R.I.A.A. 281 (1957) (holding that although Spain cannot preclude France from using upstream water as it sees fit, as matter of equity, France should consider Spain's counterproposals for use).

225. Nuclear Tests (Austl. v. Fr.), 1974 I.C.J. 253 (Dec. 20); Nuclear Tests (N.Z. v. Fr.), 1974 I.C.J. 457 (Dec. 20).

226. See Nuclear Tests (Austl. v. Fr.), 1974 I.C.J. at 271-72; Nuclear Tests (N.Z. v. Fr.), 1974 I.C.J. at $477-78$.

227. See Nuclear Tests (Austl. v. Fr.), 1973 I.C.J. 99 (Interim Protection Order of June 22); Nuclear Tests (N.Z. v. Fr.), 1973 I.C.J. 135 (Interim Protection Order of June 22). 
States. ${ }^{228}$ Since it succinctly sets forth not only the substantive law, but also the concept of state responsibility, it merits quotation in full:

(1) A state is obligated to take such measures as may be necessary, to the extent practicable under the circumstances, to ensure that activities within its jurisdiction or control

(a) conform to generally accepted international rules and standards for the prevention, reduction and control of injury to the environment of another state or of areas beyond the limits of national jurisdiction; and

(b) are conducted so as not to cause significant injury to the environment of another state or of areas beyond the limits of national jurisdiction.

(2) A state is responsible to all other states

(a) for any violation of its obligations under Subsection (1)(a), and

(b) for any significant injury, resulting from such violation, to the environment of areas beyond the limit of national jurisdiction or control.

(3) A state is responsible for any significant injury, resulting from a violation of its obligations under Subsection (1), to the environment of another or to its property, or to persons or property within that state's territory or under its jurisdiction or control. ${ }^{229}$

Would this principle apply in times of armed conflict? That would depend on the context. The principle is less about the environment than about state responsibility for the use of its territory. In Trail Smelter, for example, the importance of the environmental element is subsumed in the broader principle imposing an obligation to protect other states from injurious acts emanating from within one's own borders. Characterized this way, it would be illogical for such a principle to apply between belligerents, for the use of one's territory to damage an enemy is the essence of warfare.

But what about harm caused to nonbelligerents? There is nothing necessarily inconsistent between an obligation to avoid causing harm to the territory of a nonbelligerent and engaging in hostilities with a third state. Nevertheless, this is a more complex question. The most basic principle of neutrality law is that the territory of neutral powers is generally inviolable. ${ }^{230}$ Would the passage of pollutants into a nonbelligerent's territory constitute a violation of territorial integrity? It might not; Canada's breach in Trail Smelter was that it caused damage from within its territory, not that substances originated there and passed into the United States. The key is effect, not movement. Furthermore, the neutrality principle was traditionally based on physical intrusions, usually by military assets of the belligerents. ${ }^{231}$

A better approach is to recognize that neutrality law is premised on the need to balance the rights of neutrals and those of belligerents during armed

228. RESTATEMENT (THIRD) OF FOREIGN RELATIONS LAW OF THE UNITED STATES $\$ 601$ (1987) [hereinafter RESTATEMENT (THIRD)].

229. Id. Professor Walker has argued that the Restatement may not be very helpful when law of armed conflict issues interact with the law of the sea and environmental law. See Walker, supra note 52, at 192.

230. See Convention Respecting the Rights and Duties of Neutral Powers and Persons in Case of War on Land, Oct. 18, 1907, art. 1, 36 Stat. 2310; see also AFM 27-10, supra note 175, ch. 9 (land warfare); Convention Concerning the Rights and Duties of Neutral Powers in Naval War, Oct. 18, 1907, 36 Stat. 2415.

231. On the purposes underlying the law of neutrality, see Patrick M. Norton, Between Ideology and the Reality: The Shadow of the Law of Neutrality, 17 HARV. INT'L L.J. 249 (1976); Walter L. Williams, Neutrality in Modern Armed Conflicts: A Survey of the Developing Law, 90 MiL. L. REV. 9 (1980). 
conflict. In other words, Trail Smelter should stand for the premise that causing, or allowing to be caused, environmental damage in another country can lead to state responsibility unless belligerent interests served by the action in question outweigh the victim state's interests in avoiding the damage. Relevant factors would include (a) the magnitude of harm caused and (b) the nature of the threat to the "breaching" state that necessitated the harmful actions. ${ }^{232}$ This mode of analysis is not unprecedented in international law. Blockade law, for instance, emerged from a need to balance belligerents' interests in effective warfare with neutrals' interests in international commerce. ${ }^{233}$ It would be reasonable to conduct an analogous balancing test here. In much the same way that an interest in international commerce arose in the nineteenth century, an interest in being free from environmental damage has surfaced in the latter half of the twentieth century. It is therefore appropriate that sovereignty interests in the use of one's territory, and in effectively conducting combat operations, yield to some extent in the face of growing international concern over the environment.

Environmental treaty law is much narrower than the general principles discussed above, in that it tends to focus on a single component of the environment. In fact, the only rules that are designed to protect the environment in general appear in nonbinding instruments. Of the multitude of environmental provisions scattered throughout international conventions, and the many international, regional, and bilateral agreements addressing specific issues, three have been selected for sake of illustration: the Law of the Sea (LOS) Convention, ${ }^{234}$ the Convention for the Protection of the Ozone Layer, ${ }^{235}$ and the Convention on Long-Range Transboundary Air Pollution. ${ }^{236}$ As mentioned earlier, the essential task when considering the issue of peacetime environmental prescriptions is not to catalogue them, since they constitute a body of law that is constantly evolving, but rather to understand when peacetime instruments and legal principles apply in armed conflict.

The LOS Convention is the first global attempt to limit marine pollution in any comprehensive way. ${ }^{237}$ This 1982 instrument, which entered into force in 1994, requires states to take whatever measures are necessary "to prevent, reduce and control pollution of the marine environment from any

232. The remedy for a breach is set forth in section $602(1)$ of the Third Restatement: "A state responsible to another state for violation of section 601 is subject to general interstate remedies to prevent, reduce or terminate the activity threatening or causing the violation, and to pay reparations for the injury caused." RESTATEMENT (THIRD), supra note 228, § 602(1).

233. See Michael N. Schmitt, Aerial Blockades in Historical, Legal and Practical Perspective, 2

U.S.A.F.A. J. LEGAL STUD. 21, 24-33 (1991).

234. LOS Convention, supra note 172.

235. Ozone Convention, supra note 206.

236. Air Pollution Convention, supra note 223.

237. See LOS Convention, supra note 172. One of its precursors, the 1958 Convention on the High Seas, addressed marine pollution in only two provisions. Article 24 required state regulation of marine pollution by oil discharges from vessels, pipelines, or deep seabed activities, and article 25 called upon parties to prevent pollution of the seas from radioactive materials. See Convention on the High Seas, Apr. 29, 1958, arts. 24-25, 13 U.S.T. 2312, 450 U.N.T.S. 82. The nonbinding Stockholm Declaration exhorted states to take "all possible steps" to prevent marine pollution. Stockholm Declaration, supra note 203, princ. 7 . 
source, using for this purpose the best practicable means at their disposal." 238 It also restates the general principle that states must ensure that activities over which they exercise control or jurisdiction do not cause damage to other states or the environments thereof. ${ }^{239}$ Interestingly, this standard does not contain the Third Restatement's qualifier that only "significant" damage will trigger the protections.

While these statements appear broad, the LOS Convention excludes vessels owned or operated in noncommercial service by a government, including warships, from compliance with its marine protection principles. ${ }^{240}$ Does this mean that the Convention is devoid of environmental provisions that might offer protection in wartime? ${ }^{241}$ It does not, because a state might cause the spill of pollutants (e.g., oil) from vessels that are not exempted, as the Iraqis did when they began releasing oil from commercial tankers during the Gulf War. ${ }^{242}$ More importantly, the agreement encompasses activities other than releases from vessels. For instance, the Convention's general principles specifically apply to minimizing the release of "toxic, harmful or noxious substances, especially those which are persistent, from land-based sources." ${ }^{243}$ The release of oil from shore-based facilities during the Gulf War immediately comes to mind. The principles also extend to "installations and devices operating in the marine environment"244 other than vessels, such as offshore oil platforms. Additionally, parties are obligated to adopt, through domestic legislation and in cooperation with international organizations, laws and measures to preclude marine pollution originating from shore-based or seabed activities, as well as from or through the atmosphere. ${ }^{245}$

The problem with these prescriptions is their inherent imprecision. By

238. LOS Convention, supra note 172, art. 194, para. 1. The LOS Convention defines pollution of the marine environment as

the introduction by man, directly or indirectly, of substances or energy into the marine environment, including estuaries, which results or is likely to result in such deleterious effects as harm to living resources and marine life, hazards to human health, hindrance to marine activities, including fishing and other legitimate uses of the sea, impairment of quality for use of sea water and reduction of amenities.

Id. art. 1, para. 1(4).

239. See id. art. 194, para. 2 ("[s]tates shall take all measures necessary to ensure that activities under their jurisdiction or control are so conducted as not to cause damage by pollution to other states and their environment.").

240. See id. art. 236 ("The provisions of this Convention regarding the protection and preservation of the marine environment do not apply to any warship, naval auxiliary, other vessels or aircraft owned or operated by a State and used, for the time being, only on government non-commercial service.").

241. Though not on point at this juncture, the Convention contains two provisions relevant to the issue of the jus ad bellum. In article 88 , it provides that "[t]he high seas shall be reserved for peaceful purposes," whereas in article 301 it states that

[i]n exercising their rights and performing their duties under this Convention, States Parties shall refrain from any threat or use of force against the territorial integrity or political independence of any State, or in any other manner inconsistent with the principles of international law embodied in the Charter of the United Nations.

Id. art. 301. Of course, neither article would preclude a state's exercise of appropriate collective or individual self-defense under article 51 of the U.N. Charter.

242. Iraq ratified the LOS Convention in 1985.

243. LOS Convention, supra note 172 , art. 194, para. 3(a).

244. Id. art. 194, para. 3(d).

245. See id. arts. 207-08, 212. 
what standard, for example, should a state's cooperation with international organizations be measured? What steps satisfy the requirement to "minimize" releases? What does the phrase "necessary measures" encompass? There is little question that the LOS Convention will be difficult to apply in practice. That said, law is seldom precise, nor should it always be. It has to be flexible enough to fit a multiplicity of situations-many unforeseen when the law emerges. Moreover, the concerns expressed here are primarily about negligent or reckless conduct; intentional conduct, such as Iraqi conduct during the Gulf War, would be less susceptible to interpretive variation under the Convention. As with all peacetime law, though, applicability of the LOS Convention would have to be tested against the contextual standards suggested during the discussion of the theory of differentiation.

The Convention's enforcement regime is unique in approach. With reference to pollution, it places authority, depending on the specific circumstances, in the hands of the flag, port, or coastal state. Furthermore, it provides for an International Tribunal for the Law of the Sea to resolve Convention-based disputes. At the time of signing, ratifying, or acceding to the Convention, parties are required to accept the jurisdiction of this body (currently being established) or of the International Court of Justice, or to agree to submit disputes to arbitral proceedings. By peacetime enforcement standards, this is a particularly robust system for remedying alleged wrongs.

A second sample treaty with potential prescriptive effect during armed conflict is the 1985 Vienna Convention for the Protection of the Ozone Layer (the Ozone Convention). ${ }^{246}$ Its normative component is article $2(1)$, by which parties agree to "take appropriate measures in accordance with the provisions of [the] Convention and of [related protocols] to protect human health and the environment against adverse effects resulting or likely to result from human activities which modify or are likely to modify the ozone layer."247 Beyond this, the agreement essentially is designed to foster the exchange of information on potential ozone layer damage. As to enforceability, the Convention has few teeth. It provides for dispute settlement through negotiation or mediation, and encourages parties to agree in advance to the compulsory jurisdiction of the ICJ or to binding arbitration. ${ }^{248}$

The third sample peacetime agreement is the Convention on Long-Range Transboundary Air Pollution of $1979 .{ }^{249}$ In this agreement, party states express their determination to "protect man and his environment against air pollution and ... . endeavour to limit and, as far as possible, gradually reduce and prevent air pollution including long-range transboundary air pollution." 250 In the Convention, transboundary air pollution is defined as pollution originating in one state and causing harm in another, but in which

246. Ozone Convention, supra note 206.

247. Id. art. 2, para. 1. Adverse effects are defined as "changes in the physical environment or biota, including changes in climate, which have significant deleterious effects on human health or on the composition, resilience and productivity of natural and managed ecosystems, or on materials useful to mankind." Id. art. 1, para. 2.

248. See id. art. 11.

249. Air Pollution Convention, supra note 223.

250. Id. art. 12. 
the relative contribution from individual sources cannot be determined..$^{251}$ This is an attempt to escape from the classic tort problems of determining causation and harm. In this sense, it certainly represents a step beyond the principle of responsibility expressed in Trail Smelter. On the other hand, though the ambit of responsibility is stretched beyond the traditional levels, the standard of responsibility is de minimis. Note the terminology_"endeavour," "as far as possible," and "gradually." It would be difficult to craft a more aspirational norm. To compound matters, the Convention does not impose conditions of responsibility or liability; rather, it encourages "negotiation" or resort to other "method[s] of dispute settlement acceptable to the parties to the dispute." 252

After a review of the state of peacetime environmental law and its applicability during armed conflict, it should be apparent that reports of its death during armed conflict are greatly exaggerated. Nevertheless, much uncertainty plagues the topic. The most reasonable approach is one in which a treaty's survival during armed conflict depends on a contextual evaluation employing factors such as those suggested above. As to the Trail Smelter principle, applicability during hostilities optimally should depend on a balancing of the interests of belligerents and nonbelligerents.

The substantive law presents less of an analytical problem because, at least to date, it offers little normative guidance of direct relevance to warfare beyond the hortatory and aspirational. Peacetime law was not intended to respond to the intent to create environmental destruction or to use the environment as a weapon. What is contemplated, then, is extension of a law designed primarily for reckless, negligent, or intentional acts motivated by a purpose other than harm. This is reflected in the limited remedies available to injured parties. Also apparent is an inherent tension between developing and developed states over how to balance the requirements of development with the desire to protect the environment. Application of peacetime environmental law during armed conflict will be limited by competing interests, much as the Trail Smelter principle was limited by belligerents' interests in effective warfighting. The result is that, despite some useful provisions (and even if consensus could be reached on its applicability), peacetime environmental law contributes little to wartime environmental protection.

Finally, mention should be made of legal responsibility, a topic applicable to both war and peace. ${ }^{253}$ Whereas the law of armed conflict provides for individual responsibility (e.g., war crimes), peacetime instruments generally do not. For instance, the Third Restatement provisions do not mention the possibility that wrongful environmental damage might rise to the level of an international crime. Therefore, to the extent that peacetime prescriptions are carried forward into armed conflict, they alone do not form the basis for

251. See id. art. 1.

252. Id. art. 13.

253. An in-depth analysis is beyond the scope of this Article. For two excellent studies of the topic, see L.C. Green, State Responsibility and Civil Reparation for Environmental Damage, Paper Presented at the Symposium on the Protection of the Environment During Armed Conflict and Operations Other Than War, in NWC SYMPOSIUM PAPERS, supra note 13; Greenwood, supra note 220. 
criminal responsibility.

Nevertheless, there is little question about state responsibility. If peacetime prescriptions remain in effect, the associated remedial provisions must logically do so as well. The principle that states are responsible for the wrongful acts of their agents-officials, armed forces, etc.-supports this premise. ${ }^{254}$ Yet, some practical and legal uncertainty remains. How does one assess responsibility in multilateral operations? Should liability be joint and several? How does one measure harm, recalling, for instance, the imprecision of initial estimates in the Gulf War? How does one handle potential harm that may not become obvious for years after an event? Who has standing to assert claims for damage caused to the global commons? Are the relevant obligations erga omnes, such that they can be enforced by any state? ${ }^{255}$ How should the two peacetime principles that relieve a state of responsibility-distress and necessity-apply in a wartime context? ${ }^{256}$ These and other gaps remain in this essential component of the legal regime designed to deter environmental destruction.

\section{B. Customary Jus in Bello}

Custom is at the core of the jus in bello. Indeed, as a source of the law of war it predates any of the applicable treaty law currently in force. ${ }^{257}$ To achieve the status of customary law, a norm must be evident in widespread state practice over time and the international community has to exhibit opinio juris sive necessitatis, a conviction that the rule is obligatory. ${ }^{258}$ In other

254. Numerous law of war treaties provide for such responsibility. See, e.g., Hague IV, supra note 130, art. 3 ("A belligerent party which violates the provisions of the said Regulations shall, if the case demands, be liable to pay compensation. It shall be responsible for all acts committed by persons forming part of its armed forces."). A nearly identical provision is found in Protocol I, supra note 8, art. 91.

255. The concept of erga omnes appears in the Barcelona Traction Case. There, the ICJ held that an essential distinction should be drawn between the obligations of a State towards the international community as a whole, and those arising vis-à-vis another State. . . . By their very nature the former are the concern of all States. In view of the importance of the rights involved, all States can be held to have a legal interest in their protection; they are obligations erga omnes. Such obligations derive, for example, in the contemporary international law, from outlawing acts of aggression, and of genocide, as also from the principles and rules concerning the basic rights of the human person, including protection from slavery and racial discrimination.

Barcelona Traction, Light \& Power Co. (2d Phase) (Belg. v. Spain), 1970 I.C.J. 3, 32 (Feb. 5). The court did not indicate how obligations erga omnes were to be enforced.

256. See International Law Commission Draft Articles on State Responsibility, supra note 218, arts. 32-33; see also Leibler, supra note 185 , at 76-77.

257. That custom can form the basis for war crimes charges was acknowledged by the International Military Tribunal at Nuremberg. The indictment specifically noted that "[a]ll the defendants committed War Crimes ... . [pursuant to] a Common Plan or Conspiracy . . . . This plan involved . . the practice of 'total war' including methods of combat and of military occupation in direct conflict with the laws and customs of war." Indictment, International Military Tribunal, Nuremberg, 1 T.M.W.C. 27, 42-43 (1947) (emphasis added). Today, this premise is accepted as a principle of customary international law.

258. The Statute of the International Court of Justice provides that the court shall apply custom as "evidence of a general practice accepted as law." STATUTE OF THE INTERNATIONAL COURT OF JUSTICE, June 26, 1977, art. 38, para. 1(b). The Third Restatement notes that custom "results from a general and consistent practice of states followed by them from a sense of legal obligation." RESTATEMENT (THIRD), supra note 228, § 102(2); see also The Paquete Habana, 175 U.S. 677 (1900); Right of Passage Over Indian Territory (Port. v. India), 1960 I.C.J. 6 (Apr. 12); Asylum (Colom. v. Peru), 1950 I.C.J. 266 
words, custom is both a behavioral and a perceptional entity.

The foundational customary principle of the law of war, codified in Hague IV and elsewhere, is that the right of belligerents to adopt means of injuring the enemy is not unlimited. ${ }^{259}$ From this principle flow a number of subsidiary principles that underlie much of the remainder of the law of war, whether found in custom or treaties. ${ }^{260}$ They are perhaps best understood as grouped into four broad categories: military necessity, proportionality, humanity, and chivalry. Chivalry, which involves such matters as perfidy and ruses, is of only peripheral relevance to this study and will not be discussed.

\section{Military Necessity}

Military necessity prohibits destructive or harmful acts that are unnecessary to secure a military advantage. It is well settled that a violation of the principle can constitute a war crime. Article $6(\mathrm{~b})$ of the Charter of the International Military Tribunal specifically characterizes "the wanton destruction of cities, towns or villages or devastation not justified by military necessity" as a war crime. ${ }^{261}$ The offense is further clarified in a frequently cited passage from a well known war crimes trial, The Hostage Case:

[Military necessity] does not permit the killing of innocent inhabitants for purposes of revenge or the satisfaction of a lust to kill. The destruction of property to be lawful must be imperatively demanded by the necessities of war. Destruction as an end in itself is a violation of international law. There must be some reasonable connection between the destruction of property and the overcoming of the enemy forces. ${ }^{262}$

By this standard, an actor must be able to articulate the imperative military advantage intended to be gained. In other words, the act must be neither wanton nor of marginal military value, and military motivations must underlie it.

There are three basic challenges in applying the principle of military necessity to environmental damage. First, the standard invites interpretive variance. Most importantly, what do the phrases "imperatively demanded" and "reasonably connected" mean? In other words, how "direct" must an advantage be before an act becomes militarily necessary? A subjective concept, directness can be placed along a continuum, and at some point a

(Nov. 20); S.S. Lotus (Fr. v. Turk.), 1927 P.C.I.J. (ser. A) No. 10 (Sept. 7).

259. See, e.g., Hague IV, supra note 130, art. 22; Protocol I, supra note 8, art. 35, para. 1. The principle was first recognized in the Declaration of St. Petersburg, 1868, reprinted in $1 \mathrm{AM}$. J. INT'L L. 95 (Supp. 1907).

260. Unfortunately, though the substance of these principles is subject to little debate, the form in which they are expressed varies. For instance, the Air Force employs the categories of military necessity, humanity, and chivalry, with proportionality folded into necessity, whereas the Navy uses necessity, proportionality and chivalry. Compare AFP 110-31, supra note 175, at 1-5 to 1-6, with NWP 1-14M, supra note 178 , at $5-1$. In substance and application, though, the principles are identical across the military services.

261. Agreement for the Prosecution and Punishment of the Major War Criminals of the European Axis Powers and Charter of the International Military Tribunal, Aug. 8, 1945, art. 6(b), 59 Stat. 1544, 82 U.N.T.S. 279.

262. Hostage (U.S. v. List), 11 T.W.C. 759, 1253-54 (1950). 
"direct" advantage becomes "remote" in nature. The question is where.

The fact that the delineation point is contextually determined renders it difficult to identify. All would agree, for example, that it generally would be permissible to set fire to a field through which a superior enemy force is advancing in order to halt the advance or mask one's own retreat. The advantage is direct and military in nature. But would it be permissible to set fire to the field in order to demoralize the rural population and turn it against continuation of the war? Clearly not. The advantage is military only in a convoluted sense and is obviously remote. In legal terms, the chain of causation is too attenuated. This is an easy case. The tough ones lie in the middle. Using a Gulf War example, did setting oil wells on fire to obscure Coalition targeting offer a direct military advantage? If it did, at what point had enough wells been set ablaze to suffice, so that igniting further wells was "wanton"? The contextual character of military necessity was equally apparent in the post-World War II war crimes trials, in which scorched-earth policies were held to be acceptable when motivated by military need in exceptional circumstances, but were condemned when the resulting destruction was found to be wanton. ${ }^{263}$ Thus the difficulty in understanding whether an act is militarily necessary is compounded by the fact that it cannot be assessed in the abstract. Only in extreme cases will violation of the principle be apparent on the face of the action.

A related definitional problem lies in discerning requisite likelihood. Return again to the Gulf War. If the Iraqi oil spill was in fact intended to foil amphibious landings (and did not violate any other legal prescriptions), how likely must those landings have been before the advantage sought was direct? Is there a point at which the low likelihood of occurrence renders an advantage remote? There must be, for surely no one would argue that military necessity is consistent with destructive measures taken to counter any theoretical threat. To shift direction slightly, how does the likelihood of success figure in? A tactic or operation may very well entail an obvious chain of causation, and the threat posed may have a high likelihood of occurrence, but what degree of certainty of success is required to reach the "direct" advantage threshold? Unless one is willing to conclude that the principle of military necessity is intended to prevent only wanton (as opposed to wildly speculative) acts, the likelihood of occurrence and success must be directly relevant to military necessity calculations.

This latter point leads to the second challenge in determining military necessity, that of ascertaining intent. The essence of the principle is a prohibition on wanton, or largely irrelevant, destruction. Wantonness, in turn, implies the absence of intent to secure a military advantage. Thus, though formal statements of the principle, found in such sources as law of war manuals, often do not include an intent element, in practice one must be read into the prescription. The Gulf War illustrated this point. For instance, the

263. See InTERnational COMm. OF tHE RED Cross, Commentary: Geneva Convention Relative to the Protection of Civilian Persons in Time of WaR 302 (Jean S. Pictet ed., 1958) [hereinafter Pictet]. The set of four ICRC Commentaries edited by Jean Pictet is the definitive source on interpretation of the Geneva Conventions of 1949. 
DOD Report asserted that had Iraq's goal been to obscure target acquisition by Coalition pilots, it could simply have opened the valves and ignited the oil that spilled. Therefore, the destruction of the oil wells themselves was taken as an indication of Iraq's "punitive" intentions. ${ }^{264}$ But had the intent not been punitive, the requirements of military necessity would probably have been met. Therein lies the quandary. Given that intent is relevant, how is it to be determined in cases in which the act in question is reasonably subject to differing interpretations?

Acknowledging such interpretative and applicative difficulties hardly represents a jurisprudential epiphany on the subject of military necessity. The question, however, is whether environmental issues will exacerbate these difficulties. Unfortunately, they will, at least until warfighters, military lawyers, and scientists better understand the relationship between the art and science of warfare and the environment. Consider a few theoretical operational possibilities. How might a commander fold the ability to control weather into an offensive air operation? Of what use could obscurants be in defending against airborne assaults? How might flooding be used to protect a flank in an armored advance? These and other issues are only beginning to be explored.

To some extent, most emergent technologies or techniques present this type of dilemma. The more difficult it is to articulate a concept of employment, the harder it will be to justify an action as being of direct military advantage. Paradoxically, this difficulty also will hinder unambiguous characterization of a novel practice as a violation of the military necessity principle. To complicate matters further, the less established the technique or tactic in military practice, the more difficult it will be to impute intent to the actor. Lastly, necessity is harder to calculate because novelty generally lowers the reliability of estimates of the probability of success.

A final criticism of the principle is that it operates at cross purposes with the aims of the law of armed conflict, particularly its environmental component. As one commentator has noted, " $[t]$ he dictates of military necessity, as assessed by opposed leaderships, have taken consistent precedence over the laws of war in almost every critical aspect of belligerent policy." 265 While it is true that commanders and their judge advocates occasionally may argue that military necessity justifies an action, such assertions are really about proportionality, not about necessity. After all, the statement implies that a balancing has occurred. Military necessity, in contrast, is less akin to balancing than it is to placement along a continuum. Thus, the criticism wrongly characterizes the assertion of the relevance of "necessity" analysis.

Much more importantly, the criticism seems to turn military necessity on its head. Recall the international law maxim that what is not forbidden is permitted. Military necessity operates within this paradigm to prohibit acts that are not militarily necessary; it is a principle of limitation, not authorization. In its legal sense, military necessity justifies nothing. The

264. DOD REPORT, supra note 69 , at 0-27.

265. RICHARD FALK, REVITALIZING INTERNATIONAL LAW 168 (1989). 
criticism also mischaracterizes military necessity as in opposition to the law of war, when it is, in fact, an integral part of that corpus of law. The criticism would be more appropriately directed to the principle of war labeled "objective," rather than to a principle of law. It makes little sense to suggest that the legal principle of necessity runs counter to the law of war itself.

The discussion of challenges presented by the principle of military necessity is not meant to suggest that necessity is becoming passé vis-à-vis environmental issues. Instead, the point is merely that before accepting the premise that existing law is adequate, we must understand how much more complex the task of judging military necessity is made by factoring in environmental considerations. ${ }^{266}$

\section{Proportionality}

The difficulties in assessing military necessity pale beside those surrounding proportionality. Proportionality is a concept complementary to, and often considered a component of, military necessity. ${ }^{267}$ It is perhaps best characterized as the principle of customary international law that prohibits injury or damage disproportionate to the military advantage sought by an

action. Measured not in terms of immediate advantage, but rather with regard to the operation as a whole, the concept extends both to collateral damage suffered by civilians and civilian objects and to destruction of otherwise legitimate targets. ${ }^{268}$

Being relative, proportionality can be placed along a continuum. At some point on that continuum a proportionate impact becomes disproportionate, and the balance shifts. Because dissimilar value systems-military and humanitarian-are being compared, this point is very difficult to locate. For example, if the target is a command post near a residential area, how many surrounding homes may be destroyed before the effort to disable it becomes disproportionate? Similarly, what is the value of an enemy aircraft in terms of human lives? How do you compare the suffering caused by the destruction of joint civilian-military facilities, such as electrical generating facilities, with the military utility of disrupting the enemy's command and control? ${ }^{269}$

266. The difficulty in applying the concept was recognized in the Greenpeace Study, as was the imprecision of definition:

It is in the interpretation of military action, and specifically the concept of "military necessity"

(the anticipated military value of one's own action), that there is significant international disagreement as to proper conduct during war. Military necessity is not defined anywhere in the laws of war, but it is intertwined with proportionality and discrimination, the central principles of the "just war" tradition. GREENPEACE STUDY, supra note 69, at 115.

267. The concept often is confused with a principle of war, economy of force. Economy of force is a common sense warfighter's rule of thumb: It does not make sense to apply more force than is necessary to attain the objective. The legal concept of proportionality, in contrast, measures advantage against damage caused.

268. Generaliy, though, proportionality regarding legitimate targets is more easily dealt with as a military necessity issue.

269. For a discussion of proportionality in the context of attacks on electrical targets, see WILLIAM ARKIN, TARGET IRAQ: A DOCUMENTARY HISTORY OF THE AIR WAR (forthcoming 199) (manuscript at ch. 9, on file with author). Mr. Arkin, a human rights activist who specializes in military affairs, puts an 
The difficulty of making proportionality calculations has been a key impetus towards codification of the law of war. In theory, codification renders legal concepts more manageable. It also eases the task of disseminating them to those charged with deciding on and executing courses of action. Unfortunately, despite the growing body of codified law of war, in many cases no particular provision exists on point to facilitate a specific proportionality calculation. Faced with this predicament, warfighters sometimes are instructed to use "no more force than necessary" to achieve their objective. However, economy of force is a principle of war, not a valid legal prescription under the law of war. In fact, there are situations in which the application of minimum necessary force against an otherwise lawful target would produce disproportionate results. Therefore, absent a specific provision in treaty law, we are left to our own value systems for guidance (or, perhaps more accurately, the value system deemed authoritative by the international community). Is the law, therefore, nothing more than an articulation of that fighter pilot adage to "trust your gut"? Or is it imbued with a meaning more distinct and developed, perhaps in the sense of the Martens Clause's dictates of public conscience?

Whatever the answer, any value-based balancing test will have disturbing implications for legal predictability and consistency. Value is a cultural and contextual concept: Different societies may value life, suffering, or objects differently. The play of this contextuality grows exponentially when considering the environment. If it is difficult to agree on proportionality when human life is in the balance, how can we hope to achieve consensus on the import of destroying habitats, harming air quality, or disturbing food chains? The quandary is that proportionality requires the act of value balancing, but the very subjectivity of value renders agreement on specific balances highly elusive. Just imagine, for example, the difference between the values that the United States and a failing state might impute to the environment.

Not only do disparate value paradigms impede objective proportionality estimations, but even within our own society the debate over anthropocentric and intrinsic value is an inevitable source of contention. All reasonable people would agree that the value of the environment should be measured, at least in part, by its direct impact on the state of human existence. Some would go further and argue that the environment should be valued in and of itself, even in the absence of a specific benefit to humankind. In other words, the actual value of the environment is its anthropocentric value plus its intrinsic value. This is the moderate intrinsic value approach. Others would take the intrinsic value perspective to its extreme by asserting that the environment merits protection even at human expense. In this radical cognitive perspective, human and environmental values are distinguishable-and equivalent-in the abstract. The more moderate intrinsic value approach would urge recognition of the autonomy of environmental value, but, all things being "equal," subordinate it to human values if forced to choose between the two.

The dilemma is that each approach will yield a different value for the environmental loss that military action causes. For instance, the first evaluator 
will see in a forest a useful source of raw materials. The second will acknowledge that quality, but also will characterize the forest as an entity demanding respect in its own right. For the third evaluator, securing respect for the forest may even require sacrificing human values. Nevertheless, in each of these cases the military advantage obtained by damaging the forest is fixed. This simple example shows that the operation of the proportionality equation will be skewed not only by the subjectivity of value estimates, but also, and perhaps more importantly, by disagreement over how and on what basis to measure value in the first place.

The tension between anthropocentric and intrinsic valuations is evident at the state level as well-a point illustrated at the Rio Conference by the developing states' insistence that environmental protections be balanced by the needs of development. Assuming this represents a trend, does it portend a developed/developing state split in attitude towards the appropriateness of the various cognitive perspectives? Perhaps the best way to characterize the situation is to suggest that while the cognitive direction is very roughly constant across the international community (no one seems to be moving in the other direction), the velocity of the phenomenon is much greater in developed states. This is logical, for there is less economic friction in the developed world. If the assessment is accurate, the cognitive gap between the camps will grow, at least until the economic gulf between developed and developing states narrows. The gap will pose the same obstacles to predictable and uniform application of the proportionality principle as differing crosscultural valuation does.

This in turn raises another point regarding valuation in the proportionality calculation process: Value can be temporally determined. 270 Valuation paradigms inevitably change as history evolves, a fact aptly demonstrated by the rise of environmental consciousness in the last half-century. As this occurs, proportionality calculations shift accordingly. For example, reflect on the assessment that would be made of the Huayuankow Dam incident if it were to occur today. One scholar has suggested that this temporal feature of proportionality, and of customary law generally, is actually beneficial, for it permits the development of law to parallel the development of societal values, avoiding the difficulties inherent in applying treaty law to novel situations. ${ }^{271}$

The phenomenon of evolving value systems has many potential causes: human experience, understanding of the environment, and even technology. Of particular interest among law of war scholars and practitioners is the enormous attention that has been paid to the use of "smart" weapons during the Gulf War. To the extent that it may be technologically possible to limit collateral damage even further, there will inevitably be a tendency to ratchet

270. See Bothe, supra note 191 , at 56 .

271. As Wil Verwey has written:

Subjecting principles of customary law to a modern, liberal interpretation, i.e. a time-related interpretation which takes account of changing and emerging values cherished by society, may be less objectionable than it would be in the case of treaty law. In the former case, state parties cannot claim so easily that they have accepted a precise obligation as formulated in text, and that "that's it."

Verwey, Additional Rules, supra note 13, at 8-9. 
down the acceptable level of collateral damage, environmental or otherwise.

While the effect of new technologies may be reflected primarily in necessity analysis, there is still a subtle impact on the proportionality decision processes. Though there objectively may be no shift in the value of the damaged environment (anthropocentric or intrinsic), a subjective revaluation is bound to occur once a perception that the damage can be avoided takes hold. This is because valuations are in part the product of emotions, and we are more emotional about entities damaged "unnecessarily." Once decision makers are sensitized, proportionality calculations will be affected even when the necessity threshold has been met. Albeit not in the context of new technology, the Gulf War environmental experience offers a telling example of how this sensitization can work over time to alter existing valuation paradigms. When the Iraqis began spilling oil into the Persian Gulf and setting fire to well heads, actions that many felt were clearly unnecessary, the international community was enraged and became sensitized to the issue. As a result, operations posing environmental risks in the next war are likely to be evaluated very closely before being approved as proportional. What is interesting is that this is so despite the fact that, objectively, the environment is no more valuable than it was six years ago. On the contrary, since predictions of what Gulf War damage would do to the environment were themselves exaggerated, environmental concerns actually should have diminished somewhat. Yet that has not occurred.

Valuation is, therefore, a temporally, contextually, culturally, and conceptually determined process. Thus far, though, the complexity of the comparison between military advantage and the resultant destruction or damage has been explored only in its two-dimensional aspect. Regrettably, it is necessary to complicate matters further by factoring in a third dimension: environmental versus human (as opposed to military advantage) valuation. This dimension is present in two contexts: (1) risk to military personnel, and (2) nonenvironmental collateral damage. Several hypotheticals may help illustrate the point.

Assume shoulder-launched surface-to-air missiles (SAM) are occasionally fired at military aircraft from a residential district along the only feasible route to the target area. Though the risk to the aircraft is de minimis in light of the planned flight profile, it remains theoretically possible that a lucky hit might be scored. Can the entire residential area be bombed in hope of killing the lone soldier who launches the SAMs? Obviously not. It is easy to make this calculation for two reasons. First, the jus in bello is neutral; there are no "bad guys." In this hypothetical, a remote risk to the life of one combatant is being weighed against certain risk to the lives of scores of civilians. That they are enemy civilians does not shift the balance. Second, the more determinative fact is that the proportionality decision in this case is a human-human calculation.

However, what degree of environmental protection would justify the assumption of risk by our pilots? What if the SAMs were being fired from a dam, the destruction of which would destroy crop lands (anthropocentric valuation)? Harder still, what if destruction of the dam would destroy nonfood source animal habitats (intrinsic worth valuation)? We are back to the apples 
and oranges problem, albeit writ large. The task is no longer deciding whether to forgo gain, but instead whether to assume risk to protect the environment. Of course, the reflexive response is that environmental values cannot be balanced against human life, or even human suffering. But of course they can, assuming that the very concept of environmental protection in warfare is valid. Whenever a decision is made to forgo or alter an operation that otherwise meets the requirements of military necessity, the benefits of that necessity are lost. Since militarily necessary operations often are intended to lessen risk, either in the short or in the long term, a balance with human values implicitly has been made. The only way to avoid having to balance human and environmental values is to adopt a purely anthropocentric perspective in which protection of the environment is merely a byproduct. What this demonstrates is that treating the environment qua environment in making proportionality calculations muddies the waters of an already complicated process.

Yet another iteration of complexity is that in certain circumstances it will be necessary to recognize that nonenvironmental risk to the targeted party, either directly or collaterally, may be increased by extending protection to the environment. For instance, should an avenue of attack that might devastate a fragile amphibian habitat be avoided if the only viable alternative will result in damaged farm land? An even broader scenario can be painted by giving the concept of military necessity wide play. Because military necessity contributes to the success of one of the belligerents, it may also hasten the end of hostilities. Thus putting aside the optimal means of securing a militarily necessary objective in the name of environmental protection may in fact lengthen hostilities, thereby negatively affecting human values.

An obstacle to performing precise proportionality calculations is also apparent in determining what damage to weigh. The preceding discussion of military necessity raised the problem of likelihood of occurrence. Proportionality analysis involves an analogous difficulty in the form of uncertainty as to likelihood of harm. Simply put, when balancing collateral damage against military advantage, should the weight of possible damage be adjusted according to how likely the damage is to occur? Of course it should, but the problem is that whereas fairly reliable data is available on the effect of typical collateral damage (deaths, destruction of property, etc.), it is not available with regard to environmental damage. As the Gulf War demonstrated, estimates of the nature and quantum of environmental destruction can fall far from the mark.

Desert Storm highlighted a related problem. In addition to the difficulties of determining what damage will be caused, there is that of deciding how far down the chain of causation to proceed. During the Gulf War, aerial bombing brought criticism from some about its "reverberating effects." William Arkin, for instance, has written in detail about the unintended effects on civilians of the bombing of electrical targets. ${ }^{272}$ How should proportionality analysis be conducted when efforts to take down obvious military objectives, such as command and control nets, result in hospitals losing electricity or in similar

272. See ARKIN, supra note 269, at ch. 9. 
harms to noncombatants? What responsibility do commanders have to consider reverberating effects in their legitimacy analysis?

The environment can only exacerbate such quandaries. Recall the flap over the purported "Lorenz Effect," in which a butterfly beating its wings in Tokyo causes a thunderstorm in New York. ${ }^{273}$ The point is that when dealing with the environment, one is making calculations based on incredibly intertwined global relationships among the environment's seemingly infinite components. Unfortunately, despite the advances of science, we are only beginning to unravel this complexity. How, then, does one identify and take into account environmental reverberating effects? What level of environmental knowledge should be required of the commander making such assessments? To what degree must the commander attempt to ascertain potentially reverberating environmental effects? Do environmental engineers need to join judge advocates in command posts to ensure that commanders stay within the somewhat fuzzy confines of the law? These questions will prove particularly problematic because the valuation dynamics noted earlier in this section will influence each of the reverberating effects, which themselves may or may not be incorporated into the balancing process.

Ultimately, it might even be asked whether it is appropriate to apply the customary law of proportionality to environmental concerns at all, for there is certainly no longstanding practice of safeguarding the environment per se during armed conflict. Arguably, environmental benefits should be solely derivative, i.e., resulting from traditional customary law protections. For example, destruction of fish on a trout farm can be seen in terms of the customary law category of civilian objects. However, what would be the significance of an act that rendered the fish stock infertile? Is that the kind of damage to civilian objects contemplated in our customary law? This matter becomes more complicated still as we move beyond anthropocentric protections. Assume that the fish are swimming free and not used as a food source. To what extent would the international community demonstrate opinio juris sive necessitatis in such a case? It is one thing to argue that the customary law of proportionality must be flexible enough to provide protection to new objects that fall into traditionally protected categories. It is quite another to argue in the absence of state practice that protections should apply to newly recognized categories.

Hopefully, this discussion will have served to display again the complexity of factoring environmental considerations into the application of traditional law of war principles, in this case proportionality. Though some scholars might herald the demise of proportionality analysis, ${ }^{274}$ it remains a useful tool for securing humanitarian-and environmental-values during armed conflict. But it is no panacea; environmental considerations will

273. See generally JAMES GLEICK, CHAOS: MAKING A NEW SCIENCE 9-31 (1987) (discussing use of Lorenz (or Butterfly) Effect in chaos theory).

274. One distinguished international law scholar suggested during the Gulf War that "[t]he enormous devastation that did result from the massive aerial attacks suggests that the legal standards of distinction and proportionality did not have much practical effect." Oscar Schachter, United Nations Law in the Gulf Conflict, 85 AM. J. INT'L L. 452, 466 (1991). This is a minority opinion. Most commentators characterize the air campaign as well within the bounds of legality. See, e.g., Roberts, supra note 18 , at 41. 
complicate reliance on the principle, if only because it will be difficult to achieve consensus on what is and is not proportional. Thus, proportionality is likely to serve as a completely predictable constraint in only the most aggravated cases of environmental damage during armed conflict.

\section{Humanity}

The principle of humanity prohibits methods and means of warfare that are inhumane ${ }^{275}$ It is theoretically implicit in both military necessity and proportionality, but merits separate characterization in order to highlight particular prohibitions, such as those forbidding indiscriminate techniques ${ }^{276}$ and unnecessary suffering. That environmental destruction can easily violate the principle of humanity should be obvious. Water supplies can be poisoned, destruction of food sources can result in the starvation of innocents, or air quality can be so lowered that respiratory distress results. Of particular concern is the environment's susceptibility to indiscriminate use or damage. Destruction of the Huayuankow Dam is a classic example of an indiscriminate act with disastrous environmental consequences. ${ }^{277}$ Other theoretical uses of the environment, such as generating tidal waves or earthquakes, changing climate, or creating wetlands, are also inherently indiscriminate; once they are set in motion, their effects cannot be easily controlled. Given current technologies, it is difficult to envision an attack employing the environment that permits much discrimination at all.

Conceptually, the principle of humanity is overwhelmingly anthropocentric in nature. After all, it is labeled humanity. Nevertheless, the humanity principle is less utilitarian than the other customary principles, for it is not necessary to conduct a balancing test when applying it. In fact, any balancing that is required to assess humanity (e.g., in determining whether the suffering was "necessary") will probably be accounted for during the military necessity and proportionality analyses. If we put this cumulative component of humanity aside, the bulk of what remains are $a b$ initio prohibitions on activities that are not so much inhumane as inhuman. They are acts we intuitively recognize as inherently wrongful regardless of the context in which they occur. In a sense, they are violative of the "dictates of public conscience."

275. Among the first formal expressions of the principle was the St. Petersburg Declaration of 1868. The Declaration provided:

Considering that the progress of civilization should have the effect of alleviating, as much as possible the calamities of war;

That the only legitimate object which states should endeavor to accomplish during war is to weaken the military force of the enemy;

That for this purpose, it is sufficient to disable the greatest possible number of men;

That this object would be exceeded by the employment of arms which uselessly aggravate the sufferings of disabled men, or render their death inevitable;

That the employment of such arms would, therefore, be contrary to the laws of humanity.

Declaration of St. Petersburg, 1868, supra note 259, at 95 .

276. An indiscriminate technique insufficiently distinguishes protected persons (e.g., civilians) and objects from legitimate military objectives.

277. See supra text accompanying note 17. 
The concept of an inherently wrongful act may offer an avenue for expanding protection of the environment. As was noted, the central difficulty with military necessity and proportionality is comparative valuation. What the principle of humanity offers is an opportunity to move beyond that conundrum to the relatively simpler prospect of forging agreement on those things that civilized people just don't do. The immediate obstacle to doing this in the environmental context is that the principle of humanity generally is not thought of as applicable to anything other than immediate human suffering. Thus, when environmental violence such as that which occurred during the Gulf War is considered, the analysis tends to be in terms of proportionality or necessity, not in terms of humanity. Legalistic minutiae aside, though, the global community viewed the acts as "just don't do that" violations, a cognitive perspective that best comports with humanity analysis. Arguably, the world's reaction may portend the beginning of a subtle expansion of the principle. The shift would be from a prescription understood within the "there are certain things that you do not do to human beings" paradigm to that of "there are certain things that human beings do not do." This would temper disputes and avoid confusion about the relative value of dissimilar objects and goals.

Despite the appeal of a process that eases the inherent difficulties of balancing tests, the risk of this tack is great. It presumes that in some cases environmental damage should be avoided regardless of the cost to humanity. Perhaps in truly extreme cases of environmental damage in which a correspondingly high level of human suffering is inevitable, or in which the likelihood of accruing military advantage is very low, this technique could be used as prescriptive shorthand for humanitarian concerns. In other words, human suffering would not be ignored, but instead would simply be evaluated by a measure that offers ease of application. Such prescriptions could be crafted in terms of type of technique (e.g., oil spills), quantum of damage (e.g., long-term, widespread, and severe), target (e.g., the atmosphere), or any combination thereof. The defining characteristic, however, must be that it is not necessary to conduct a complex analysis of human suffering because the latter is presumed based on the level of environmental damage. Thus, while the approach may offer some benefits, any movement in this direction should proceed very cautiously.

\section{Treaty Based Jus in Bello}

\section{Hague IV}

The Hague Conventions reflected changes in the nature of warfare that occurred with the Napoleonic Wars. They marked the evolution of war into a national endeavor, fought on a grand scale by armies sometimes numbering in the hundreds of thousands, and resulting in previously unimaginable carnage. This transformation led to efforts to limit the effects of armed conflict. One of the earliest was the First Hague Peace Conference, convened at the urging of Czar Nicholas II in 1899. The Conference produced three 
instruments designed to limit armaments and their effects. ${ }^{278}$ In 1907, a Second Hague Peace Conference was assembled on the initiative of Theodore Roosevelt. Of the thirteen conventions that issued, Hague IV, which governs the conduct of land warfare, is environmentally relevant today. ${ }^{279}$ It remains in effect for its signatories, though party status is relatively unimportant because most of the treaty is now considered customary international law. ${ }^{280}$ In fact, "Hague Law" has become a general term of reference for laws of armed conflict designed to limit the methods and means of warfare.

Article 22 of Hague IV codifies the foundational customary law of war principle mentioned earlier, that the "right of belligerents to adopt means of injuring the enemy is not unlimited." 281 This principle is consistently cited as a conceptual basis for environmental prescriptions. ${ }^{282}$ Also directly relevant is article 23(e), which forbids the employment of "arms, projectiles or material calculated to cause unnecessary suffering." ${ }^{283}$ It applies to the environment in a manner analogous to the unnecessary suffering component of the humanity principle. As it is treaty rather than customary law, significant expansion of article 23(e) beyond its intended anthropocentric application is unlikely. Instead, evolution in that direction will probably emanate first from its customary law counterpart. ${ }^{284}$

The most important Hague IV provision applicable to environmental damage is article $23(\mathrm{~g})$. It codifies the classic military necessity principle by prohibiting acts that "destroy or seize the enemy's property, unless such destruction or seizure be imperatively demanded by the necessities of war." 285 Though there is occasional discussion over whether the article is intended to protect all property or only state property, the better view as a matter of law, and that adopted by both the U.S. Army and the ICRC, is that it covers any property, wherever situated and however owned. ${ }^{286}$

Since article $23(\mathrm{~g})$ is the codification of the military necessity principle, the earlier discussion of that principle also applies here. ${ }^{287}$ One further issue

278. These Declarations included a ban on launching projectiles or explosives from the air, a prohibition on the use of projectiles containing asphyxiating or deleterious gases, and a ban on bullets that expand or flatten in the body (Dum Dum bullets). See Final Act of the International Peace Conference, July 29, 1899, reprinted in 1 AM. J. INT'L L. 103 (Supp. 1907); Declaration Concerning Asphyxiating Gases, July 29, 1899, reprinted in 1 AM. J. INT'L L. 157 (Supp. 1907).

279. See Hague IV, supra note 130.

280. This status was recognized by the International Military Tribunal in 1939. See International Military Tribunal (Nuremberg), Judgment and Sentences, Oct. 1, 1946, excerpted in MYRES MCDougaL \& W. MiChAEL REISMAN, INTERNATIONAL LAW IN CONTEMPORARY PERSPECTIVE 1043, 1050 (1981).

281. Hague IV, supra note 130, art. 22.

282. For a pre-Gulf War argument along these lines, see Best, supra note 20.

283. Hague IV, supra note 130, art. 23(e).

284. This contention is not universally accepted. One commentator has argued by reference to the French text that article 23(e) "suffering" includes "property damage, environmental damage, or damage to anything." Leibler, supra note 185 , at 100 . This is an accurate characterization if the damage causes direct human suffering. However, an extension to property or environmental damage per se is not supportable. At any rate, such damage would likely be prohibited under article 23(g).

285. Hague IV, supra note 130 , art. 23(g).

286. See 2 DEPARTMENT OF THE ARMY, INTERNATIONAL LAW 174 (Pamphlet No. 27-161-2, 1962) [hereinafier ARP 27-161-2]; Pictet, supra note 263, at 301.

287. Treaty law may, of course, apply with different force than does customary law. As the ICJ has noted, "even if a treaty norm and a customary norm . . . were to have exactly the same content, this would not be a reason for the Court to take the view that the operation of the treaty process must 
bearing on environmental damage revolves around the definition of "property." There is little question that article $23(\mathrm{~g})$ applies to tangible property such as land, cattle, crops, or water supplies. In fact, the War Crimes Commission cited article $23(\mathrm{~g})$ in charges against ten German administrators of Polish forests for the unnecessary destruction of timber resources. ${ }^{288}$ Its applicability in other environmental contexts is not as clearcut. For instance, is the atmosphere "property"? What about climate or the ozone layer? How would destruction of a straddling stock of fish or a migratory bird species be handled? These examples illustrate the determinative importance of evolving property concepts to contemporary and future understandings of article $23(\mathrm{~g})$.

A second key Hague IV provision relevant to environmental protection is article 55. It provides that a belligerent occupying enemy territory "shall be regarded only as administrator and usufructuary of public buildings, real estate, forests, and agricultural estates belonging to the hostile State, and situated in the occupied country. [The occupier] must safeguard the capital of these properties, and administer them in accordance with the rules of usufruct." 289 As an usufructuary, the occupying power has the right to enjoy public property, including the right reasonably to exploit it for its natural resources. However, it may not permanently alter or destroy the property. By its own terms, the article does not become effective until open hostilities have ended in an area and a state of occupation has been declared, and it is limited to abuse or destruction of the four categories delineated. If hostilities in the area recommence, then Hague protection reverts to article $23(\mathrm{~g})$ military necessity.

Note should also be taken of the Martens Clause found in the preamble to each of the Hague Conventions. Given the novelty of environmental considerations in warfare, it could prove to be a key protection afforded by Hague IV:

Until a more complete code of laws has been issued, the high Contracting Parties deem it expedient to declare that, in cases not included in the Regulations adopted by them, the inhabitants and the belligerents remain under the protection and the rule of the principles of the laws of nations, as they result from the usages established among civilized peoples, from the laws of humanity, and from the dictates of the public conscience. ${ }^{200}$

A Martens Clause is also found in Protocol $\mathrm{I}^{291}$ and, as discussed earlier, generally is considered to be a principle of customary international law.

The major benefit of such a principle is that it operates during the evolution of prescriptive norms. As the law proper grapples with how to handle environmental issues, the "laws of humanity" and the "dictates of public conscience" theoretically will ensure a modicum of protection. Of

\footnotetext{
necessarily deprive the customary norm of its separate applicability." Military and Paramilitary Activities (Nicar. v. U.S.), 1986 I.C.J. 4, 84 (June 27).

288. See Leibler, supra note 185, at 106 (citing U.N. War Crimes Commission, Case No. 7150-469

(1948)).

289. Hague IV, supra note 130 , art. 55.

290. Id. pmbl.

291. Protocol I, supra note 8, art. 1, para. 2.
} 
course, the problem is that it is often difficult to extract specific prohibitions from "moral law and public opinion." As has been noted, for example, saturation bombing of cities and the practice of "dumping" bomb loads prior to returning to base during World War II "left the public conscience relatively undisturbed." 292 Much of the difficulty in determining whether a Martens situation has presented itself will result from the surfacing of crosscultural and intersocietal differences. There will certainly be differences of perception as to the content of "the laws of humanity" and "the dictates of public conscience." Nonetheless, the provision at least offers a final line of defense to those facing legalistic explanations of why the traditional law of war does not apply in a particular situation.

How useful is Hague IV in limiting environmental damage during warfare? In the view of some, very much so. One distinguished commentator argued in 1992, for example, that had the Hague IV principles "been observed by Iraq, there would have been no significant violation of the Kuwaiti environment." 293 Similarly, the DOD Report on the Gulf War stated that the oil spills and sabotage of the oil wells were violations of article $23 .{ }^{294}$ While probably accurate, such characterizations are fact-specific; they fail to demonstrate that the Hague IV prescriptions are sufficiently comprehensive or that they can be applied successfully in other scenarios. What if an amphibious operation actually had been imminent when the oil was spilled? What if the Iraqis merely had opened the valves on the oil wells and then set the pools ablaze as the DOD report noted they had not? Possibly more revealing still, what if the opponent had not been as universally ostracized as Saddam Hussein? Finally, what would have been the international reaction to the environmental destruction if the victim had been Israel or Iran instead of Kuwait? While it is certainly correct that Hague IV provides significant protection to the environment, these hypotheticals aptly illustrate potential fault lines. ${ }^{295}$

\section{Geneva Convention IV}

"Geneva law" is that component of the law of war, often labeled "humanitarian law," that protects certain categories of individuals and objects. Whereas Hague law governs what methods and means are appropriate in warfare, Geneva law delineates against what and whom those methods can be

292. See ARP 27-161-2, supra note 286, at 15.

293. Terry, supra note 92, at 63; see also Michael Bothe, Environmental Destruction as a Method of Warfare: Do We Need More Law?, 15 DISARMAMENT 101, 104 (1992) (asserting that Iraqi actions violated unnecessary suffering provision of article $23(e))$.

294. See DOD REPORT, supra note 69 , at $0-22$. Note that the Convention contains a general participation clause, i.e., a provision to the effect that the treaty applies only between parties, and then only if all belligerents are parties. See Hague IV, supra note 130, art. 2. Iraq was not a party to Hague IV. In 1907 it was still a part of the Ottoman Empire. Twelve years later Iraq became a British mandate, but Great Britain never acceded to Hague IV on its behalf. Therefore, when Iraq gained its independence in 1932 it did not have to acknowledge party status. Of course, the fact that the treaty is recognized as customary international law makes this point somewhat irrelevant.

295. Other Hague IV provisions that might bear on environmental damage in individual cases include the requirement to respect private property, see Hague IV, supra note 130 , art. 46, and the prohibition of pillage, see id. art. 47 . 
used. Thus, the two bodies of law are complementary. There is a long line of Geneva Conventions stretching back to 1864. Today, the four 1949 Geneva Conventions are the most universally recognized instruments in the law of armed conflict and are considered to have become in great part customary international law. For the purposes of this study, the most relevant is Geneva Convention IV, which governs the protection of civilians and civilian objects in war. 296

With regard to environmental destruction, article 53 is the highlight of Geneva Convention IV. It provides that "[a]ny destruction by the Occupying Power of real or personal property belonging individually or collectively to private persons, or to the State, or to other public authorities, or to social or cooperative organizations, is prohibited, except where such destruction is rendered absolutely necessary by military operations." ${ }^{297}$ Several characteristics of this prohibition are worthy of comment. First, though many objects are granted protection, it is limited, as in article 55 of Hague IV, to occupied territory. Extending protection beyond occupied territories was felt to be unnecessary on the basis that article 23(g) of Hague IV sufficed. ${ }^{298}$ Of course, also filling in the gap is the customary international law principle of military necessity. Thus, the criticism that has been leveled against the limited scope of article 53 may be valid if the provision is viewed in isolation, but in terms of practical impact during armed conflict, it is inconsequential. ${ }^{299}$

Although applying only to occupied territories, the provision does offer meaningful protection because environmental damage often occurs in such situations. Historically, this is particularly likely as an occupying force is being ejected. For instance, scorched-earth policies in occupied territory during World War II formed the basis for multiple war crimes prosecutions. ${ }^{300}$ More recently, much of the environmental damage that occurred in the Gulf War took place as a result of property destruction in occupied Kuwait, most notably destruction of the oil wells. In fact, when the Commission for International Due Process of Law prepared a draft indictment of Saddam Hussein and his key advisers for submission to the U.N. Secretary General, a violation of article 53 was specifically alleged. ${ }^{301}$ Most scholars and practitioners agree with this characterization of the actions of Iraq, ${ }^{302}$

296. Geneva Convention IV, supra note 10.

297. Id. art. 53.

298. See Pictet, supra note 263 , at 301.

299. See Richard A. Falk, The Environmental Law of War: An Introduction, in ENVIRONMENTAL PROTECTION AND THE LAW OF WAR, supra note 94, at 78, 88.

300. See, e.g., Hostage (U.S. v. List), 11 T.W.C. 759 (1950) (acquitting general who had ordered destruction during German evacuation of Norway on basis that destruction was necessary due to general's (mistaken) belief that Russians were pursuing his forces); see also High Command Case (U.S. v. Von Leeb), 11 T.W.C. 462 (1950) (involving destruction in Soviet Union).

301. See Luis Kutner \& Ved P. Nanda, Draft Indictment of Saddam Hussein, 20 DENV. J. INT'L L. \& POL'Y 91, 93 (1991). In specification 10 of charge I, the Iraqis were charged with having "destroyed the real and personal property of protected persons and the State of Kuwait; this destruction was not absolutely necessary to military operations and occurred for the most part after military operations had ceased." Id.

302. See, e.g., DOD REPORT, supra note 69, at O-22; McNeill, supra note 145, at 80; Roberts, supra note 18, at 39. Additionally, Professor Roberts and Mr. McNeill would concur with Michael Bothe that the actions constituted grave breaches under article 147. See Bothe, supra note 293, at 104. 
a state which had acceded to the Convention in 1956.

Article 53 is caveated with the proviso that the prohibition does not apply when destruction is "rendered absolutely necessary by military operations." ${ }^{303}$ This leads us back into the interpretive maze of the customary law principle's directness requirement. Although "absolutely" would seem to set a high standard-an extreme on the continuum of necessity, if you will-it is still subject to interpretation. As Jean Pictet has noted in his authoritative ICRC-sponsored commentary on the Convention, "[i]t is therefore to be feared that bad faith in the application of the reservation may render the proposed safeguards valueless; for unscrupulous recourse to the clause concerning military necessity would allow the Occupying Power to circumvent the prohibition set forth in the Convention." 304 To address this weakness, he urges occupying powers to interpret the provision reasonably and with a "sense of proportion in comparing the military advantages to be gained with the damage done." ${ }^{305}$ The catch-22 is that those states likely to follow Pictet's admonition are the ones that least need to be deterred from "unscrupulous recourse to the clause." At the same time, an unscrupulous belligerent is most likely to take advantage of the additional uncertainty that environmental concerns bring to necessity calculations.

Despite the difficulty in interpretation and application, one positive note is that article 147 of the Convention includes as grave breaches "extensive destruction . . . of property, not justified by military necessity and carried out unlawfully and wantonly." ${ }^{306}$ As a result, a violation of article 53 is a grave breach whenever the destruction involved is "extensive." Characterization as a grave breach is crucial because parties to the Convention are required to pass domestic legislation providing for the punishment of those who commit or order grave breaches. ${ }^{307}$ More significantly, a party is obligated to search for offenders and to bring them before its courts, regardless of their nationalities. ${ }^{308}$ Offenders may also, consistent with extradition agreements, be turned over to other states for prosecution. ${ }^{309}$ Therefore, while the prescription itself admits of imprecision, the sanctions mechanism should operate to heighten deterrence. Sadly, the Gulf War illustrated that it may not always have this effect, assuming that the DOD Report's characterization of the Iraqi actions as violations of articles 53 and 147 is accurate as a matter of law. ${ }^{310}$

Finally, some additional indirect protection for the environment is found in article 147's inclusion of "willful killing [and] willfully causing great suffering or serious injury to body or health" in the universe of grave breaches. ${ }^{311}$ Although this applies only to "protected persons" under the

\footnotetext{
303. Geneva Convention IV, supra note 10, art. 53.

304. Pictet, supra note 263, at 302.

305. Id.

306. Geneva Convention IV, supra note 10, art. 147.

307. See id. art. 146.

308. See id.

309. See id.

310. See DOD REPORT, supra note 69 , at $0-22$.

311. Geneva Convention IV, supra note 10, art. 147.
} 
convention, i.e., those who are "in the hands of a Party to the conflict or Occupying Power of which they are not nationals," 312 there are certainly many situations involving environmental damage that could have these results. The acts do have to be willful, an intent requirement that appears to exclude purely collateral injuries. ${ }^{313}$

Have the relevant Geneva Convention IV principles become recognized as customary international law in the fashion of their Hague counterparts? While there is no international judicial decision on point, the extensive dissemination of the principles through teaching, scholarship, and publication in law of war manuals would suggest they have been. Indeed, no law of war class or manual would be complete without a discussion of Geneva Convention IV. All significant players in the international arena are parties to this Convention, and state practice demonstrates a consensus that the norms expressed are obligatory. The fact that Geneva Convention IV exists as a treaty does not preclude it from evolving over time into customary law, despite the concerns that some have expressed. ${ }^{314}$ As a result, the normative Geneva prescriptions discussed above are almost certainly binding on parties and nonparties alike. ${ }^{315}$

\section{Protocol I}

In 1965 the Twentieth Conference of the Red Cross directed the ICRC to begin work on proposals for updating the law of war. This was in great part a response to an emerging belief that the nature of warfare had begun to experience a qualitative transformation that merited revision of the prescriptive norms governing its conduct. Accordingly, the ICRC convened the Diplomatic Conference on the Reaffirmation and Development of International Humanitarian Law Applicable in Armed Conflicts. The Conference, which met over four sessions between 1974 and 1977, was attended by representatives of well over one hundred nations and fifty intergovernmental

\section{Id. art. 4.}

313. See Pictet, supra note 263 , at 597.

314. The reasoning behind such concerns is as follows:

The large number of nations which accept the Geneva Conventions, rather than evidencing a development of well-accepted custom, may actually obscure the degree to which the treaties have become customary law. As parties to the treaties, nations may be simply following their conventional obligations rather than forging new customary practices. Because of this possibility, the Geneva Conventions paradoxically may remain conventional law rather than having evolved into customary law. Presumably, customs cannot develop when widely subscribed to conventions already exist.

Mark J. T. Caggiano, The Legitimacy of Environmental Destruction in Modern Warfare: Customary Substance Over Conventional Form, 20 B.C. ENVTL. AFF. L. REV. 479, 493 (1993) (footnotes omitted). However, recall that the International Military Tribunal found Hague IV to be customary law, see supra note 280 , even though by its own terms, it is limited in application to parties, see Hague IV, supra note 130 , art. 2. I doubt whether there is an inverse relationship between accession to a treaty and the customary character of its provisions. See Theodor Meron, The Geneva Conventions as Customary Law, 81 AM. J. INT'L L. 348 (1987).

315. See Vienna Convention, supra note 193, art. 38 ("Nothing . . . precludes a rule set forth in a treaty from becoming binding upon a third State as a customary rule of international law, recognized as such."); see also North Sea Continental Shelf (F.R.G. v. Den.) (F.R.G. v. Neth.), 1969 I.C.J. 4 (Feb. 20). 
or nongovernmental organizations. Additionally, eleven national liberation movements sent observers. In 1977 this conference adopted two "Protocols Additional" to the Geneva Conventions of 1949. Protocol I addressed international armed conflict. It is a particularly interesting product in that it combines elements of both Hague and Geneva law. The other, Protocol II, was designed to protect victims of noninternational armed conflict; it will not be discussed here.

The United States signed the protocols in 1978, and some six years later the Joint Chiefs of Staff were directed to develop a final position on ratification. ${ }^{316}$ Their conclusions, in which the Office of the Secretary of Defense and the Department of State concurred, recommended against ratification of Protocol I, and President Reagan accepted that advice, calling the Protocol "fundamentally and irreconcilably flawed,"317 a position which is under review by officials of the current administration. Despite its rejection of the treaty, the United States does acknowledge that much of Protocol I is customary law and, therefore, binding on its armed forces. ${ }^{318}$ This position has important implications for applicability of the treaty. For example, if the position is accurate, the customary provisions were applicable during the Gulf War, even though at the time the United States, France, the United Kingdom, and Iraq were nonparties. ${ }^{319}$

The bulk of the relevant prescriptions found in the Protocol safeguard the environment "indirectly," either through anthropocentrically based protections or through the extension of traditional concepts designed for purposes other than environmental protection. ${ }^{320}$ However, Protocol I was the first instrument intended exclusively for armed conflict to provide direct environmental protection. The idea of doing so initially surfaced at the Conference of Government Experts in 1972.321 This ICRC-sponsored body was tasked with laying the groundwork for the effort to update the law of armed conflict. Interestingly, despite a suggestion that the environment per se be granted protection, the preliminary ICRC draft did not contain any

316. See Agora: The U.S. Decision Not to Ratify Protocol I to the Geneva Conventions on the Protection of War Victims, 81 AM. J. INT'L L. 910, 916 (1987) [hereinafter Agora].

317. Letter of Transmittal from President Ronald Reagan, Protocol II Additional to the 1949 Geneva Conventions, and Relating to the Protection of Victims of Non-International Armed Conflicts, S. TREATY Doc. No. 2, 100th Cong. (1987), reprinted in Agora, supra note 316, at 911.

318. See INTERNATIONAL AND OPERATIONS LAW Div., OFFICE OF THE JUdGE ADVOCATE GEN., DEP'T OF THE AIR FORCE, OPERATIONS LAW DEPLOYMENT DESKBOOK tab 12 [hereinafter DEPLOYMENT DESKBOOK] (summarizing Protocol I and stating U.S. position on key articles).

319. The interesting question is whether all the parties can agree on which provisions are customary. For an analysis of the Protocol as customary law in the Gulf War, see Christopher Greenwood, Customary International Law and the First Geneva Protocol of 1977 in the Gulf Conflict, in THE GULF WAR 1990-91 IN INTERNATIONAL AND ENGLISH LAW (Peter Rowe ed., 1993).

320. See ICRC COMMENTARY, supra note 17, at 661 .

321. The proposal submitted by the experts of Czechoslovakia, the German Democratic Republic, and Hungary read: "It is forbidden to use weapons, projectiles or other means and methods which upset the balance of the natural living and environmental conditions." 2 INTERNATIONAL COMM. OF THE RED CROSS, REPORT ON THE WORK OF THE CONFERENCE OF GOVERNMENT EXPERTS ON THE REAFFIRMATION AND DEVELOPMENT OF INTERNATIONAL HUMANITARIAN LAW APPLICABLE IN ARMED CONFLICTS 51 (1972). The proposal submitted by the experts of Poland forbade the use of "methods and means which destroy the natural human environment." Id. at 52. 
provisions expressly addressing the topic. ${ }^{322}$ After several of the delegations pressed the issue, an informal working group, known as "Biotope," was established within Conference Committee III to consider proposals for environmental provisions. ${ }^{323}$ The working group recommended two types of articles. First, it recommended articles that tended to treat the environment anthropocentrically-that is, as meriting protection because environmental damage can lead to human suffering. ${ }^{324}$ Efforts in this direction led to the adoption of article $55 .{ }^{325}$ On the other hand, some members, recalling the environmental destruction of the Vietnam War, urged adoption of a standard unqualified by the human factor-an intrinsic value approach. ${ }^{326}$ This led to adoption of the article 35(3) restriction on means and methods of warfare that damage the environment. ${ }^{327}$

Articles 35(3) and 55 represented the furthest steps toward safeguarding the environment in any international law instrument. The two provisions are complementary: The former is basically a Hague law variant (limits on methods and means of warfare), while the latter is a Geneva law protection (protection of civilians and civilian objects). To foster this relationship, they employ analogous standards. ${ }^{328}$

As mentioned earlier, inclusion of both provisions was in part an effort to respond equally to the anthropocentric and intrinsic value camps. ${ }^{329}$ Note the absence in article 35(3) of any connection to, or balancing with, human values. This is particularly interesting because it is an "intrinsic value plus" standard. Basic intrinsic valuation requires assessing more than human worth; it does not preclude balancing environmental and human values once the weighing process is complete. Article 35(3), however, operates independently of human variables. In contrast, article 55(1) focuses on the damage's "prejudice [to] the health or survival of the population," a classically anthropocentric formulation. ${ }^{330}$

The express Biotope rationale for retaining the two approaches was that

322. See ICRC COMMENTARY, supra note 17 , para. 2129 , at 662 .

323. See id., para. 2130 , at $663 ; 15$ OFFICIAL RECORDS OF THE DIPLOMATIC CONFERENCE ON THE REAFFIRMATION AND DEVELOPMENT OF INTERNATIONAL HUMANITARIAN LAW APPLICABLE IN ARMED CONFLICTS 220 [hereinafter O.R.].

324. See 15 O.R., supra note 323 , at $358-59$.

325. See $14 \mathrm{id}$. at $405-06$.

326. See 15 id. at $358-59$.

327. See 14 id. at 404 .

328. See supra text accompanying notes $48-49$ (quoting articles $35(3)$ and 55).

329. Inclusion of both raised a few hackles. The United Kingdom, for example, went on record disapproving inclusion of article 35(3) in this section, and interpreted it as a mere repetition of article 55. It is particularly important that the United Kingdom viewed the provisions as protecting the environment in order to protect civilians living in it. See 6 O.R., supra note 323, at 118.

330. See Protocol I, supra note 8, art. 55, para. 1. For purposes of clarity, it should be noted that article 55 falls under part IV, chapter III, entitled "Civilian Objects." Therefore, it does not protect military objectives. In contrast, there is no such structural limitation with regard to article 35(3). Additionally, note that article 55 refers to the "population" without the adjective "civilian." The official record makes clear that this omission was intentional - the goal was to extend the protection to the whole population, since the damage was to be long-term. See 15 O.R., supra note 323, at 360 . Finally, "health" is used in the provision to provide protection beyond that needed for bare survival. Effects that would pose a serious blow to health-such as congenital defects or deformities-would, therefore, be encompassed within the meaning of the provision. See $15 \mathrm{id}$. at 281 . 
whereas article 55 provides for the protection of the civilian population, article $35(3)$ is an unnecessary suffering standard. That may explain the methods/means versus civilian population distinction, but it does not explain the absence of reference either to humans or to balancing. In fact, the ICRC commentary on the issue is fairly clear. It states that article $35(3)$

is a matter not only of protecting the natural environment against the use of weapons or techniques deliberately directed against it, nor merely of protecting the population and the combatants of the countries at war against any of these effects, but also one of protecting the natural environment itself. ${ }^{33 !}$

If article 35(3) is about unnecessary suffering, then that suffering extends beyond humans to the "suffering" of the environment.

Most opposition to these provisions has centered on the definition of "widespread, long-term, and severe." Use of the conjunctive "and" is particularly problematic, for so interpreted the articles mandate a three-part test which is nearly impossible to meet except in the most egregious cases. Unfortunately, there is very little indication in the negotiating history of what the delegates intended by the phrase. Some referred to "long-term" as a period measured in decades. ${ }^{332}$ In fact, other than a passing mention that the battlefield damage in France during the First World War was not of the type contemplated, ${ }^{333}$ little emanated from the conferences to clarify matters. ${ }^{334}$ This lack of clarity is one basis for the objections of the United States and other countries. ${ }^{335}$

Attempts have been made to remedy this flaw, though they have not been international in scope. For instance, the German law of war manual defines the quantum of damage necessary as "a major interference with human life or natural resources which considerably exceeds the battlefield damage to be regularly expected in a war." ${ }^{336}$ Surprisingly, some of the best guidance has come from the military of the key state that has not ratified Protocol I-the United States. In its Operational Law Handbook, the Army Judge Advocate General School asserts that "long-standing" should be understood as decades; "widespread" probably means "several hundred square kilometers . . . [and] 'severe' can be explained by Article 55's reference to any act that 'prejudices the health or survival of the population." 337 The "widespread" definition is taken from ENMOD. This is an interesting approach given the fact that an Understanding was appended to ENMOD disclaiming any intention for its definitions to apply to other instruments-an unstated but obvious reference

331. ICRC COMMENTARY, supra note 17, para. 1441, at 410.

332. See 15 O.R., supra note 323 , at 268.

333. See id. at 269.

334. According to the ICRC Commentary, "[i]t appeared to be a widely shared assumption that battlefield damage incidental to conventional warfare would not normally be proscribed by this provision." ICRC COMMENTARY, supra note 17, para. 1454, at 417 (citations omitted).

335. See DOCUMENTS ON THE LAW OF WAR 461-63 (Adam Roberts \& Richard Guelff eds., 1982) (reporting reservations to Protocol).

336. GERMAN MANUAL, supra note 168, para. 403. However, note that this definition complements a provision in the manual that was developed from both Protocol I and ENMOD.

337. OPERATIONAL LAW HANDBOOK, supra note 179, at 5-8. According to the handbook, most of the damage that occurred during World War II would not have met this threshold. See id. 
to Protocol I. From the perspective of the overall development of the environmental law of war, the Army's reference to human "health and survival" is more important. To use this standard in setting an article 35(3) threshold is to come down firmly in the anthropocentric camp, thereby neglecting the drafters' rationale for including two distinct environmental provisions.

Articles 35(3) and 55 present other interpretive challenges. Some commentators are concerned that the "may be expected" language creates a subjective "should have known" standard that will be used to judge commanders. ${ }^{338}$ If that is so, they argue, war crimes charges could be based on incidental environmental damage caused in the course of otherwise valid military operations. ${ }^{339}$ These concerns are overstated. The "expected" verbiage is obviously designed to preclude any argument that since collateral damage is not "intended," it is not encompassed in the prohibition. Isn't that as it should be? A prohibition on excessive collateral damage is hardly novel in the law of war. More to the point, the commentators are entirely accurate-commanders could be made subject to a "should have known standard." But that is the standard of criminal responsibility imposed in the domestic law of many states. Under the Uniform Code of Military Justice, for instance, commanders are already held criminally responsible for operational consequences about which they should have known. ${ }^{340}$ Lack of actual knowledge is a mitigating factor, not a defense based on the absence of an element of the offense.

What should be of far greater concern to the operational commander than definitional legerdemain or questionable scienter standards is that the provisions are devoid of reference to military necessity or proportionality. Any action taken by a commander that reaches the "long-term, widespread, and severe" threshold will violate the prescriptions even if it is militarily necessary and clearly proportional. No balancing occurs beyond this point. Especially troubling is the possibility that there may be human values, military advantages aside, that outweigh the environmental protection being afforded. ${ }^{341}$

338. In fact, that appears to have been the intent. The ICRC Commentary explains that the English text originally read "calculated to cause," whereas the French text used the phrase "de nature à." The English iteration suggested that the mental state required was one of intent or deliberation, whereas the French was more restrictive. Therefore, the Conference discarded the "calculated to cause" phraseology, replacing it with "intended, or may be expected." See ICRC COMMENTARY, supra note 17, para. 1458, at 418.

339. See Roberts, supra note 50, at 146-48. He argues that the "standards set forth in articles 35(3) and 55 are too ambiguous and subject to diverging interpretation to be workable. They could conceivably make military commanders and political leaders subject to prosecution for committing war crimes if they 'should have known' their actions would result in proscribed damage to the environment." Id. at 148. This assertion confuses possibly valid criticism of substantive legal standards with issues of mens rea.

340. See JoInt SERv. COMM. ON MILITARY JUSTICE, MANUAL FOR COURTS-MARTIAL, UNITED STATES \& 16a(3)(b) (pt. IV 1995). The explanation to article 92 of the code indicates that dereliction of duty may be charged using this standard: "[a]ctual knowledge need not be shown if the individual reasonably should have known of the duties." Id. $\S 16 \mathrm{c}(3)(\mathrm{b})$.

341. The issue is not an "either-or" proposition-it is a question of balance. Even intrinsic value advocates would agree that environmental values can be outweighed by human ones. The precise balance depends on the circumstances. 
Imagine, for instance, a large population center at risk of falling to enemy forces operating from forested terrain surrounding it. The forest effectively serves as a sanctuary for the attackers. To complicate matters, prior instances of occupation by the enemy have revealed a callous, wanton occupier with little regard for the civilian population. The only option available to the defending commander is to destroy the forest surrounding the city, but the sole method available for doing so quickly will result in long-term, widespread, and severe destruction of the forest's flora and fauna. On the other hand, denial of sanctuary will force the enemy to withdraw. Under article 35(3), the commander seemingly would be precluded from taking the action despite the potential for tragic human suffering should the enemy occupy the city. Yet absent article 35(3), the commander's proposed course of action would clearly meet the requirements of military necessity and proportionality.

That is one side of the coin, namely, whether the articles raise the standard of protection too high by excluding from the process important considerations that safeguard human values. On the other side is the debate about whether the standard of protection is lowered by the articles. Professor Wil Verwey has argued that it very well might, by pointing to the general principle of law that lex specialis applies over lex generalis. According to this argument, an action that does not cause widespread, long-term, or severe damage will not be prohibited because it is otherwise disproportionate or causes unnecessary suffering. ${ }^{342}$ The better view, however, is that neither provision has such an effect. First, the lex specialis principle applies in situations in which norms appear to conflict. It is a principle of resolution. Here it can be argued that proportionality and unnecessary suffering are complemented by the Protocol provisions and vice versa; they are each designed to further humanitarian concerns ${ }^{343}$ Much more importantly, the inclusion of environment-specific prescriptions was not intended to forgo protection already in place. Nor did the Diplomatic Conference use articles 35(3) and 55 merely to clarify existing norms, a fact illustrated by the differing perspectives reflected in the two. Instead, the purpose was obvious-to enhance protection of the environment. Arguments to the contrary ignore the historical, political, and social milieu from which Protocol I emerged, as well as the principle of international law that treaties are to be interpreted in accordance with their context, object, and purpose. ${ }^{344}$

Another interpretive challenge is determining what to make of the "care shall be taken" language in the first sentence of article 55. No such exhortation appears in article 35(3). Though reference to "taking care" might at first glance appear to set a low standard, article 55 continues by prohibiting methods or means that would result in the requisite damage. Thus, the phrase is actually a hortatory provision that encourages greater protection of the environment than the minimum standard set forth in the next sentence. This

342. See Verwey, Additional Rules, supra note 13, at 2.

343. Bear in mind that proportionality and unnecessary suffering are principles of law, not war.

344. See Vienna Convention, supra note 193, art. 31, para. 1 ("A treaty shall be interpreted in good faith in accordance with the ordinary meaning to be given to the terms of the treaty in their context and in the light of its object and purpose."). 
makes particular sense in the context of an anthropocentrically based article: One should always strive to improve the protection of humans from the dangers of war. Perhaps, then, the provision is intended to address situations involving methods or means not designed to damage the environment. ${ }^{345} \mathrm{By}$ this interpretation, the care standard is a collateral damage provision. Alternatively, it might be simply hortatory, and merit no formal prescriptive valance beyond that. ${ }^{346}$

In a sense, these articles, particularly article 35(3), are analogous to the "just don't do that" prohibitions discussed in conjunction with the humanity principle. ${ }^{347}$ Here we see the flip side of the benefits provided by such prohibitions. While they may obviate the necessity of engaging in complex balancing analysis, in certain unique circumstances they may also operate to bypass human values that could be fostered by the prohibited actions. Of course, any appraisal of the prescriptions must be based on an analysis of costs and benefits. Do the clear benefits offered by environment-specific provisions outweigh the costs generated, in the unlikely event that actions forbidden by Protocol I foster human values? The answer depends, as it did with the customary international law balancing tests, on the relative assessment of human and environmental values. This returns us to the anthropocentric versus intrinsic value debate.

In the search for the meaning of the prescriptions, a distracting twist is the assertion that the use of nuclear weapons might be prohibited by the Protocol. After all, while no weapon is more destructive, many strategists have argued that the very destructiveness of nuclear weapons is what provides the greatest protection to human values-a protection that takes the form of deterrence. Concerns have been expressed that if Protocol I were held applicable to nuclear weapons, "the careful balance fashioned with the other nuclear powers in existing agreements affecting those weapons could be adversely impacted." ${ }^{348}$ However, although the legality of nuclear weapons is a valid topic for discussion in international law circles, the applicability of articles 35(3) and 55 is not. From the very beginning, it was clear that the Protocol provisions were not meant to reach nuclear weapons. When the ICRC first provided draft protocols to the Diplomatic Conference for consideration, it specifically noted that they were not intended to encompass atomic, chemical, or bacteriological weapons because those weapons were already the subject of other international instruments. Later, the United States, France, and the United Kingdom, among other states, reiterated the exclusion of nuclear weapons from the reach of the Protocol provisions. In fact, the only country that appeared to adopt the position that nuclear weapons were covered was India. ${ }^{349}$

345. See MiChael BOthe ET AL., NEW RULES FOR ViCtiMS OF ARMEd CONFLICTS 345-46 (1982).

346. Professor Verwey has observed that the ICRC has never claimed that the care standard of the first sentence was intended to extend the level of protection. See Verwey, Additional Rules, supra note 13 , at 3.

347. See supra Subsection III.B.3.

348. Terry, supra note 92 , at 64-65.

349. For discussions of this issue, see DEPLOYMENT DESKBOOK, supra note 318, tab 12, para. 1.7.1.4; Aldrich, supra note 50, at 718-19; Frits Kalshoven, Reaffirmation and Development of 
After all is said and done, how much protection do Protocol I's environmental provisions actually provide? The answer remains clouded, but the best estimate is that it is measurable. For instance, even in advance of the Gulf War, the ICRC Commentary noted that "[t]here is no doubt that article 55 will apply to the destruction of oil rigs resulting in oil gushing into the sea and leading to extensive damage such as that described in that article." $" 350$ With impressive foresight, it also addressed the tactic of setting oil facilities ablaze, noting that "it is hardly necessary to stress the grave danger that may ensue for the civilian population." 351

Yet some would counter that the standards are "too broad and too ambiguous for effective use in military operations." "352 This criticism is basically irrelevant because any action that might rise to the Protocol levels of harm would probably already be precluded by general principles such as proportionality. Still others suggest that the standard is too high to have any real effect. ${ }^{353}$ The position taken by the DOD's Gulf War Report falls squarely within the naysayer camp:

\footnotetext{
[T]here were questions as to whether the Iraqi actions would have violated its environmental provisions. During [the] treaty's negotiation, there was general agreement that one of its criteria for determining whether a violation had taken place ( "longterm") was measured in decades. It is not clear [whether] the damage Iraq caused, while severe in a layman's sense of the term, would meet the technical-legal use of the term in Protocol I. The prohibitions on the damage to the environment contained in Protocol I were not intended to prohibit battlefield damage caused by conventional operations and, in all likelihood, would not apply to Iraq's actions in the Persian Gulf War. ${ }^{354}$
}

While it may or may not be accurate to deny that the damage technically reached the Protocol I threshold, it certainly is quite a stretch to suggest that either the intentional spilling of nine million barrels of oil into the sea or the setting of over five hundred oil well fires is analogous to "battlefield damage caused by conventional operations." The ICRC's Hans-Peter Gasser has succinctly noted that "[a]s a legal statement this is questionable." ${ }^{355} \mathrm{He}$ is quite right. Though the level of damage caused by the Iraqi actions was overestimated, it would appear clear from the commentary that this was precisely the type of action that the drafters had in mind.

As noted earlier, the United States has chosen not to ratify Protocol I

Intermational Humanitarian Law Applicable in Armed Conflicts: The Diplomatic Conference, Geneva, 1974-1977, 9 NETH. Y.B. INT'L L. 107, 108-09 (1978).

350. ICRC COMMENTARY, supra note 17 , at $668-69$.

351. Id. at 669.

352. Matheson, supra note 50 , at 436. This contention is insupportable. Imagine a small state facing a large invasion force from the sea. Furthermore, assume that the human rights record of the aggressor force during occupation is dismal.he small state could foil amphibious operations by dumping oil into the path of the oncoming fleet, would not such an action be both proportionate and militarily necessary even though the damage caused would reach Protocol I levels?

353. See, e.g., Betsy Baker, Legal Protections for the Environment in Times of Armed Conflict, 33 VA. J. INT'L L. 352, 368 (1993).

354. DOD REPORT, supra note 69, at $0-27$.

355. Hans-Peter Gasser, The Protection of the Environment During Armed Conflict and Other Military Operations, Paper Presented at the Symposium on the Protection of the Environment During Armed Conflict and Operations Other Than War, in NWC SYMPOSIUM PAPERS, supra note 13 (manuscript at $10 \mathrm{n.4}$, on file with The Yale Journal of International Law). 
(though over 130 other states have), ${ }^{356}$ and has objected specifically to those provisions that are directed to environmental protection. Are they nevertheless declaratory of customary international law? A number of commentators have argued that articles $35(3)$ and 55 may be. ${ }^{357}$ The better argument is that while there may be an emergent "operational code" regarding environmental damage during warfare, it is premature to assert that customary law in the classic sense has solidified. ${ }^{358}$ Lack of international unanimity among the relevant actors, most notably the United States, is ample evidence of this fact. The ICRC also takes the position that articles $35(3)$ and 55 have not attained the status of customary law, ${ }^{359}$ which explains its aggressive dissemination efforts, particularly vis-à-vis its new environmental law of war guidelines.

While articles $35(3)$ and 55 are the only environment-specific prescriptions found in Protocol I, many of its other provisions also bear on issues of warfare and the environment. Some simply further codify elements of the law of war that already have been addressed. For instance, article 35(1) notes that the right of the parties to choose methods or means of warfare is not unlimited; ${ }^{360}$ article $35(2)$ expresses the customary unnecessary suffering prohibition; ${ }^{361}$ article 51 proscribes indiscriminate attacks, ${ }^{362}$ and both articles $51^{363}$ and $57^{364}$ mandate proportionality analysis. General concepts relevant to the environment are implicit in several other provisions. The requirement to distinguish civilian from military objects in articles $48^{365}$ and

356. A current listing of the parties is maintained by the ICRC at the net site (visited Oct. 23, 1996) <http://www.icrc.ch/icrcnews > .

357. See, e.g., MOORE, supra note 76 , at 78 (noting that articles $35(3)$ and 55 "may be declaratory of a rapidly developing customary international law").

358. For a discussion of operational codes and myth systems, see W. MICHAEL REISMAN, JURISPRUDENCE: UNDERSTANDING AND SHAPING LAW 23-25 (1987); W. MICHAEL REISMAN \& JAMES E. BAKER, REGULATING COVERT ACTION 23-24 (1992).

359. See 1993 Secretary General Report, supra note 140, at 5.

360. See Protocol I, supra note 8, art. 35, para. 1 ("In any armed conflict, the right of the Parties to the conflict to choose methods or means of warfare is not unlimited.").

361. See id. art. 35, para. 2 ("It is prohibited to employ weapons, projectiles and material and methods of warfare of a nature to cause superfluous injury or unnecessary suffering.").

362. See id. art. 51, para. 4. The article states that

indiscriminate attacks are prohibited. Indiscriminate attacks are:

(a) those which are not directed at a specific military objective;

(b) those which employ a method or means of combat which cannot be directed at a specific military objective; or

(c) those which employ a method or means of combat which cannot be limited as required by this Protocol; and consequently, in each case, are of a nature to strike military Id.

objectives and civilians or civilian objects without distinction.

363. See id. art. 51, para. 5 (" $[\mathrm{A}] \mathrm{n}$ attack which may be expected to cause incidental loss of civilian life, injury to civilians, damage to civilian objects, or a combination thereof, which would be excessive in relation to the concrete and direct military advantage anticipated" is one type of indiscriminate attack).

364. See id. art. 57, para. 2(b) ("[A]n attack shall be canceled or suspended if it becomes apparent that the objective is not a military one or is subject to special protection or that the attack may be expected to cause incidental loss of civilian life, injury to civilians, damage to civilian objects, or a combination thereof, which would be excessive in relation to the concrete and direct military advantage anticipated.").

365. See id. art. 48 ("In order to ensure respect for and protection of the civilian population and civilian objects, the Parties to the conflict shall at all times distinguish between the civilian population and combatants and between civilian objects and military objectives and accordingly shall direct their operations only against military objectives."). 
$52,{ }^{366}$ for example, is a basic step both in military necessity or proportionality analysis and in assessing discrimination (humanity) requirements. Of course, the Martens Clause of article 1 provides protection even beyond the specific safeguards enunciated in the Protocol. ${ }^{367}$

However, Protocol I stretches the envelope of environmental protection much further than mere codification of preexisting norms. Under article 54(2), for example,

[i]t is prohibited to attack, destroy, remove or render useless objects indispensable to the survival of the civilian population, such as food-stuffs, agricultural areas for the production of food-stuffs, crops, livestock, drinking water installations and supplies and irrigation works, for the specific purpose of denying them for their sustenance value to the civilian population or to the adverse Party, whatever the motive, whether in order to starve out civilians, to cause them to move away, or for any other motive. ${ }^{368}$

As the provision's examples illustrate, in many cases it is the environment itself that provides the objects necessary for survival. It must also be noted that the list is not exhaustive. Other items such as fuel oil, electricity, or lines of communication could, depending on circumstances, also merit protection, as long as the attack on them is for the purpose of denying sustenance. Their destruction (absent the article 54(2) safeguards) certainly could have environmental consequences. Under paragraph (2), protected objects are immune from targeting even if the reason for denying sustenance is to secure a military advantage. This is so regardless of whether the intent is to deny sustenance to the civilian population or to the "adverse party," i.e., enemy forces. Exceptions arise only when the protected objects are (1) used solely for the armed forces; (2) not used as sustenance, and destruction will not deprive the civilian population of food or water; or (3) required in the defense of, and executed on, one's own territory. ${ }^{369}$ This essentially. outlaws the scorched-earth tactics used during the Second World War with such tragic consequences for both humans and their environment. Of particular importance is the fact that military necessity has been completely removed from the equation, although the requirement of intent to deny sustenance will limit the reach of article 54(2) somewhat. Finally, the article would preclude

366. See id. art. 52, para. 2. Article 52(2) provides:

Attacks shall be limited strictly to military objectives. In so far as objects are concerned, military objectives are limited to those objects which by their nature, location, purpose or use make an effective contribution to military action and whose total or partial destruction, capture Id. or neutralization, in the circumstances ruling at the time, offers a definite military advantage.

367. See id. art. 1, para. 2 ("In cases not covered by this Protocol or by other international agreements, civilians and combatants remain under the protection and authority of the principles of international law derived from established custom, from the principles of humanity and from the dictates of public conscience.").

368. See id. art. 54, para. 2.

369. See id. art. 54, paras. 3, 5. Anthony Leibler has suggested that since the provision is limited to destruction intended to deny civilians sustenance, and other actions are not treated as prohibited, "at least from the perspective of environmental protection Article 54 is of negligible utility." Leibler, supra note 185, at 107. On the contrary, article 54 may limit efforts to foment unrest among a population, destroy sustenance available to an advancing force that lives largely off the land, or even foul desalination plants on which both civilians and the military rely. 
use of the environment as a weapon if the prohibited effect might result. ${ }^{370}$

While article 54(2) has not proven controversial, another provision with significant environmental consequences, article 56, has. It prohibits attacking dams, dikes, and nuclear electrical power generating stations if the release of "dangerous forces and consequent severe losses among the civilian population" might result. ${ }^{371}$ This clearly anthropocentric prohibition applies even if the facility is a valid military objective. It also includes attacks on any surrounding military objective that might result in the release of dangerous forces. For dams and dikes, the protection is forfeited if they are used for purposes other than their normal functions and "in regular, significant and direct support of military operations and such attack is the only feasible way to terminate such support." ${ }^{372}$ As to nuclear electrical generating stations, attack is permissible only when the facility provides power "in regular, significant and direct support of military operations" and the only way to cut off that support is through attack. ${ }^{373}$ Parties are permitted to arm the facilities, though any armament is limited to defensive use and cannot exceed that necessary to repel hostile action..$^{374}$

Assertions have been made that the article, if given a liberal interpretation, would extend protection to any facility containing "dangerous forces," in particular oil wells or tanks. These assertions are unconvincing. The question whether the list provided should be exhaustive or illustrative surfaced during the drafting process. It was decided that to permit specificity regarding those facilities about which the drafters were most concerned (dams, dikes, and nuclear power facilities), the list would be exhaustive. ${ }^{375}$

Despite limitation in scope, the degree of protection is consequential. First, though the term "severe" appears to mandate a high degree of loss before protections come into effect, that is not the case, for in the official ICRC Commentary the term is clarified as meaning "important" or "heavy." ${ }^{376}$ Conceptually, then, it may be easier to think of the provision as excluding losses that are "unimportant" or "light." Assuming this is a fair characterization rather than merely semantic gymnastics, the quantum of damage necessary to activate article 56 would not be difficult to reach. Furthermore, an attack need not even be certain to result in a release; instead, the criterion is "may cause." Whether an attack may result in a release is a much less subjective determination than whether it will do so.

The robustness of the protection is also apparent in the hurdles to be

370. See Protocol I, supra note 8, art. 54, para. 2. For instance, altering weather or climate could severely affect food production.

371. Protocol I, supra note 8, art. 56, para. 1.

372. Id. art. 56, para. 2(a).

373. Id. art. 56, para. 2(b).

374. See id. art. 56 , para. 5 .

375. See 15 O.R., supra note 323, para. 326. See also BoTHE ET AL., supra note 345, at 352. The Greenpeace Study's statement that "[i]t is unclear whether oil wells constitute installations containing 'dangerous forces.' The examples given in Protocol I . . . are not meant to be exhaustive, and a liberal construction could say that the release of the force of the oil fires and spills is covered," GREENPEACE STUDY, supra note 69 , at 140 , is thus incorrect.

376. ICRC COMMENTARY, supra note 17, para. 2154 (" [A]s so often in this Chapter, this concept is a matter of common sense and it must be applied in good faith on the basis of objective elements such as proximity of inhabited areas, the density of population, the lie of the land, etc."). 
overcome before attack is permitted. Dams and dikes must be used for other than their intended purposes and their support of the enemy effort must be regular, significant, and direct and attacking them must be the only option. Nuclear generating stations enjoy similar safeguards, though they need not be used for other than their normal function. ${ }^{377}$ Notice that virtually all the criteria are stated in the conjunctive. Therefore, even when support is direct and substantial and attack is the only option, if the support is irregular the facility enjoys immunity. The requirement to eliminate feasible alternatives further complicates matters. Once it is determined that there is no other choice, must the weapon that best avoids damage be selected? Normally, the law of armed conflict does not dictate the use of specific tactics, e.g., the use of smart weapons. However, given the heightened protection afforded to these facilities, as well as the requirement to select alternative courses, it would make sense that weapons choice criteria would apply. The Rapporteur acknowledged as much by suggesting that the capabilities of modern weapons heightened the protection afforded under the provision. ${ }^{378}$

Other indications of stringency are found in the intent underlying the relevant verbiage, intent that may suggest, as was the case with "severe," a meaning that differs from common usage. Resort to the ICRC Commentary again illustrates the extent of the protection afforded. It offers two examples: a dike forming part of a system of fortifications and a road across a dam that can be used as an essential route for the movement of armed forces. Even in these circumstances, the regular, significant, and direct criteria apply, thereby indicating that there are times when they might not be met. ${ }^{379}$ The ICRC Commentary then goes on to dismiss criticisms of the standard's apparent subjectivity by noting that the "terms merely express common sense, i.e., their meaning is fairly clear to everyone"; therefore, they simply "need to be interpreted in good faith on the basis of objective elements." 380

At this point, it might seem a daunting task to identify examples of support for military operations that would allow exclusion from the broader protection. In fact, it may be easier than it seems at first glance. Lest those who apply the standard not possess the perceptive abilities to discern what is "fairly clear to everyone," the commentary defines the terms, using the technique of semantic inversion employed above to illustrate "severe." "Regular" implies a time standard and is said not to be "accidental or sporadic." "Significant," according to the commentary, is less precise than regular, but implies support that is more than "negligible" or "merely an incidental circumstance." "Direct" means "not in an intermediate or roundabout way." 381 These definitions actually appear to set a lower

377. See Protocol I, supra note 8, art. 56, para. 2(b). The issue of targeting nuclear facilities was raised at the 1990 Review Conference for the Nuclear Non-Proliferation Treaty. The Hungarian and Dutch delegates, with support from several other delegations, suggested an international agreement to address the topic. The U.S. delegation did not respond to the proposal. See David Fischer \& Harald Müller, The Fourth Review of the Non-Proliferation Treaty, 1991 STOCKHOLM INT'L PEACE RES. INST. Y.B. 555, 566.

378. See 15 O.R., supra note 323 , at 284.

379. See ICRC COMMENTARY, supra note 17 , para. 2162 , at 671 .

380. Id.

381. Id. 
standard of protection than would result from reference to common American usage of the terms.

The United States opposes article 56 as excessively restrictive, pointing to the protections already provided to the civilian population by the principle of proportionality. From the U.S. perspective, setting the threshold for attack so high invites the enemy to use protected facilities for military purposes. If the attacker decides that the criteria are not met, he will refrain from attack. On the other hand, if he decides that the criteria have been met, he opens himself up to condemnation by those who would disagree with his assessment. Given the multiplicity of criteria and their inherent subjectivity, it would be very difficult to cite an action that would be objectively permissible. Finally, critics argue that the protection for nuclear electrical power generation facilities ignores the existence of integrated power grids, an argument contradicted by the ICRC Commentary. 382

Advocates of the prohibition would reply by pointing to the requirement that the resultant losses among the civilian population be "severe." Therefore, only attacks with dramatic consequences are forbidden. Furthermore, since severity of loss is a prerequisite to protection, in most cases simple proportionality analysis will preclude those attacks that the article's opponents might complain of being prohibited from conducting. It is hard to imagine an attack with severe civilian losses that would be proportional if its contribution to the enemy's military effort were not regular, significant, and direct. From this perspective, article 56 essentially operates to resolve gray area situations in favor of the civilian population.

There is little doubt that adherence to article 56 would heighten protection of the environment during warfare. Though proportionality analysis would provide similar levels of protection in most cases, article 56's greater specificity serves as a restraint on self-serving interpretations of proportionality by the malevolent. This does not answer the question whether Protocol I is worthy of ratification, or even whether article 56 is an overall step forward in the law of war. Yet because it is less susceptible to avoidance through interpretation, from an environmental perspective it represents progress.

As a final aside, it bears mentioning that U.S. aircraft attacked nuclear facilities during the Gulf War. However, article 56 was not applicable because the United States was not a Protocol I party and because it would be difficult to make a case that the provision represented customary international law. Furthermore, the targets were not nuclear electrical generating stations. Some may argue about whether the attacks "may" have resulted in a release, or even whether the United States took all "practical precautions" to avoid causing one, but ultimately the missions did not implicate Protocol $1 .{ }^{384}$

382. See DEPLOYMENT DESKBOOK, supra note 318, tab 12, para. 1.8.7.1; ICRC COMMENTARY, supra note 17 , paras. 2164-66, at 671-72.

383. Ambassador Aldrich, who negotiated Protocol I for the U.S., provides the core analysis supporting ratification. See Aldrich, supra note 50, at 714-16.

384. See Jozef Goldblat, Legal Protection of the Environment Against the Effects of Military Activities, 22 Bull. PEACE PROPOSALs 399, 400-01 (1991). Professor Goldblat takes a fairly critical approach to the topic, using as an example the 1981 bombing of the Iraqi nuclear reactor by the Israelis. 
Like Geneva Convention IV, Protocol I provides for grave breaches. Neither of the environmental provisions to be discussed in greater detail below, articles 35(3) and 55, is included in the category. Nevertheless, the causation of environmental damage could, under specific circumstances, constitute a grave breach (war crime) if the act in question were willful and death or serious bodily injury would result. These include making the civilian population the object of attack, launching an indiscriminate attack against civilians or civilian objects, and striking works or installations containing dangerous forces knowing that the harm caused will be excessive. ${ }^{385}$ In such cases, damage to the environment may be collateral or the environment might be attacked for the purpose of causing the requisite result. As war crimes constituting grave breaches, such acts would require the state in which the offender is found to prosecute him or cooperate in his extradition. ${ }^{386}$ The mere fact that an offense is not a grave breach, however, does not preclude prosecution; it only means that the heightened enforcement regime set forth for grave breaches does not apply.

Finally, one notable limitation of the Protocol is that its articles regarding protection of the civilian population and civilian objects (arts. 48-67) are not generally applicable to naval warfare or aerial combat. ${ }^{387}$ What is interesting is that this restriction affects all of the significant provisions relevant to the environment that will be discussed except article 35(3). This is due to the placement of article 35(3) in an earlier section on methods and means of warfare. As a result, the scope of article 35(3) will be broader than that of its counterpart, article 55, even though their text is nearly identical. This is especially significant in light of the fact that the former adopts an intrinsic value approach, ${ }^{388}$ whereas the latter is anthropocentric in nature.

385. See Protocol I, supra note 8 , art. 85 , para. 3(a)-(c).

386. See id. art. 88 .

387. See id. art. 49 , para. 3. Article 49 (3) provides:

The provisions of this Section [Civilian Population] apply to any land, air, or sea warfare which may affect the civilian population, individual civilians or civilian objects on land. They further apply to all attacks from the sea or from the air against objectives on land but do not otherwise affect the rules of international law applicable in armed conflict at sea or in the air.

Id. The exclusion resulted from a conscious effort by the delegates of the Diplomatic Conference to secure agreement where it was most likely to come-in the "well-established" body of law governing land warfare. Their concern was that naval warfare had fundamentally changed, thereby becoming unsettled, during and after the Second World War. In particular, differences of opinion over the state of the law governing issues such as visit and search, the legality of attacks on merchant vessels, and submarine warfare were felt likely to impede the process of updating the existing Geneva Conventions. See BOTHE ET AL., supra note 345, at 290; ICRC COMMENTARY, supra note 17, at 606 . The Bothe commentary notes that this approach was ICRC-proposed and had the support of the states with the largest navies. These parties believed it would be counterproductive to pursue revision of the law of naval warfare at the time, particularly as the preparatory work of the experts had not focused on the subject. See BOTHE ET AL., supra note 345 , at 290 .

Similarly, the laws of aerial warfare are not formally codified, and the customary law that addresses the topic is ambiguous. Therefore, the delegates decided to make Protocol I inapplicable at sea or in the air unless the attack in question targeted land objectives. See Protocol I, supra note 8, art. 49, para. 3. It has been suggested that one additional exception is the extension of applicability to attacks from the sea or air against targets in the territorial sea. See Walker, supra note 52, at 122 . This reasonable approach is based on the Protocol's use of "territory" and "national territory," terms which in their legal context include the territorial sea.

388. See supra notes 323-31 and accompanying text. 


\section{ENMOD}

The final core prescriptive instrument relevant to the environment in the jus in bello is ENMOD. Negotiated contemporaneously with Protocol I and ratified by the United States in 1980 , it was in part a reaction to the environmental modification techniques practiced during the Vietnam War, such as attempts to alter weather. ${ }^{389}$ Though the Soviet Union was the first to propose a limitation on environmental modification, the United States quickly became a prime mover behind the Convention. ${ }^{390}$ In fact, the United States already had renounced the use of climate modification techniques in 1972 as a matter of policy. ${ }^{391}$ As of April 1996, there were sixty-four parties to the Convention, including most major states (e.g., the United States, Russia, Germany, and Japan). Countries that have signed but not ratified it include Iraq, Iran, and Syria, whereas two significant holdouts are France and China. ${ }^{392}$

ENMOD is "Hague Law" in that it limits methods and means of warfare. It is not necessary that those methods and means actually affect the environment, for the only prohibition is on use of the environment as a weapon. ${ }^{393}$ Article I provides:

(1) Each State Party to this Convention undertakes not to engage in military or any other hostile use of environmental modification techniques having widespread, long-lasting or severe effects as the means of destruction, damage or injury to any other State Party.

(2) Each State Party to this Convention undertakes not to assist, encourage or induce any State, group of States or international organization to engage in activities contrary to the provisions of paragraph 1 of this article..$^{394}$

Though the "widespread, long-lasting or severe" formula resembles that found in Protocol I, here it is stated in the alternative, using "or." Since a technique meeting any of the threshold criteria will be prohibited, the result is a much more stringent standard of protection than that found in Protocol I.

An effort was made during the ENMOD drafting process to clarify

389. See Hearings to Hear Testimony on the Convention on the Prohibition of Military or Any Other Hostile Use of Environmental Modification Techniques Before the Senate Comm. on Foreign Relations, 96th Cong. (1979); Environmental Modification Treaty: Hearings on the Convention on the Prohibition of Military or Any Other Hostile Use of Environmental Modification Techniques Before the Senate Comm. on Foreign Relations, 95th Cong. (1978).

390. See THE LAwS OF ARMED CONFLICTS, supra note 153, at 163. In 1974 the Soviet Union submitted a draft convention to the General Assembly, which in turn referred it to the Conference of the Committee on Disarmament. At that point the United States and the Soviet Union provided the Conference with identical drafts of a proposed convention. The text was revised in committee and submitted to the General Assembly, which approved it on December 10, 1976. The Convention was then opened for signature. It entered into force on October 5, 1978. See id.

391. See Terry, supra note 92, at 64 . Also recall the sense of the Senate Resolution. See supra notes 32-33 and accompanying text.

392. A list of current parties is maintained at net site: <http://www.un.org/Depts/Treaty > . Note that a state that has signed but not ratified a convention is obligated not to take actions contrary to the object and purpose of the agreement, at least until it has made clear its intent not to become a party. See Vienna Convention, supra note 193, art. 18.

393. This distinction motivated the name change in the Jordanian Note Verbale. See supra notes 115-16 and accompanying text.

394. ENMOD, supra note 34 , art. I. 
terminology. In the Understanding Relating to Article I, "widespread" was defined as "encompassing an area on the scale of several hundred kilometres"; "long-lasting" as "lasting for a period of months, or approximately a season"; and "severe" as "involving serious or significant disruption or harm to human life, natural and economic resources or other assets." 395 Again, this constitutes a higher standard than that found in Protocol I, particularly when comparing the definition of "long-lasting" as seasonal with the commonly accepted understanding of the Protocol I limit as being measured in decades. Similarly, describing "severe" as "serious or significant" also serves to heighten protection, as does the use of "disruption" instead of "damage" in setting forth the requisite violative effect. This attempt to define the core verbiage of the prescription was not universally accepted, though the vast majority of the parties have effectively accepted it by not filing reservations (interpretive statements) related to the definitional issues. ${ }^{396}$

One source of confusion may be differences in opinion regarding whether to use individual or cumulative effect in assessing the damage. This is an important issue in the Protocol I context as well. For instance, the United States has reportedly stated that the use of herbicides to modify the environment would not be forbidden unless the end result of an individual use were widespread, long-lasting, or severe destruction. ${ }^{397}$ As one commentator notes, "[i]t follows that, as the consequences of an individual mission would probably fall below these thresholds, such missions would not be prohibited, despite the fact that overall the damage would clearly fall well outside allowed limits." 398

This assertion is certainly incorrect in the context of current understandings. Consider the most vivid example of environmental damage during hostilities in recent times, the intentional Gulf War oil spills. Virtually no one asserted that each Iraqi spill should be considered individually in assessing legality. On the contrary, commentators were unanimous in citing the releases as a single operation despite the fact that the spills were separated in time and executed in differing ways (release from oil terminals, ships, etc.). Though this example is not an ENMOD scenario, it illustrates the international community's attitude towards severability. What it did distinguish were the spills from the fires.

The best approach acknowledges, on the one hand, the inappropriateness

395. Understanding Relating to Article 1 , Report of the Conference of the Committee on Disarmament, U.N.GAOR, 31st Sess., Supp. No. 27, at 91-92, U.N. Doc. A/31/27 (1976), reprinted in THE LAWS OF ARMED CONFLICTS, supra note 153, at 168. There were four Understandings which, though not part of the Convention, were included in the report transmitted by the Conference of the Committee on Disarmament to the United Nations General Assembly.

396. Turkey, however, filed an interpretive understanding stating that in its opinion the "terms 'widespread,' 'long-lasting' and 'severe effects' . . . need to be clarified. So long as this clarification is not made the Government of Turkey will be compelled to interpret itself the terms in question and consequently it reserves the right to do so as and when required." Turkish Interpretive Statement Filed at Time of Signature, May 18, 1977, reprinted in Multilateral Treaties Deposited with the Secretary General (visited Oct. 23, 1996) < http://www.un.org/Depts/Treaty>.

397. See Jozef Goldblat, The Environmental Modification Convention of 1977: An Analysis, in ENVIRONMENTAL WARFARE: A TEChNICAL, LEGAL AND POLICY APPRAISAL 53, 55 (Arthur Westing ed., 1984).

398. Carruthers, supra note 25 , at 47. 
of simply lumping all wartime environmental damage together to determine whether the article I thresholds are met. This is so if only because an actor is unlikely to have been able to anticipate reasonably what the net results of his many environmentally destructive actions would be; it would be difficult to demonstrate even a "should have known," let alone a "knew," level of scienter. On the other hand, it would be even more absurd to excuse conduct because the ultimate damage resulted from multiple actions, such as aerial flights, none of which alone caused the requisite level of destruction. Instead, it should be asked whether the actions are part of a single integrated plan or operation designed to achieve a common, or closely related, result. By using an intent element as the connective variable, scienter problems (at least those involving scope of the relationship) are rendered de minimis.

Definitional issues also pervade article II's use of the phrase "environmental modification technique" as "any technique for changing-through deliberate manipulation of natural processes-the dynamics, composition or structure of the earth, including its biota, lithosphere, hydrosphere and atmosphere, or of outer space." ${ }^{399}$ Illustrative examples cited in the Understanding relating to article II include earthquakes, tsunamis, an upset in the ecological balance of a region, changes in weather patterns, changes in climate patterns, changes in the state of the ozone layer, and changes in the state of the ionosphere. ${ }^{400}$ The Understanding indicates that while these are only examples, their use would create the presumption of a violation.

What stands out in the definition is its limitation to techniques that involve manipulation of natural processes. There is relative consensus, for instance, that the techniques employed by Iraq during the Gulf War did not implicate ENMOD prohibitions, and would not have done so even had Iraq been a party. ${ }^{401}$ While the environment may have been the target, it was not the weapon. Therefore, despite a very restrictive standard, the narrow range of techniques contemplated in ENMOD suggests that, given current technologies, the Convention will be of limited value. Probably its greatest impact will be

399. ENMOD, supra note 34, art. II.

400. See Understanding Relating to Article II, Report of the Conference of the Committee on Disarmament, U.N.GAOR, 31st Sess., Supp. No. 27, at 91-92, U.N. Doc. A/31/27 (1976), reprinted in THE LAWS OF ARMED CONFLICTS, supra note 153, at 168. The Understanding reads as follows:

It is further understood that all the phenomena listed above, when produced by military or any other hostile use of environmental modification techniques, would result, or could reasonably be expected to result, in widespread, longlasting or severe destruction, damage or injury. Thus, military or any other hostile use of environmental modification techniques as defined in article II, so as to cause those phenomena as a means of destruction, damage or injury to another State Party, would be prohibited.

It is recognized, moreover, that the list of examples set out above is not exhaustive. Other phenomena which could result from the use of environmental modification techniques as defined in article II could also be appropriately included. The absence of such phenomena from the list does not in any way imply that the undertaking contained in article I would not Id. be applicable to those phenomena, provided the criteria set out in that article were met.

401. The DOD report cited with approval the conclusions of the Ottawa Conference on this point. See DOD REPORT, supra note 69, at 0-26 to 0-27. However, the Commission for International Due Process of Law, in its draft indictment of Saddam Hussein and his advisers, did allege an ENMOD violation. See Kutner \& Nanda, supra note 301, at 95. 
directional, by foreclosing weapons development along the prohibited lines.

The future effectiveness of ENMOD may be further limited by its enforcement regime. It is a regime based exclusively on state responsibility, possibly because the greater part of the Convention is focused on peacetime activities. The result is an essentially political system for assuring compliance. ${ }^{402}$ In situations preliminary to armed conflict, or in armed conflict itself, the primary remedy is referral to the Security Council for enforcement action. However, the Security Council already is empowered under the Charter to take appropriate actions in response to most potential breaches of ENMOD; the Convention's enforcement provisions add little new power. Further limiting the enforcement regime's effectiveness is the fact that the Convention's scope is limited to damage caused to parties. ${ }^{403}$

How should ENMOD be assessed overall? ${ }^{404}$ Most importantly, ENMOD affects only a very narrow band of possible operations, many of which have not advanced beyond the concept stage. ${ }^{405}$ Furthermore, it has not attained the wide acceptance that Protocol I enjoys, a particularly unfortunate state of affairs given its limitation to the territory of parties. Finally, ENMOD is another example of an absolute prohibition in that no military necessity or proportionality balancing is required prior to its taking effect. This poses the same risk discussed with regard to Protocol I-that human values might suffer for environmental ends. Of course, the fact that the requisite damage need not be to the environment of another party suggests that the prohibition is framed in essentially anthropocentric terms. To some extent, this will mitigate the danger of not factoring in proportionality and necessity. Whether the gains represented by ENMOD merit this risk is a fair matter for debate. Regardless of the answer, ENMOD is finding its way into the documents that underlie development of the operational code-law of war manuals. ${ }^{406}$

\section{Miscellaneous Prescriptions}

Though the four conventions addressed above represent the core environmental prescriptions in the jus in bello, others also contain provisions that enhance protection of the environment during hostilities. Among the most

402. See ENMOD, supra note 34, art. V.

403. See id. art. I, para. 1 ("Each State Party to this Convention undertakes not to engage in military or any other hostile use of environmental modification techniques having widespread, long-lasting or severe effects as the means of destruction, damage or injury to any other State Party.") (emphasis added).

404. The ENMOD Convention provided for review conferences to assess the provisions and compliance therewith. See ENMOD, supra note 34, art. VIII. Neither the first conference in 1984 nor the second in 1992 was able to arrive at a consensus on anything significant. The second, however, did reaffirm the need to conduct further reviews. See Dieter Fleck, Legal and Policy Perspectives, in EFFECTING COMPLIANCE 155-56 (Hazel Fox \& Michael A. Meyer eds., 1993).

405. One such concept involves melting the Arctic ice cover in order to raise the level of the sea and thereby flood coastal areas. See Hans Blix, Arms Control Treaties Aimed at Reducing the Military Impact on the Environment, in ESSAYS IN INTERNATIONAL LAW IN HONOUR OF JUDGE MANFRED LACHS 703, 709 (Jerzy Makarczyk ed., 1984).

406. See, e.g., GERMAN MANUAL, supra note 168, para. 403 (distinguishing Protocol I from ENMOD damage). 
important are the 1925 Gas Protocol, ${ }^{407}$ the 1993 Chemical Weapons Convention, ${ }^{408}$ and the United Nations Conventional Weapons Convention. ${ }^{409}$ It is instructive to mention each briefly. ${ }^{410}$

The United States ratified the first of these, the 1925 Gas Protocol, in 1972. The Protocol prohibits the use of "asphyxiating, poisonous, or other gases, and of analogous liquids, materials, and devices." ${ }^{411}$ Extending to both chemical and biological agents, the treaty is widely held to be declaratory of customary international law. In terms of environmental protection, the prohibitions are significant, especially in light of the fact that chemicals can be transferred through the food chain.

Unfortunately, there is significant controversy over the scope of the Convention, a point that should be obvious from the half-century that it took the United States to become a party. Even when it did ratify, the United States included a first-use reservation-a statement that it would not be bound by the prohibitions if the other side in a conflict violated the agreement first. ${ }^{412}$ Executive Order 11,850 implements the agreement with respect to the wartime use of chemical herbicides and riot control agents. ${ }^{413}$ Setting forth U.S. policy, it retains the option of retaliation, but renounces the use of herbicides. Executive Order 11,850 goes on to cite explicitly two circumstances in which the use of herbicides is authorized even absent formal authorization-domestic employment and use to clear vegetation around the "immediate defensive perimeter" surrounding U.S. bases. ${ }^{414}$

Other states also have adopted first-use reservations, ${ }^{415}$ thereby creating two distinct treaty regimes. The exclusion of herbicides, however, is not widespread; a number of close allies have interpreted the prohibition as extending to all gases. ${ }^{416} \mathrm{In}$ fact, during the Vietnam War, the U.N. General Assembly issued a resolution in response to U.S. use of herbicides that purported to clarify the scope of the Protocol. The resolution stated that the Protocol prohibited use of:

(a) [a]ny chemical agents of warfare-chemical substances, whether gaseous, liquid or

407. Gas Protocol, supra note 132.

408. Chemical Weapons Convention, supra note 135.

409. Conventional Weapons Convention, supra note 134.

410. Three other conventions cited in the 1993 Secretary General Report that also have some marginal environmental effect are the Biological Weapons Convention, supra note 133; the Convention for the Protection of Cultural Property, supra note 153; and the Convention for the Protection of the World Cultural and Natural Heritage, Nov. 16, 1972, 1037 U.N.T.S. 151.

411. Gas Protocol, supra note 132, pmbl.

412. The "Protocol shall cease to be binding on the government of the United States with respect to the use in war of asphyxiating, poisonous or other gases, and of all analogous liquids, materials, or devices, in regard to an enemy State if such State or any of its allies fails to respect the prohibitions laid down in the Protocol." Reservation Made on Ratification, reprinted in THE LAWS OF ARMED CONFLICTS, supra note 153 , at 126.

413. See Exec. Order No. 11,850, 40 Fed. Reg. 16,187 (1975).

414. See id.

415. These include France, Iraq, Israel, Libya, the former Soviet Union, and the United Kingdom. For the text of the reservations, see THE LAWS OF ARMED CONFLICTS, supra note 153, at 121-27.

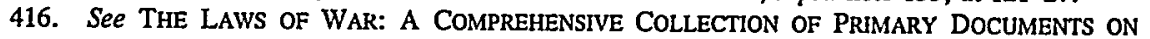
INTERNATIONAL LAWS GOVERNING ARMED CONFLICT 58 (W. Michael Reisman \& Chris Antoniou eds., 1994). 
solid-which might be employed because of their direct toxic effect on man, animals or plants;

(b) [a]ny biological agents of warfare-living organisms, whatever their nature, or infective material derived from them-which are intended to cause disease or death in man, animals, or plants, and which depend for their effect on their ability to multiply in the person, animal or plant attacked. ${ }^{417}$

Nevertheless, the issue of scope remains alive today, with lack of unanimity continuing to weaken the overall regime. ${ }^{418}$

A related convention is the Chemical Weapons Convention of 1993. The war between Iran and Iraq, in a fashion reminiscent of the First World War, drew attention to the horrors of chemical weapons when they were used both during military campaigns and against the Iraqi Kurds. As a result of these tragedies, the Conference on the Prohibition of Chemical Weapons adopted the Declaration on the Prohibition of Chemical Weapons in January 1989.419 Signatories of the Declaration condemned the states that had employed chemical weapons and renounced their use. They also reaffirmed their commitment to the 1925 Gas Protocol prohibitions and urged nonparties to accede to the agreement. ${ }^{420}$

Concerted efforts to secure a robust chemical weapons convention followed the Conference. Those efforts came to fruition in 1993. As of April 1996, the Chemical Weapons Convention has 160 signatories, including the United States. Of the 160 signatories, forty-nine have become parties. ${ }^{421}$ It was transmitted to the Senate for ratification in November 1993. The treaty remains open for signature and will come into force in accordance with its terms 180 days after deposit of the sixty-fifth instrument of ratification. ${ }^{422}$

Under the Convention, parties bind themselves not to use, under any circumstances, chemical weapons, or to "develop, produce, otherwise acquire, stockpile or retain chemical weapons, or transfer, directly or indirectly, chemical weapons to anyone." ${ }^{223}$ The preamble emphasizes that this

417. G.A. Res. 2603, U.N. GAOR, 24th Sess., Supp. No. 30, at 16, U.N. Doc. A/7630 (1969).

418. For example, Professor Verwey has noted:

The better view appears to be ... that this Protocol was never intended to protect the environment, and that even the employment of herbicides and defoliant agents of the types used during the Vietnam War would only be prohibited to the extent that they can be proven to be toxic to human beings and to actually cause human casualties.

Verwey, Additional Rules, supra note 13, at 5. On the other hand, Professor Goldblat states that the Protocol "is widely interpreted as applying not only to humans and animals, but also to plants. This is now recognized also by the United States, which made extensive use of herbicides during the war in Vietnam." Goldblat, supra note 384 , at 403 . In fact, most states do see the Protocol as extending to plants, and though the United States does not, it has renounced the use of herbicides as a matter of policy except in certain circumstances. See supra notes 413-14 and accompanying text.

419. Final Declaration of the Conference of the States Parties to the 1925 Geneva Protocol and Other Interested States on the Prohibition of Chemical Weapons, Jan. 11, 1989, 28 I.L.M. 1020.

420. See id.

421. See Multilateral Treaties Deposited with the Secretary General (visited Oct. 23, 1996) <http://www.un.org/Depts/Treaty>.

422. See Chemical Weapons Convention, supra note 135, art. XXI. For an excellent summary of the Convention, as well as the history leading up to its completion, see The Chemical Weapons Convention (visited Oct. 23, 1996) <http://www.opcw.nl/guide.htm>.

423. Chemical Weapons Convention, supra note 135, art. I, para. 1(a). The Convention is not subject to reservation. See id. art. XXII. 
prohibition is complementary to, not in lieu of, the 1925 Gas Protocol. ${ }^{424}$ It also addresses several issues that have generated controversy regarding the latter agreement. For instance, it rules out retaliation with chemicals and, by characterizing them as such, settles much of the debate over whether herbicides are chemicals. ${ }^{425}$

An important feature of the Convention is its description of its prohibitions in terms of means or methods of warfare. ${ }^{426}$ This raises the question whether use in situations such as in extremis hostage rescue or riot control during civil affairs operations is permissible. The position of the Army is that the Convention is inapplicable in MOOTW because they are operations "conducted for peaceful purposes and do not constitute armed conflict." Lest this position be characterized as an excessively liberal interpretation, it must be remembered that Executive Order 11,850 restrictions remain intact during MOOTW. ${ }^{428}$

The last of the three agreements is the United Nations Conventional Weapons Convention. Like Protocol I and ENMOD, this agreement specifically addresses the environment, but does so in a slightly different fashion. Protocol I discusses use of weapons, but not weapons themselves. ENMOD also fails to discuss weapons themselves, for it is concerned with the use of the environment as a weapon through the manipulation of natural processes. The Conventional Weapons Convention begins to fill the gap by focusing on specific conventional weapons, some of which are capable of harming the environment.

The agreement begins somewhat controversially. After reiterating the customary international law principle of humanity, ${ }^{429}$ it restates the provisions of article 35(3) of Protocol I. ${ }^{430}$ This led France and the United States to attach reservations (the United States referred to its reservations as understandings) to their instruments of ratification indicating that the preamble

424. See id. pmbl.

425. See id. art. II, para. 2. The Convention defines "toxic chemical" as

any chemical which through its chemical action on life processes can cause death, temporary incapacitation or permanent harm to humans or animals. This includes all such chemicals, regardless of their origin or of their method of production, and regardless of whether they are Id. produced in facilities, in munitions or elsewhere.

426. For example, in setting forth uses of chemicals that are not prohibited, the Convention includes "[m]ilitary purposes not connected with the use of chemical weapons and not dependent on the use of the toxic properties of chemicals as a method of warfare." Id. art. II, para. 9(c).

427. OPERATIONAL LAW HANDBOOK, supra note 179, at 5-5.

428. While the Army's approach makes sense, where does its outer limit lie? For instance, would Saddam Hussein's actions against Iraqi Kurds be covered? That would depend on whether the operations were characterized as "armed conflict." The best interpretation is that use is forbidden in situations amounting either to international (Protocol I) or noninternational (Protocol II) "armed conflict." See supra note 10 (distinguishing between international and noninternational armed conflict).

429. See Conventional Weapons Convention, supra note 134, pmbl. ("Basing themselves on the principle of international law that the right of the parties to an armed conflict to choose methods or means of warfare is not unlimited, and on the principle that prohibits the employment in armed conflicts of weapons, projectiles and material and methods of warfare of a nature to cause superfluous injury or unnecessary suffering ....").

430. See id. ("Also recalling that it is prohibited to employ methods or means of warfare which are intended, or may be expected, to cause widespread, long-term and severe damage to the natural environment ...."). 
applies only to Protocol I parties. ${ }^{431}$ Issues of applicability aside, the heart of the Convention is found in three attached protocols. ${ }^{432}$ The first, which addresses nondetectable fragments, is not applicable to this study and will not be addressed. ${ }^{433}$ Protocol II covers mines, booby traps, and similar devices. ${ }^{434}$ While mines would be unlikely to cause extensive damage to the environment, they certainly could harm humans and animals, and render areas of land unusable. Protocol II provides environmental protection in two ways. First, a proportionality standard balances damage to civilian objects against direct military advantage. ${ }^{435}$ The Protocol then imposes humanity-based standards by forbidding indiscriminate use, requiring mine locations to be recorded, and permitting the remote delivery of only self-neutralizing mines. ${ }^{436}$ These are classic anthropocentric provisions providing indirect environmental protection.

Direct protection of the environment is found in article 2(4) of the agreement on incendiary weapons, Protocol III, which provides that "[i]t is prohibited to make forests or other kinds of plant cover the object of attack by incendiary weapons except when such natural elements are used to cover, conceal or camouflage combatants or other military objectives, or are themselves military objectives." ${ }^{437}$ The United States has elected not to ratify this Protocol, although its objections are broadly based on the overall utility of incendiaries in situations in which an enemy is dug in well, rather than on the Protocol's environmental protection component.

There is little question that article 2(4) would enhance environmental protection, for incendiary weapons, like forest fires, can have devastating environmental impact. ${ }^{438}$ Animal and plant life is destroyed and habitats

431. The understandings and reservations appear at Multilateral Treaties Deposited with the Secretary General, supra note 421. The U.S. Understanding is as follows: "The United States considers that the fourth paragraph of the preamble to the convention, which refers to the substance of the provisos of article 35(3) and article 55(1) of Additional Protocol I to the Geneva Conventions for the Protection of War Victims of August 12,1949, applies only to States which have accepted those provisions." Id.

432. Addition of a fourth protocol on blinding lasers was approved by the October 1995 Review Conference. See Additional Protocol on Blinding Laser Weapons (Protocol IV) to the Convention on Prohibitions or Restrictions on the Use of Certain Conventional Weapons Which May be Deemed to be Excessively Injurious or to Have Indiscriminate Effects, Oct. 12, 1995, U.N. Doc. CCW/CONF.I/7 (1995).

433. See Protocol on Non-Detectable Fragments (Protocol I), Conventional Weapons Convention, supra note 134.

434. See Protocol on Prohibitions or Restrictions on the Use of Mines, Booby-Traps and Other Devices (Protocol II), Conventional Weapons Convention, supra note 134.

435. See id. art. 3, para. 3(c) (prohibiting states from placing weapons "which may be expected to cause incidental loss of civilian life, injury to civilians, damage to civilian objects, or a combination thereof, which would be excessive in relation to the concrete and direct military advantage anticipated").

436. See id. arts. 3, 5, 7 .

437. Protocol III, supra note 134, art. 2, para. 4.

438. In 1973, the Secretary General of the United Nations noted that

[a]lthough there is a lack of knowledge of the effects of widespread fire in these circumstances, such attempts may lead to irreversible ecological changes having grave longterm consequences out of all proportion to the effects originally sought. This menace, though largely unpredictable in its gravity, is reason for expressing alarm concerning the massive employment of incendiaries against the rural environment.

UNTEd NATIONS DEP'T OF POLITICAL AND SEC. COUNCIL AFFAIRS, NAPALM AND OTHER INCENDIARY Weapons and All AsPects of Their Possible USE, U.N. Doc. A/8803/Rev.1, U.N. Sales No. E.73.I.3 (1973). 
often are irreparably damaged by fire and smoke. At the same time, though, the article allows for necessity by excluding the three most likely military uses of such areas; it acts as a toggle switch for the protections provided. Of course, once the prohibition is "turned off," proportionality analysis is still necessary to determine if the target is indeed legitimate.

Issues of the overall utility of incendiary weapons aside, this general approach may serve as a useful model for future environmental prescriptions. Absolute prohibitions, such as that in article 35(3), risk the possibility of actually increasing the harm caused by not accounting for proportionality or military necessity. On the other hand, simply to cite the principles is to create an exception that swallows the rule. Protocol III mitigates these problems by outlining the actions to which a response is militarily necessary, ${ }^{439}$ thereby opening the door for a subsequent proportionality analysis. Admittedly, any time applicable scenarios are catalogued in law of war instruments, some either slip through the cracks or surface later as warfare evolves. However, it is preferable to address them supplementally than to craft a prescription devoid of substantive effect. Therefore, albeit limited in scope, Protocol III's environmental provision does offer a workable means for protecting one aspect of the environment, and contains the seeds for future environmental law of war efforts.

\section{Responsibility Under the Jus in Bello}

Wartime responsibility is a relatively well settled topic. Generally, a wrong committed during wartime results in liability for consequences arising therefrom. Payment of reparations is the usual remedy. The basic principle was expressed more than half a century ago by the Permanent Court of International Justice in the well known case of The Factory at Chorzów. ${ }^{440}$ There, the court held that "reparation must, as far as possible, wipe out all the consequences of the illegal act and reestablish the situation which would, in all probability, have existed if that act had not been committed." 441 The compensation requirement, including compensation for all wrongful "acts committed by persons forming part of a Party State's armed forces," also is found in Hague IV and Protocol I. ${ }^{442}$ ENMOD contains no liability provision. 443

Interestingly, under Hague IV and Protocol I, responsibility lies for acts by a state's "organs" -including members of its armed forces-even if those acts are ultra vires. ${ }^{444}$ This is not the case under general principles of international law, such as those set forth in the International Law Commission's Draft Articles of State Responsibility. Thus, on the one hand, Hague IV and Protocol I would appear to establish a higher standard of

439. See Protocol III, supra note 134, art. 2, para. 4.

440. Factory at Chorzów (Germ. v. Pol.), 1928 P.C.I.J. (ser. A) No. 17 (Sept. 13).

441. Id. at 47 .

442. See Hague IV, supra note 130, art. 3; Protocol I, supra note 8, art. 91.

443. See ENMOD, supra note 34.

444. See Greenwood, supra note 220 , at 5 (citing decision of arbitral tribunal in United StatesMexican Mixed Claims Commission, Youmans, 4 R.I.A.A. 110 (1926)). 
responsibility for violations of their rules than would otherwise be the case. On the other hand, one might argue that the two instruments merely codify what has become a generally accepted principle of state responsibility during armed conflict. This determination is difficult to make because of international law's limited experience with reparations. Consequently, as Professor Christopher Greenwood has noted, "[o]n the whole . . . State responsibility has not proved a particularly effective means of enforcing the law." 445

Even if reparations were widely imposed, it is unlikely that they would be an effective deterrent to environmental destruction. States that resort to armed force are unlikely to decide to forgo an act because of the pecuniary risk, for the risk only becomes a reality if the state suffers a military defeat. The desire to avoid possible defeat would certainly outweigh any deterrent effect generated by the possibility that the loser might have to make reparations. After all, in the vast majority of cases, the likelihood of defeat will exceed the likelihood of having to pay reparations; states sometimes lose without having to pay reparations, but they almost never make reparations without having lost. This is certain to remain the case, at least until the emergence of a supranational authority with true adjudicative and enforcement powers sufficient to compel a wrongdoing victor to pay.

What the logic demonstrates is that two purposes, retribution and restitution-punishing wrongdoers and making victims whole-are at the core of reparations. If deterrence were the goal, then the imposition of reparations would have to make wrongdoers believe that their misdeeds almost certainly would result in punishment. Reparations, however, are too infrequent to induce this belief. In contrast, both restitution and retribution are more easily balanced by competing interests (e.g., post-hostilities political stability) because they are not generally intended to alter the violator's behavior. Instead, they are victim focused.

It is not the intent here to downplay the role of state responsibility, or the reparations that flow therefrom. That retribution is a valid aim of punishment in the international arena, much as it is in domestic judicial systems, can be argued convincingly. More importantly, reparations contribute to the rebuilding of a global community that has been harmed by a breach of its norms. This perspective makes particular sense in the environmental context because restoration is a costly proposition.

The Gulf War is an excellent case in point. In October 1990, the Security Council passed Resolution 674, which stated that "under international law [raq] is liable for any loss, damage or injury arising in regard to Kuwait and third States, and their nationals and corporations, as a result of the invasion and illegal occupation of Kuwait by Iraq." 446 This was followed in March by Resolution 686, which insisted that Iraq "accept in principle its liability under international law for any loss, damage, or injury" that resulted from its occupation of Kuwait. ${ }^{447}$ As the Gulf War drew to a close, Resolution 687,

445. Id. at 8 .

446. S.C. Res. 674, U.N. SCOR, 45th Sess., 2951st mtg. para. 8, U.N. Doc. S/RES/674 (1990), reprinted in 29 I.L.M. 1561, 1563.

447. S.C. Res. 686, U.N. SCOR, 46th Sess., 2978th mtg. para. 2(b), U.N. Doc. S/RES/686(1991), reprinted in 30 I.L.M. 568, 569. 
the ceasefire resolution passed by the Security Council, plainly stated that Iraq was responsible for the damage caused by its invasion and occupation of Kuwait and called for the establishment of a body to handle claims against Iraq from a fund capitalized by a levy on Iraqi oil exports. ${ }^{448}$ The United Nations Compensation Commission was established by Resolution 692 and is currently involved in the process of receiving claims. ${ }^{449}$ The only money in the fund, however, consists of contributions by several states drawn primarily from frozen Iraqi assets.

By basing liability on Iraq's invasion and illegal occupation of Kuwait rather than an on environment-specific prescription, the Security Council neatly sidestepped the issue of responsibility for violation of the environmental law of war. Specifically, the basis of liability was a violation of article 2(4) of the U.N. Charter, a wrongful resort to force under the jus ad bellum. This facilitates the making of claims because framing them in this fashion avoids various technical legal issues involving party status, interpretation of treaty text, the content of customary international law, etc. Essentially, the inquiry is reduced to two issues of fact: causation and damage. Environmental damage is merely one of many forms of compensable damage. ${ }^{450}$ This approach

448. See S.C. Res. 687, U.N. SCOR, 46th Sess., 2981st mtg. paras. 16-19, U.N. Doc. S/RES/687 (1991), reprinted in 30 I.L.M. 847, 852.

449. See S.C. Res. 692, U.N. SCOR, 46th Sess., 2987th mtg., U.N. Doc. S/RES/692 (1991), reprinted in 30 I.L.M. 864. On the work of the Commission, see Ronald J. Bettauer, The United Nations Compensation Commission-Developments Since October 1992, 89 AM. J. INT'L L. 416 (1995); John R. Crook, The United Nations Compensation Commission-A New Structure to Enforce State Responsibility, 87 AM. J. INT'L L. 144 (1993); Hazel M. Fox, Reparations and State Responsibility, in THE GULF WAR 1990-91 IN INTERNATIONAL AND ENGLISH LAW, supra note 319, at 261; Conrad K. Harper, Protecting the Environment During Armed Conflict: The International Community's Effort to Enforce Norms, Remedy Harms, and Impose Accountability, Paper Presented at the Symposium on the Protection of the Environment During Armed Conflict and Operations Other Than War, in NWC SYMPOSIUM PAPERS, supra note 13 (manuscript at 7-9, on file with The Yale Journal of International Law). The current deadline for claims submission is February 1, 1997. See Compensation Commission, Governing Council Decision No. 12, U.N. Doc. S/AC.26/1992/12. The State Department ultimately expects approximately 200 billion dollars in claims to be filed. See Harper, supra at 7.

450. Included within the damage for which Iraq is responsible is that caused as a result of Coalition operations. This approach is premised on the theory that "but for" Iraq's wrongful acts, Coalition operations would never have occurred. The relevant provision provides:

This [responsibility] will include any loss suffered as a result of: (a) Military operations or threat of military action by either side during the period 2 August 1990 to 2 March 1991 ... [and] (c) Actions by officials, employees or agents of the Government of Iraq or its controlled entities during that period in connection with the invasion or occupation.

Compensation Commission, Governing Council Decision No. 7, para. 34, U.N. Doc. S/AC.26/1991/7/Rev. 1, reprinted in UNITED NATIONS, THE UNITED NATIONS AND THE IRAQ-KUWAIT CONFLICT, 1990-1996, at 429, 429 (1996). The actual damage for which the Iraqis will pay includes:

direct environmental damage and the depletion of natural resources as a result of Iraq's unlawful invasion and occupation of Kuwait. This will include losses or expenses resulting from: (a) Abatement and prevention of environmental damage, including expenses directly relating to fighting oil fires and stemming the flow of oil in coastal and international waters; (b) Reasonable measures already taken to clean and restore the environment or future measures which can be documented as reasonably necessary to clean and restore the environment; (c) Reasonable monitoring and assessment of the environmental damage for the purposes of evaluating and abating the harm and restoring the environment; (d) Reasonable monitoring of public health and performing medical screenings for the purposes of investigation and combating increased health risks as a result of the environmental damage; and (e) Depletion of or damage to natural resources.

Id. 
casts the net of liability much more broadly than would have been the case if damages for environmental damage had been based on the law of armed conflict's environmental provisions. The disadvantage of this approach is that an opportunity to clarify the substantive law may have been missed.

Finally, mention should be made of individual responsibility. There is little doubt that environmental damage during armed conflict can form the basis for criminal culpability under the laws of war. In addition, the ILC's Draft Code of Crimes Against the Peace and Security of Mankind provides for trial of "an individual who willfully causes or orders the causing of widespread, long-term and severe damage to the natural environment." 451 This applies during both peace and war but, as indicated in the text, is limited to intentional acts (as opposed to negligent or reckless acts). Though the Draft Code is nonbinding, it certainly enhances the argument that individual responsibility should lie in cases of environmental destruction.

In the Gulf War, however, there was no attempt to impose individual responsibility on Iraqi war criminals. The U.S. Army's War Crimes Documentation Center, given the task of assessing Iraqi actions and gathering evidence of violations, specifically found that individual war crimes had been committed. ${ }^{452}$ In its final report, the Center characterized the Iraqis as having violated both article 23(g) of Hague IV and article 147 of Geneva Convention IV, even though it described the rationale behind the Iraqi destructive acts as "unclear." 453 Noting that criminal responsibility rests with the commander when he orders, permits, or fails to stop offenses of which he knew or should have known, the report was unambiguous when referring to Saddam Hussein:

The evidence collected during this investigation establishes a prima facie case that the violations of the law of war committed against Kuwaiti civilians and property, and against third party nationals, were so widespread and methodical that they could not have occurred without the authority or knowledge of Saddam Husayn. They are war crimes for which Saddam Husayn, officials of the Ba'ath Party, and his subordinates bear responsibility. However, principal responsibility rests with Saddam Husayn. ${ }^{454}$

Submitted to the President of the Security Council in March 1993, the report was subsequently circulated throughout the United Nations. ${ }^{455}$

Why were no charges ever brought if the evidence was so clear? The reasons are primarily practical, not legal. First, it would have been nearly impossible to bring Saddam Hussein and his cohorts to trial. As a result, any proceedings would have to have been held in absentia. Furthermore, the

451. Draft Code of Crimes Against the Peace and Security of Mankind, art. 26, in Report of the International Law Commission on the Work of Its 43d Session, U.N. GAOR, 46th Sess., U.N. Doc. A/46/405, reprinted in 30 I.L.M. 1563, 1593 (1991).

452. See WAR CRIMES DOCUMENTATION CTR., OFFCE OF THE JUDGE ADVOCATE GeN., U.S. ARMY, REPORT ON IRAQI WAR CRIMES (DESERT SHIELD/DESERT STORM) 45-48 (1992) (unclassified version on file at Naval War College Library, Newport, Rhode Island).

453. See id. at 10-11.

454. Id. at 13.

455. See Letter Dated 19 March 1993 from the Deputy Permanent Representative of the United States of America to the United Nations Addressed to the President of the Security Council, U.N. Doc. S/25441 (1993). 
possibility of individual criminal punishment would have made it difficult to negotiate war termination with the Iraqis. Those likely to face criminal proceedings were still in firm control of the country and would not have agreed to truce terms that included their arrest. Finally, the political context at the time was important. That a coalition with membership ranging from Syria to Canada held together at all is surprising. Since the attitude toward legal proceedings varied widely, particularly in the Arab world, convening trials in this postwar environment, which was laden with politics and emotion, might well have ruptured the fragile relations that had been forged. War aims had been deliberately delimited to make possible the coalition's creation. To bring Saddam Hussein to trial would have represented a clear expansion beyond those aims.

Did the absence of trials negatively affect the law of war? In the view of the State Department's Legal Adviser, Conrad Harper, trials would have been untimely:

\footnotetext{
Whether the international community will one day elect to bring to bear the force of criminal sanctions against those who perpetrate gross and unjustified environmental damage in warfare remains to be seen. In my view, we have not yet arrived at the point where the international community is willing to put its credibility, commitment, and the full force of its conscience behind environmental crimes prosecutions in much the same way that it has demanded accountability in the context of Rwanda and Bosnia. ${ }^{456}$
}

If his assessment is correct, and there is no reason to believe it is not, then trials would actually have been a step backward; they would have revealed divisiveness within the international legal community over what the prescriptions actually are. While this might have been a useful exercise from a pedagogical perspective, the environmental protection regime would have been weakened by highlighting the legal fault lines in a politically charged matter.

\section{WHERE TO FROM HERE?}

\section{A. Appraising the Present Law}

By now, there should be little question that the prevailing assessment of the environmental law of war is that it is adequate. In response to those who would argue the contrary by pointing to Iraqi actions in the Gulf, adequacy advocates urge that the problem is enforcement, not law. If only Iraq had complied with the existing law of war, all would have been well. They cite the nearly unanimous condemnation of Saddam Hussein's actions as evidence of universal acceptance of the relevant prescriptive norms.

This school of thought may perhaps reflect a bit of goal orientation. Guided by our justifiable indignation over Hussein's appalling actions, we wanted him to be guilty of war crimes. As members of a predominantly positivist legal culture, we also wanted to be able to point to specific provisions of international law that had been violated. Thus, we looked to the

456. Harper, supra note 449, at 10. 
classic workhorses of the law of war-customary law, Hague law, and Geneva law-and predictably found what we needed. Having embraced this position, logically we have to attribute shortcomings in the application of the environmental law of war to something else. Usually one of two culprits is cited, poor enforcement mechanisms or failure to understand what the prescriptions "really mean."

Based on the analysis set forth above, this position proves less than convincing. The existing environmental law of war neither adequately echoes community values nor serves to foster its aspirations. This body of law poses numerous obstacles to effective legal deterrence of environmental damage during armed conflict, obstacles that have been described at length. They may be grouped into several broadly expressed failings.

First and foremost, if law is to serve the aspirations of the global community, it must be of practical application. Unfortunately, the lack of environmental specificity forces us to fall back upon traditional law of war principles such as necessity and proportionality, even when applying treaty law provisions. These customary prescriptions employ continuums and balancing tests, the manipulation of which is rendered more complex by the inclusion of environmental concerns. Additionally, consider the plethora of uncertainties that stand in the way of practical and consistent application. Is peacetime environmental law applicable in armed conflict? Is the environment a separate value category? If so, should it be measured in an anthropocentric or inherent value context? What weight should be accorded to environmental values? How far should chains of causation stretch? How should the great uncertainty of environmental impact be handled? These and other issues raised throughout this Article are difficult to contemplate in the sterile environment of academia, let alone in the fog of wartime friction. This would be so even in a monocultural context; to expect consistent results across cultures is ambitious, to say the least.

The second problem is that of definitions. Environment-specific treaty law employs the terms "widespread," "long-term," and "severe" in its key provisions. Since these appear to have become the agreed-upon terms of art to be used, one would imagine that they would enjoy a common understanding. However, their meaning has been variously interpreted, for instance, by the U.S. Army, the German Government, the drafters of Protocol I, and ENMOD signatories. This variation complicates application of the environmental law of war.

Finally, the law that does serve to protect the environment lacks internal coherence. Each facet was developed in response to very different problems, in varying contexts, and at different times. No effort has been made to reconcile its various components, or to seek the protective synergism that complementary humanitarian law offers. ${ }^{47}$ In some cases, most notably the definitional quandary just mentioned, this lack of coherence operates to weaken existing prescriptions by muddying the waters. What remains is a body of law that offers only haphazard protection to the environment,

457. As was the intent, for example, in the drafting of Protocol I vis-à-vis the Geneva Convention of 1949. See supra Subsection III.C.3. 
protection characterized by significant gaps.

That the law proper presents problems is clear. But what about the direction in which it is headed? At the outset of this Article, the directional nature of law was highlighted. Is the law on course? Is it moving towards enhancement of world order, or are the trends that have been identified ultimately counterproductive?

While the general vector of the environmental law of armed conflict is correct, it risks going too far. It is absolutely essential that the environment be considered qua environment, not simply as yet another civilian object. This is so because of the unique characteristics that the environment exhibits. In particular, warfare affects nonbelligerents environmentally, either in their own territory or in the global commons. To diminish the water quality of a river, for example, is to harm all of the riparian states, not simply the target state. To spew pollutants into the atmosphere is to render damage elsewhere dependent on the whims of the wind. Environmental damage is often difficult to circumscribe, regardless of the intent of the actor.

The qualitative distinction between environmental and more traditional damage is also demonstrated by the difference in the scope of reverberating effects. Traditional warfare is replete with instances of reverberation, some intentional, some not. Scholars and practitioners may quibble about the severity and proportionality of bombing electrical targets during the Gulf War, for example, but no one would suggest either that its consequences were limited to destruction of the target, or that reverberations were irrelevant to proportionality calculations. Even so, the environment is different, for its very essence is interconnectedness. While it is true that warfare may cause harm beyond the direct application of force, it is difficult for acts of war not to cause such harm to the environment. Moreover, in nonenvironmental damage; the chain of reverberation is usually much shorter; a building is blown up, only to be rebuilt or have its occupants or function move elsewhere. The impact of environmental damage, in contrast, often will play out through many iterations; an effect on one species influences many, a phenomenon which, in turn, repeats itself at each higher level. It is much more pervasive than the traditional damage to which we are accustomed in armed conflict.

Not only is the impact more likely to be cast broadly, but it is also more likely to prove irreversible. There is no way, for example, to recreate a species that has been destroyed. If that species constitutes the primary food source for others, the reverberating effect will be no less harmful to them. The same is true of the many natural resources on which life, human or otherwise, relies. Some means of warfare may have mutagenic effects, and, unfortunately, science is incapable of returning genetic structures to their original states. Finally, and perhaps most importantly, many species that have suffered harm, including humans, can survive if provided sufficient time, space, and resources to do so. Destruction or contamination of an area, however, denies all species both space and resources. Thus, unlike most other damage in warfare, environmental devastation truly may represent crossing the Rubicon of survival.

There is little doubt that the law has moved, albeit slowly and in a very limited way, toward recognizing the uniqueness of the environment and its 
need for special protection. This is apparent in Protocol I and ENMOD's environment-specific provisions, the first such provisions in conventions dealing with armed conflict. It is also evident in the various peacetime instruments that have come into effect over the past several decades and in hortatory and aspirational language found in various nonbinding sources, such as the Stockholm and Rio Declarations. Indeed, even though the Security Council resolutions demanding compensation from Iraq were based on nonenvironmentally related jus ad bellum grounds, the environment was specifically singled out, in and of itself, as a damaged entity generating Iraqi liability.

There is every indication that the law is moving in the right direction. The problem is that it is moving too far. What law is, and how it operates, really depends on the cognitive prism through which it (and the context in which it will be applied) is viewed. These prisms can be thought of as placed along a continuum. Until Vietnam, the environment was not seen as having any independent existence, a view representing one extreme of the continuum. Following that conflict, the environment began to be recognized as a distinct entity, albeit primarily in anthropocentric terms.

Conceptually, anthropocentrism is not a point on the continuum, but rather an area along it within which there are varying degrees and styles of the perspective. For instance, article 55 of Protocol I is framed in terms of "health or survival," whereas the Rio Declaration placed great weight on the interests of developing states. At the limit of anthropocentric environmentalism are those who would weight the environment using measures such as its aesthetic contribution, or perhaps even the sense of placement in the greater scheme of things that it offers humanity. Yet in all of these cases, the human variable is a factor. One may disagree with the precise value that is posited, but at least all valuations are operating from within the same broad context.

The problem is that some would move beyond the limits of anthropocentrism into valuation based on intrinsic worth. An excellent example of this approach is found in Professor Verwey's thoughtful work. A pioneer in identifying the perspectives that have been developed in this Article, Professor Verwey argues for "common recognition" of three principles:

1. the indivisibility of a healthy environment as an indispensable condition for the survival of present and future human generations;

2. the necessity to disconnect the legal protection of the environment in times of armed conflict from its anthropocentric legal enclosure; [and]

3. the need to expand the protective scope of the relevant rules beyond the current level of merely prohibiting known or expectable and directly demonstrable environmental damage. 458

Devotion to the first principle is shared by many anthropocentrics; after all, it is couched in anthropocentric terms. Similarly, the third is a principle of causation more likely to be embraced by intrinsic value advocates, but not

458. Verwey, Protection, supra note 13, at 33. 
exclusively by them. After all, one might want to prohibit environmental damảge that "may" 459 occur because if it does it will affect humans negatively. In contrast, the second principle, at least as stated, ${ }^{460}$ is classic intrinsic valuation. It essentially urges protection of the environment regardless of what it does for humanity. This does not mean that the contribution that the environment makes to humans will be ignored, but that the value of the environment in and of itself will also be considered.

Although it is absolutely clear that anthropocentric approaches of one sort or the other dominate thinking about the impact of war on the environment, there are indications that the law is moving in the intrinsic value direction. The fact that it proved necessary to satisfy both camps by including two environmental provisions in Protocol I demonstrates the degree of support for the approach. Other examples of the degree of support for intrinsic valuation include the menu of options in the proposal offered at the London Conference by Professor Plant, as well as the general tenor of recommendations by organizations such as Greenpeace. ${ }^{461}$

This trend has troubling implications. First, it is one thing to recognize that the environment per se must be protected, and quite another to urge that the environment should be evaluated apart from anthropocentric considerations. In the former case, the uniqueness of the environment is recognized, but the processes of valuation remain relatively intact. Though valuation is more complex when the environment is factored in, anthropocentric valuation not only provides a familiar frame of reference, but it also keeps balancing tests two-dimensional. In purely intrinsic value analysis, in contrast, process and substance are thrown askew. As illustrated in the discussion of customary international law principles, introduction of a third variable necessitates a three-way balancing test among the environment, human values, and military advantage. Furthermore, if human terms are not used to value the environment, what standard should be used? The difficulties of cross-cultural anthropocentric value paradigms pale beside those presented by intrinsic valuation.

In the end, intrinsic valuation leaves us with an incredibly complex process that defies practical application and encourages divisiveness within the community of those who wish to ensure environmental protection during warfare. Well-meaning efforts to enhance protection by recognizing the intrinsic value of the environment will have exactly the opposite result. The flawed prescriptions currently in place will collapse under the weight of attempts to sort through the approach in practice.

There is an even more basic problem with the intrinsic value perspective

459. See id. at $38-40$.

460. Professor Verwey's discussion of the principle includes the concept of per se protection. See $i d$. at 36-37. Indeed, he speaks of the possibility of recognizing the environment as the common heritage of mankind, a particularly anthropocentric characterization. The mere fact that the environment is protected per se does not imply that it is not valued for its anthropocentric character. It simply means that it is considered an independent and unique entity. Whether it is valued intrinsically, anthropocentrically, or in both ways is a separate question.

461. See The Gulf War: Environment as a Weapon, supra note 96, at 220-23 (remarks of Sebia Hawkins of Greenpeace International). 
than determining how to conduct balancing or what weight to attribute to balanced values. Does the international community really want to adopt an approach that would sacrifice human interests to environmental ones? Intrinsic value advocates probably would rush to protest that this is not their intention. But of course it is. Any time one attributes autonomous value to the environment, one risks the possibility that trying to safeguard it will operate at cross purposes with other values. The fact that values conflict is the very raison d'être of balancing tests. Closing territory to military activities may have very real human consequences. Perhaps an attacking force will be forced into an avenue of attack that places the population at greater risk. Maybe environmental restrictions will disallow tactics that would enhance protection of the civilian population. For instance, if smoke that results in extensive collateral damage is the only way to prevent an aerial attack, do we want to deny the tactic to a victimized state with no other means of defending itself?

The issue of sacrificing human values presents itself in two guises. The easier of the two occurs when environmental values are added to the balancing process. Can human values be outweighed by the intrinsic value of the environment? Most reasonable commentators would agree that there are times when humans should be placed at risk to protect the environment. By rejecting intrinsic valuation, the framing of this quite logical assertion in an either/or fashion can be avoided. Viewed anthropocentrically, and very broadly so, the question is not when do human values have to be sacrificed, but rather what are the net human values that will be put into the equation.

A much more disturbing dilemma arises in attempts to determine when the environment should be protected without considering human values at all, that is, without resorting to a balancing test. This is exactly what article 35(3) does; once the level of damage reaches a certain point, the protection kicks in regardless of countervailing human values. Prescriptions crafted in this fashion are extraordinary in that they reject the premise that there are times when human values outweigh environmental ones. For instance, option (a) of the Plant proposal prohibits methods or means of warfare that are intended to, or may, cause any damage to the environment. ${ }^{462}$ This is intrinsic value at its extreme. There is no balancing of any sort, only an absolute prohibition. Yet if failure to acknowledge the environment in and of itself is objectionable, why is it any less objectionable to ignore the human factor? Are humans not as much an integral part of the global ecosystem as plants, other animals, or nonliving resources? What is it that makes us less worthy of protection than the environment's other components? Of course, this perspective represents one extreme of the anthropocentric-intrinsic value continuum, and very few responsible individuals who have considered the issue seriously would go so far. Nevertheless, it does constitute a logical and directional conclusion drawn from the premises underlying the intrinsic value approach.

It is important not to read too much into these criticisms of intrinsic value. First, they are not meant to imply that the environment lacks intrinsic value. Instead, the comments are only designed to highlight the pitfalls associated with decisionmaking processes and standards that incorporate an

462. See supra text accompanying notes $94-95$. 
intrinsic value component. It is unfortunate that intrinsic value cannot easily be folded into balancing processes without generating inconsistent and divisive results, but that inability is an acceptable cost of maintaining the level of protection that the environment and humanity currently enjoy.

Second, the rejection of intrinsic valuation should not be read as suggesting that it is inappropriate to create "absolute" prohibitions-those in which there is no balancing of interests. On the contrary, they can serve as useful short hand for clear-cut cases, or situations of res ipsa loquitur, to borrow from tort law principles. In other words, certain environmental damage (considered anthropocentrically) is so likely to outweigh any potential military advantage that it makes sense to agree upon the prescriptions in advance to facilitate normative clarity and precision. Such prescriptions may be framed in terms of weapons (e.g., persistent chemicals), tactics (e.g., nuclear ground bursts), targets (e.g., nuclear power facilities), or effects (e.g., long-term, widespread, and severe). Furthermore, it is not necessary to establish their prohibitive effect at a damage level above that which traditional legal analysis would yield. This is because the applicative intent of law is designed to foster more than case-specific "right" results. The broader goals of general and specific deterrence require prescriptive systems that are precise and understandable, and that lend themselves to practical enforcement. In isolated cases, right results may have to be sacrificed to secure the overall contributions that absolute prohibitions make to the greater good.

\section{B. What Is To Be Done?}

The proposition that the law is inadequate raises the question of what to do about its deficiencies. Most of the discussion has centered around the desirability of a new law of armed conflict convention to govern environmental damage during warfare. Notable among the proposals have been Professor Plant's model elements and Greenpeace's call for a "Fifth Geneva Convention." The prevailing view, however, is that a convention actually might prove counterproductive. Not surprisingly, those taking this position also generally assert the adequacy of existing prescriptions. If the law is adequate, why take on the daunting task of drafting a new convention?

However, an assertion that the law is insufficient does not necessarily lead to the conclusion that a new treaty is necessary. Two additional issues must be addressed. First, if the law is insufficient, is an international convention the best remedy, or are alternatives such as domestic legislation or the adoption of common military manuals preferable? Second, even if a treaty is the optimal choice, given the current international political and legal context, is the time ripe for the enormous effort that would have to be mounted to secure an effective convention? This Article concludes that a convention is the answer, but that it might prove counterproductive to pursue one aggressively right now.

With regard to the need for an international agreement, it is useful to consider: (1) what the law needs to do, (2) whether those tasks are being accomplished by the existing law, and, if not, (3) whether a treaty would improve matters. For law to be effective, it must deter wrongful conduct. This 
purpose requires clearly enunciated practical norms and the support of the community of nations. Otherwise, states would not know the standards by which their conduct would be measured, nor those to which they should hold others; this scenario would be particularly disruptive to a legal regime which, albeit evolving, generally counsels against interference in the affairs of other states.

Does the present environmental law of war meet these requirements? Without reiterating the many points made throughout this Article, it is fair to say that it falls short. The law is internally inconsistent, unclear, subject to varying definitions, haphazardly generated, and lacks the support of all relevant actors. A convention, on the other hand, could address the issue comprehensively, thereby providing the requisite consistency and clarity. Explicating the environmental conduct expected of states would limit destructive activities by those concerned with remaining within the confines of legality. It also would facilitate condemnation and reaction when rogue states violate the agreed-upon and articulated prescriptions. In particular, it would make it harder for states that might be so inclined to look the other way in the face of violations. The net result would be an increase in the deterrent effect of this body of law.

In terms of practical impact, almost as important would be the existence of an agreed-upon set of norms that could be adopted by the world's armed forces in their military manuals and serve as the basis for substantively common training. This is the purpose of the ICRC Guidelines. Regrettably, the ICRC effort has borne little fruit thus far, an unsurprising fact given the hodgepodge of law to which it had to resort in developing its guidelines. ${ }^{463}$ A comprehensive international convention on the subject presumably would resolve this obstacle. This, in turn, would advance the emergence of a common operational code among armed forces and policymakers.

Despite the advantages of a treaty, admittedly, there would be downsides. Some critics of the idea contend that a treaty is not the appropriate legal instrument to address the topic. For instance, in order to secure agreement, treaties are often subject to declarations, understandings, and reservations. The result is a complicated web of legal relationships that vary based on the parties involved in a particular issue. Indeed, this phenomenon was illustrated in many of the instruments discussed above, such as Protocol I, ENMOD, and the 1925 Gas Protocol. Given the variety of perspectives on the environmental law of war, declarations, understandings, and reservations are likely; the complexity of an already complex subject would thereby swell. Opponents also note that treaties become outdated, whereas customary law, based as it is in state practice, is more adaptive. The pace of scientific discovery exacerbates this distinction, for when dealing with technologically driven agreements there is always the risk that science will outpace their prescriptive utility.

Such arguments are well taken, but not entirely convincing. Even with reservations, a convention almost certainly would be more comprehensive and

463. Another obstacle is the fact that the United States is not a party to one of the ICRC Guidelines' key reference points, Protocol I. 
consistent than the current body of law, composed as it is of everything from custom, to turn-of-the-century agreements that are silent on the issue of the environment, to 1970 s vintage conventions that still are not universally accepted. Moreover, while international agreements can become outdated, once the ground has been broken with the first iteration of a treaty it is easier to update the regime later. ${ }^{464}$ Arguably, then, the risk of becoming dated is outweighed by the benefits that clarity would provide over the life of a treaty. Of course, this assumes that the convention is well done and that it does not create problems such as those raised by Protocol I and ENMOD's terminological schizophrenia. It also assumes that international consensus can be reached on the subject-a major assumption, to say the least.

Despite the usefulness of a convention, is the time right for one? There are very practical reasons to argue that it is not. United States experience with major international treaties has not always been positive. In the cases of both the Law of the Sea Convention and Protocol I, the United States actively participated in negotiations, only to reject what the respective diplomatic conferences produced. Nearly two decades later, the United States is still not a party to either agreement (although this may change with the LOS Convention in the near future). Regardless of the substantive merits of our position, to be the odd man out in these widely accepted treaty regimes certainly is not an enviable position.

Is there any greater likelihood of success in drafting an environmental convention, one with comprehensive norms that are more than hortatory or aspirational, on which all parties can agree? Given the anthropocentric versus intrinsic value and developing versus developed fault lines described earlier, the search for consensus would certainly be challenging. This raises the question of whether it would be preferable to work with the existing prescriptions, accepting their limitations and benefiting from what little common ground does exist. To commence full-fledged negotiations at a point in the development of the law at which normative limits are so unclear and cognitive perspectives so contradictory would be ill advised.

Additionally, the effectiveness of any new convention would be limited by the state of science. As the Gulf War experience made clear, there is much we do not understand about both the effects of war on the environment and its use to harm one's enemies. Is it appropriate to initiate a treaty in an environment of relative ignorance, or would it be better to work with current prescriptions until the quantum and quality of knowledge improve? This is a particularly relevant issue if the goal is to include provisions that address specific means and methods of warfare, rather than abstract descriptions of effect (e.g., widespread, long-term, severe). It will be difficult to reach consensus on weapons, tactics, and targets absent a firmer scientific base than that existing during the Gulf War.

To summarize, we clearly need a convention, and should begin

464. This happened with the Law of the Sea Convention. The U.S. objected to the seabed mining provisions of the treaty. See LOS Convention, supra note 172, pt. XI. Another example is Protocol I, which was designed to update the Geneva Conventions. See Protocol I, supra note 8. While it has proven somewhat difficult to secure universal agreement on Protocol I, the process of securing consensus probably moves as quickly as the evolution of customary principles. 
preparatory work toward formulating a coherent position on its broad parameters. Today we are far enough removed from the emotionalism evoked by the Gulf War environmental destruction to explore rationally the merits and nature of a treaty regime that would respond to contemporary concerns about environmental protection and give warfighters the normative guidance they deserve. Exploratory first steps would force leading states to acknowledge the existing legal shortcomings and begin the process of rectifying them.

That said, at this point in time, the benefits of aggressively pursuing an environmental law of war convention are outweighed by the risk that it would further weaken the inadequate regime that currently exists to protect the environment. Weakening could result from the international political machinations that would attend multilateral negotiations, a possibility compounded by the risks associated with negotiating with a less than robust information base. In order to forge the consensus necessary today, an agreement would inevitably end in highly diluted prescriptions; neither law nor science is sufficiently developed to give the effort a fighting chance.

The belief that this is not a propitious time to take on a major new treaty effort is shared by both the ICRC's Hans-Peter Gasser and Conrad Harper of the State Department, though they do not necessarily embrace the approach taken in this Article to arrive at this conclusion. At the Naval War College Conference, Mr. Gasser argued:

In terms of time, energy and resources, the cost of drafting, negotiating and adopting a new international treaty even on less difficult and controversial issues is today very high indeed. Moreover, failure of a codification attempt may in the end be more harmful to the cause than leaving the law as it is. And there is always the risk that a new treaty may not be ratified by a large number of states. ${ }^{465}$

Speaking at the same conference, Mr. Harper noted:

To the extent that widespread agreement on new laws and standards could be reached-and I have my doubts - the resulting agreement might likely resemble a lowest, common denominator, decidedly unhelpful in dealing with hard cases. Or, in order to garner consensus, a new agreement might well be a model of ambiguity, the value of which could also be fairly questioned. ${ }^{466}$

Given the current state of affairs, both are correct-for the moment.

This analysis raises the question of what can be done now to alleviate the immediate difficulties posed by the existing law. First, it is self-evident that those with influence on the international lawmaking process need to reconsider the off-the-shelf assessment of the law's adequacy. Problems that have been identified need to be worked through in a measured, reflective, and comprehensive fashion. The dialogue must continue to evolve, and the tough issues-anthropocentric versus intrinsic valuation, the contextuality of law, and law's directional and temporal character-have to be faced head on.

In the interim, states can begin addressing the issue individually. Arguably, the United States should seriously reconsider its refusal to ratify Protocol I. Objections to the agreement that were valid in an era of bipolarity

465. Gasser, supra note 355 , at 5-6.

466. Harper, supra note 449 , at 9. 
may no longer be as compelling today. As to the environment, it is true that Protocol I's relevant provisions are less than perfect. Yet in the new global paradigm, the United States needs to be much more concerned about becoming the victim of environmental destruction than about having its operational hands tied by the Convention's prohibitions. This argument is particularly compelling if our concerns extend to the environments of potential allies and if we reflect upon who our likely adversaries might be. Finally, we should not forget that the United States is better able to adjust to limitations on methods and means of warfare than our enemies because of our overwhelming technological superiority, the redundancy of our capabilities, and the quality of the forces with which we are most likely to be allied. These factors give us some leeway in accepting legal regimes that, though imperfect, represent an overall step forward. Simply put, what is needed is a de novo legal and operational net assessment. We need to look at the big picture, not to become trapped in the minutiae.

Unfortunately, measured reflection and reconsideration of our position on international treaties will not solve the warfighters' immediate dilemma, a daunting void of normative guidance. The problem is very real. How should judge advocates advise their commanders? What decision standards should commanders employ when confronted with the prospect that their militarily necessary actions might damage the environment? What can we do to redress the compelling need for uniform and usable guidance?

Obviously, the armed forces must continue to seek a common understanding of the environmental law of war. Positive steps in this direction are apparent throughout the Department of Defense. Sponsorship of the conference at the Naval War College and publication of its proceedings, addition of the subject to the Environmental Law Advanced Course at the Air Force Judge Advocate General School, and devotion of a chapter to the environment in the Army's Operational Law Handbook are all extremely laudable. We need to continue addressing the subject aggressively.

However, the most important and immediate step the United States can take to foster clarity presents itself in the new multiservice law of war manual that is currently being drafted. ${ }^{467}$ Once in place, this single source will set a uniform standard for operations by U.S. forces. Perhaps even more significantly, the manual represents a chance to influence the rest of the world in the development of this area of law. Other armed forces inevitably will follow the U.S. lead. As an example of this tendency, consider Naval Warfare Publication 9, The Commander's Handbook on the Law of Naval Operations. Widely recognized as the most authoritative official source setting forth the naval law of armed conflict, this handbook is kept within arm's reach of the sailors of many nations and serves as their guide to the law of armed conflict. ${ }^{468}$ The new multiservice manual promises to be even more

467. For an excellent analysis of the roles of military manuals, see W. Michael Reisman \& William K. Leitzau, Moving International Law from Theory to Practice: The Role of Military Manuals in Effectuating the Law of Armed Conflict, in THE LAW OF NAVAL OPERATIONS 1 (Naval War College International Law Studies vol. 64, Horace B. Robertson, Jr. ed., 1991).

468. The new Navy manual, NWP 1-14M, supra note 178 , is certain to be as widely adopted as its predecessor, NWP 9. 
influential, particularly in light of the ever-growing leadership role that the United States is playing in international military operations, including MOOTW.

But there is more involved than simply articulating the formal law. Military manuals serve an important function in making law. As Michael Reisman and William Leitzau have noted in their excellent article on the subject, military manuals

are an essential component in the international lawmaking process, often the litmus test of whether a putative prescriptive exercise has produced effective law. Without adequate dissemination, this putative international lawmaking is an exercise in the elaboration of myth through lex simulata rather than the installation of an effective operational code. ${ }^{469}$

In other words, law acquires normative relevance when it becomes internalized, both by the system and by those who are part of it. Systemic internalization is accomplished through acceptance and dissemination of the manual by authoritative military decisionmakers. Individual internalization is fostered by the system's acceptance (military personnel tend to grant the system great deference) and through practice of the norms set forth. Ultimately, an operational code emerges.

Thus, a unique opportunity is at hand, not only to provide our policymakers and warfighters with the legal guidance they require, but also to shape the law itself. Drawing on the analysis presented throughout this Article, and cognizant of the importance of keeping law of war manuals simple (they are designed primarily for warfighters, not lawyers), we can envision the rough outlines of such a manual.

First, the manual's provisions should apply as a matter of policy whenever U.S. forces resort to force, unless the rules of engagement approved by the appropriate authorities (given the political ramifications, most likely the National Command Authorities) indicate otherwise. ${ }^{470}$ Avoiding legal dissection of international versus noninternational armed conflict issues in the manual will avoid confusion by troops in the field. A presumption in favor of international armed conflict standards also will help preclude after-the-fact criticism of U.S. actions. Another topic that should be avoided in the manual is the applicability of peacetime law. Its prescriptions are simply too uncertain, and its applicability too complex, for it to be incorporated directly into a usable law of war manual at this time. ${ }^{471}$

The applicability of general customary law principles such as necessity, proportionality, and humanity to environmental damage merits particular

469. Reisman \& Leitzau, supra note 467 , at 1 .

470. The Army's current position is that the 1993 Chemical Weapons Convention is not generally applicable to MOOTW. However, U.S. policy limiting the uses of chemicals to those set forth in Executive Order 11,850 for riot control agents would apply to MOOTW. See OPERATIONAL LAW HANDBOOK, supra note 179, at 5-5; see also supra notes 427-28 and accompanying text.

471. A caveat that peacetime law may be applicable to the extent it is consistent with the law of armed conflict could be included as a footnote if an annotated version is produced (as is being done with NWP 1-14M, supra note 178). The ICRC Guidelines provide an example of how such a provision might read: "International environmental agreements and relevant rules of customary law may continue to be applicable in times of armed conflict to the extent that they are not inconsistent with the applicable law of armed conflict." ICRC Guidelines, supra note 149, para. 5. 
emphasis in the manual. Given the confusion it has generated, the concept of military necessity needs to be clarified by pointing out that it is a prerequisite to legality, not a device to excuse deviations from environmental norms. ${ }^{472}$ For the sake of clarity, it should also be pointed out that all of the prohibitions extend to the global commons (e.g., the high seas). Similarly, "property" and "civilian objects" are best defined as including res communes, such as air.

Also deserving emphasis is the concept of protection of the environment per se. This can be done by including a separate section on the environment or adding qualifiers at appropriate places in the text. Despite the need to address the environment as an independent entity, careful draftsmanship is required to avoid creating the impression that an intrinsic value approach is being adopted. Just because the environment deserves to be singled out for protection does not imply that it should be valued intrinsically instead of anthropocentrically.

Indeed, special care must be taken not to incorporate, even unintentionally, intrinsic value concepts. This is most likely to be done through the inclusion of absolute prohibitions. To minimize this possibility, it is best to articulate prohibitions in terms of weapons, tactics, or targetsnot results or effects. All absolute prohibitions present some risk. They are essentially a form of legal shorthand that supplants the need to do proportionality calculations in situations analogous to res ipsa loquitur. By their very nature, there will be times when absolute prohibitions preclude an action that would otherwise be acceptable. That is the cost of having them. Depending on how they are written, there is even a risk that their application, by operating outside human concerns, actually would lower the level of protection provided to humans. To avoid this unacceptable result, a provision could be included in the manual to the effect that an absolute prohibition does not apply if, using the Protocol I, article 55 language, the prohibition would unacceptably heighten the risk to human health and survival.

Target-based prohibitions should include the Protocol I ban on attacking "objects indispensable to the civilian population" when the purpose is to deny those objects to the civilian population. Since the United States supports this Protocol I prohibition, it is reasonable to state it in the absolute. ${ }^{473}$ As a matter of policy, the manual should also include the Convention's prohibition on attacking works containing dangerous forces. This would represent only a minor limitation on U.S. operations, for it would be the exceptional case in which the benefits of attacking them would outweigh the political costs of doing so. Nevertheless, since the prohibition would be policy-based, an exception for NCA-approved strikes is advisable.

Weapons-specific prescriptions found in international law (e.g., the Chemical Weapons Convention when ratified) and U.S. policy pronouncements (e.g., Executive Order 11,850) are equally necessary. In light

472. The ICRC Guidelines correctly state the standard: “Destruction of the environment not justified by military necessity violates international humanitarian law. . . . The general prohibition to destroy civilian objects, unless such destruction is justified by military necessity, also protects the environment." ICRC Guidelines, supra note 149, paras. 8-9.

473. The technique is considered a form of starvation. See DEPLOYMENT DESKBOOK, supra note 318, tab 12, paras. 1.8.5-1.8.5.1. 
of the political implications deriving from Protocol III to the Conventional Weapons Convention, the use of incendiaries against environmental targets should be prohibited as a matter of policy except when employed against a target that is a military objective clearly separated from concentrations of civilians, ${ }^{474}$ or when otherwise authorized in rules of engagement approved by appropriate authorities. Given the political risks, it would be reasonable to designate the NCA as the appropriate authority, though this power could be delegated.

Since not all possible weapons, tactics, and targets could possibly be addressed in the manual, it will be necessary to incorporate some result-based prohibitions. As a general rule, they should contain such caveats as suggested above. Of course, the most compelling dilemma regarding such prescriptions is whether to adopt the "widespread, long-standing, and/or severe" formula. This formula should be adopted. It is clearly the prevailing standard: It is found in both of the binding instruments directly on point, Protocol I and ENMOD, as well as in publications such as the ICRC Guidelines and the German manual. The only potential alternative is the "due regard" criterion offered in NWP $1-14 \mathrm{M}^{475}$ and the San Remo Manual. ${ }^{476}$ While it may make sense to employ this maritime standard of care in the naval context, it is not widely accepted as a standard in land warfare, nor is there any firm basis for its use in existing environmental law of war. Additionally, it is questionable whether due regard adds much beyond traditional customary international law principles; even if it did, it is a standard that invites subjective interpretation. For better or worse, "widespread, long-standing, and/or severe" is the standard of choice in the international community. Therefore, the United States should adopt it as its own and direct its efforts at securing consensus on a suitable definition.

Working towards a common understanding is the key. Since the standard is ill-defined, the fashion in which the manual unravels the definitional maze will prove very influential. How might it do so? To begin with, when speaking of manipulating environmental processes as a weapon, the definitions should be drawn from the ENMOD Understanding. After all, that particular component of the legal regime is relatively settled. However, what of damage to the environment? An excellent approach is that adopted by the Army in defining the Protocol I terms in its Operational Law Handbook. "Long-term" is measured in decades (twenty or thirty years), a definition that enjoys the support of most practitioners and scholars because it is viewed as comporting with the original intent of the drafters. Since there is no indication of what was meant by the term "widespread" in the Protocol I drafting process, it makes sense to defer to its sole legal definition, that of ENMOD. Though ENMOD definitions were specifically said not to bind other agreements, this does not negate the logic of using them to minimize confusion if doing so makes sense contextually. Thus, as the Army does, the new manual should

3.

474. The Protocol allows use in this circumstance. See Protocol III, supra note 134, art. 2, para.

475. See supra note 178.

476. See supra note 171. 
describe the term as implying damage that extends to several hundred kilometers. With regard to "severe," the Handbook refers to the "prejudices the health or survival of the population" language of article $55 .{ }^{477}$ While it certainly is essential to include damage at this level, ENMOD's definition is more comprehensive. As noted, "severe" was defined in the Understanding related to article I as "involving serious or significant disruption to human life, natural and economic resources or other assets," a definition that encompasses "health and survival," but also has the advantage of extending to "property." 478 Extension of the definition in this manner is consistent with Protocol I protections generally, and with the international law of armed conflict more broadly.

Except when restating the ENMOD prohibition, the phrase "widespread, long-term, and severe" should be cast in the conjunctive. To do otherwise would set an excessively high level of protection. It would be illogical to forbid absolutely an action that caused long-term and widespread environmental damage if that damage were insignificant. Similarly, if the damage were long-term and severe, but isolated, an absolute ban would constitute overreaching. A better result would be achieved through simple proportionality analysis.

Finally, inclusion of a section on responsibility is advisable, though care must be taken not to overstate the case. Individual responsibility could be addressed by noting that breach of the manual's provisions may constitute a violation of the Uniform Code of Military Justice and, in certain cases, amount to a war crime. A provision on state responsibility should point out that states may be held responsible for the acts of their military forces, and that obligations owed under international law to nonbelligerents generally remain in effect during armed conflict.

Hopefully, these suggestions will offer food for thought as the effort to craft the new law of war manual gains momentum. Whatever the outcome, the drafters must understand the great opportunity and responsibility that the task presents. There is probably no endeavor currently underway anywhere having a greater potential for shaping the environmental law of the future.

\section{CONCLUSION}

After all is said and done, the assertion that the present environmental law of war is adequate does not hold water. It is an imprecise law, full of gaps and competing perspectives. The present standards are simply not sufficiently robust to survive the hostile environment of international relations. Indeed, even after the Gulf War, a case involving near-universal condemnation of the resulting environmental destruction, the basis for state responsibility was found elsewhere. This should be of enormous concern to those who value the environment.

Despite its shortcomings, the time is not ripe for a top-to-bottom reworking of the law. We first have to admit that we have a

477. See supra note 337 and accompanying text.

478. See supra note 395 and accompanying text. 
problem-acknowledge that the emperor has no clothes, if you will-and then we must attempt to better our understanding of the problem. To do that, it is necessary to identify legal trends and uncover the law's motivating forces. If we are ever to develop a consensus, we must also grasp the varying cognitive prisms through which the topic is viewed. Hopefully, this Article has contributed to the crucial dialogue that must precede further progress in the field.

Finally, we must understand that this is not an ivory tower exercise for theorists who roam the halls of academia. On the contrary, the environment affects us all in ways that we are only beginning to comprehend. Just as important, the issue has real-world operational implications for commanders in the field. They deserve guidance that is clear, comprehensive, and practical. In the end, this is what the entire discussion has been about-giving warfighters the tools they require to safeguard the values of the global community effectively. If this Article has contributed in any way to that end, then the time and effort expended will have been very well rewarded indeed. 
